\title{
FERNANDA SHIMABUKURO
}

\section{Avaliação in vitro da cisplatina, em linfócitos de pacientes com melanoma cutâneo, por meio de testes citogenéticos}

Dissertação apresentada à Faculdade de Medicina da Universidade de São Paulo para obtenção do título de Mestre em Ciências

Programa de Fisiopatologia Experimental

Orientadora: Prof. Dra. Gilka J. Fígaro Gattás

São Paulo

2010 
Dados Internacionais de Catalogação na Publicação (CIP)

Preparada pela Biblioteca da

Faculdade de Medicina da Universidade de São Paulo

Creprodução autorizada pelo autor

Shimabukuro, Fernanda

Avaliação in vitro da cisplatina, em linfócitos de pacientes com melanoma cutâneo, por meio de testes citogenéticos / Fernanda Shimabukuro. -- São Paulo, 2010.

Dissertação(mestrado)--Faculdade de Medicina da Universidade de São Paulo. Programa de Fisiopatologia Experimental.

Orientadora: Gilka J. Fígaro Gattás.

Descritores: 1.Melanoma 2.Cisplatina 3.Teste do cometa 4.Reparo do DNA 5.In vitro

USP/FM/DBD-180/10 
"Sometimes you're ahead, sometimes you're behind.

The race is long and, in the end, it's only with yourself."

Mary Schmich, Wear Sunscreen, 1997. 


\section{DEDICATÓRIA}

Aos meus pais, por todo amor, apoio e incentivo em todos os momentos de minha vida, pelos exemplos que são e por todas as oportunidades que eles me proporcionam.

Aos meus irmãos: Alessandro, Vanessa e Leandro, por todo incentivo, companheirismo e amizade.

Ao Guilherme, por todo amor, carinho, incentivo e paciência durante essa etapa de minha vida. 


\section{AGRADECIMENTOS}

À Profa. Dr ${ }^{a}$. Gilka Gattás, Livre Docente do Departamento de Medicina Legal, Ética Médica, Medicina Social e do Trabalho da Faculdade de Medicina da Universidade de São Paulo (FMUSP), pela orientação neste trabalho e por todos os seus ensinamentos.

À Fundação de Amparo à Pesquisa do Estado de São Paulo (FAPESP), pela concessão da bolsa de mestrado, que me permitiu a realização deste trabalho.

Ao Prof. Dr. Cyro Festa Neto e ao Prof. Dr. José Antônio Sanches Jr., Livre Docentes do Departamento de Dermatologia da FMUSP, e à Clínica de Dermatologia do Hospital das Clínicas da Faculdade de Medicina da Universidade de São Paulo (HCFMUSP), pela colaboração para que esta pesquisa pudesse ser realizada.

Aos pacientes e indivíduos controles, que aceitaram participar do estudo e foram essenciais para a realização do mesmo. À Fundação Pró-Sangue Hemocentro de São Paulo pela colaboração nas coletas do material.

A minha madrinha, tia Sônia Maria Arashiro Tamasiro, bacharel em Letras pela FFLCH-USP, pela valiosa correção da redação da dissertação e por todo apoio.

Ao técnico do laboratório, Marcelo Fernando do Nascimento, pela ajuda na coleta do material e pela amizade.

À Deise Crispim, companheira de Citogenética, pela ajuda nos experimentos e pela amizade. 
À Dra. Fernanda de Toledo Gonçalves, Pesquisadora Científica do LIM 40, por toda ajuda no laboratório, pelas sugestões e discussões referentes ao tema do trabalho, e principalmente, pela amizade e apoio desde que ingressei no laboratório.

Às amigas de laboratório, por todo o incentivo e apoio, mas principalmente pela amizade e convivência do dia a dia.

Ao LIM 40 do Departamento de Medicina Legal, Ética Médica, Medicina Social e do Trabalho pelo apoio financeiro concedido para a realização da parte experimental da pesquisa.

À Faculdade de Medicina da Universidade de São Paulo e ao Programa de Pós-Graduação em Fisiopatologia Experimental.

A todas as pessoas, que contribuíram de alguma forma para a realização deste trabalho.

A Deus, sempre.

MUITO OBRIGADA 


\section{SUMÁRIO}

Lista de abreviaturas

Lista de tabelas

Lista de figuras

Resumo

Summary

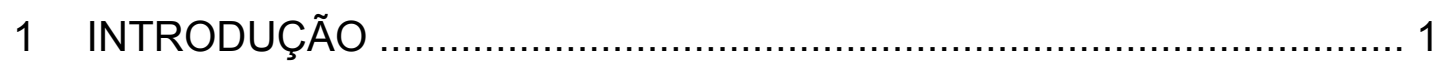

1.1 Características do Melanoma Cutâneo .......................................... 3

1.2 Fatores de Risco do Melanoma .................................................. 5

1.3 Mecanismos de Dano ao DNA por Exposição aos Raios UV ........... 6

1.3.1 Mecanismos de Reparo do DNA à Exposição aos UV .......... 8

1.4 Tratamento do Melanoma .................................................... 11

1.5 Testes Citogenéticos ........................................................... 17

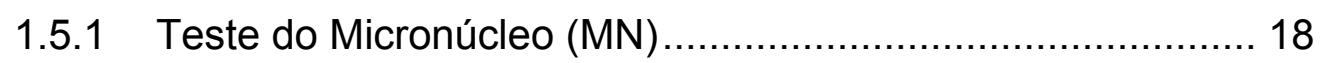

1.5.2 Teste do Cometa ................................................. 20

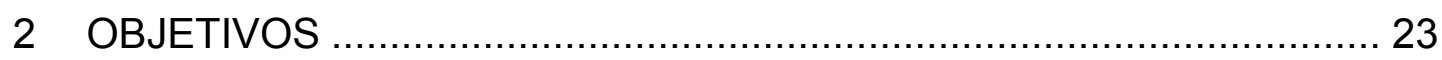

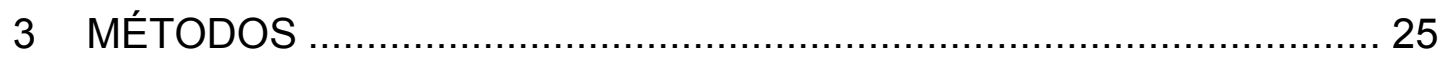

3.1 Casuística ....................................................................... 26

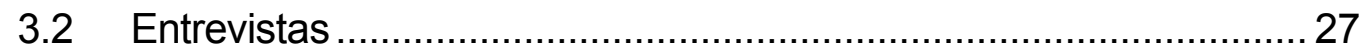

3.3 Testes Citogenéticos e Critérios de Análise.................................. 28

3.3.1 Teste do MN ........................................................ 28

3.3.2 Teste do Cometa ...................................................... 31

3.4 Análise Estatística ........................................................... 39

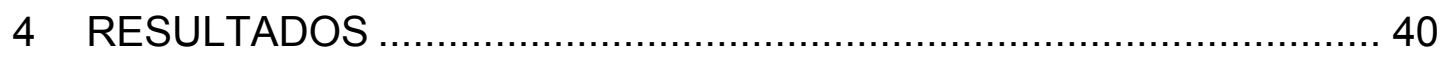

4.1 Caracterização da População do Estudo ..................................... 41

4.2 Caracterização do Tumor nos Pacientes com Melanoma ............... 44

4.3 Testes Citogenéticos ......................................................... 45

4.3.1 Teste do MN ........................................................... 45

4.3.2 Teste do Cometa .................................................... 48

4.3.3 Associação dos testes do MN e do Cometa: ...................... 58 


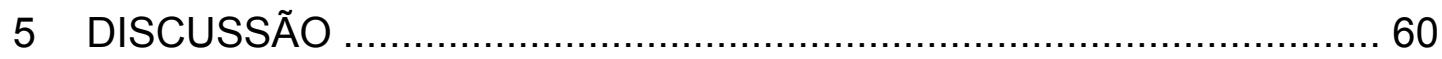

5.1 Caracterização dos Grupos Estudados ....................................... 61

5.2 Avaliação Citogenética ................................................................. 63

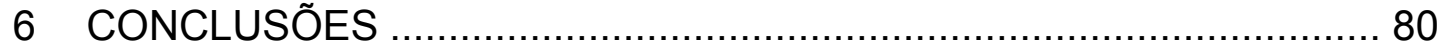

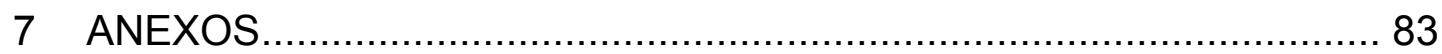

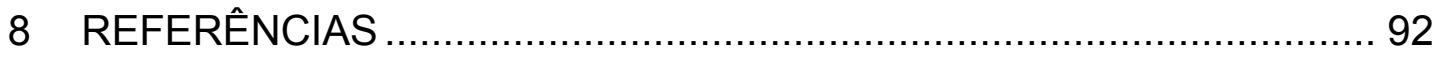




\section{LISTA DE ABREVIATURAS}

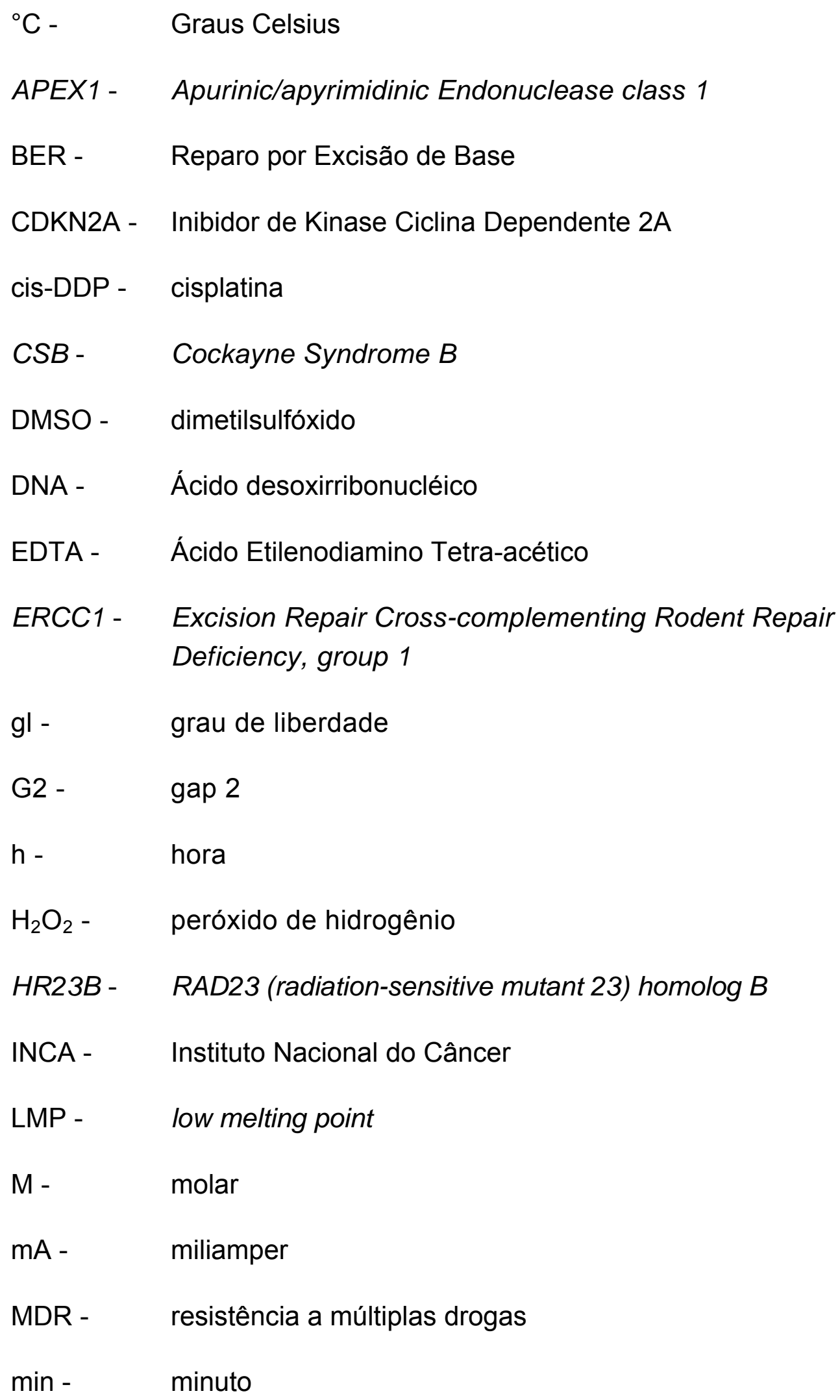




\begin{tabular}{|c|c|}
\hline MGE - & microgel electrophoresis \\
\hline $\mathrm{mg} / \mathrm{m}^{2}-$ & miligramas por metro quadrado \\
\hline $\mathrm{mL}$ - & mililitros \\
\hline $\mathrm{mm}-$ & milímetros \\
\hline MMR - & Mismatch Repair \\
\hline $\mathrm{MN}-$ & micronúcleo \\
\hline NER - & Reparo por Excisão de Nucleotídeo \\
\hline $\mathrm{nm}-$ & nanômetros \\
\hline OGG1 - & 8 - oxoguanine glycosylase \\
\hline PBS - & Phosphate buffered saline \\
\hline RNA - & Ácido ribonucléico \\
\hline ROS - & Espécie Reativa de Oxigênio \\
\hline rpm - & rotações por minuto \\
\hline RPMI - & Roswell Park Memorial Institute \\
\hline SCG - & single cell gel assay \\
\hline UV - & Ultravioleta \\
\hline UVA - & Ultravioleta A \\
\hline UVB - & Ultravioleta B \\
\hline V - & volume \\
\hline$X P$ - & Xeroderma Pigmentoso \\
\hline$X P C-$ & Xeroderma Pigmentosum C \\
\hline$X P D-$ & Xeroderma Pigmentosum D \\
\hline$X P F-$ & Xeroderma Pigmentosum F \\
\hline
\end{tabular}


XRCC1 - X-ray repair complementing defective repair in Chinese hamster cells 1

XRCC2 - $\quad X$-ray repair complementing defective repair in Chinese hamster cells 2

XRCC3 - $\quad$ X-ray repair complementing defective repair in Chinese hamster cells 3

$\mu g$ - $\quad$ micrograma

$\mu \mathrm{L}-\quad$ microlitro

$\mu \mathrm{M}-\quad$ micromolar 


\section{LISTA DE TABELAS}

Tabela 1: Distribuição dos pacientes com melanoma e controles de acordo com o sexo, idade, características fenotípicas, hábitos de bebida e fumo, sensibilidade à exposição solar e história de câncer na família

Tabela 2: Distribuição das características histopatológicas do tumor de pacientes com melanoma, segundo a classificação de Clark e índice de Breslow.

Tabela 3: Sexo, idade e frequência de linfócitos binucleados com $\mathrm{MN}$ observada nos pacientes $(P)$ com melanoma e nos controles $(C)$..46

Tabela 4: Frequência de células binucleadas com MN observada nos pacientes com melanoma e no grupo controle

Tabela 5: Distribuição dos 20 pacientes com melanoma quanto ao sexo, idade e frequência de Cometas revelado pelo escore final das culturas sem tratamento (dano basal), culturas tratadas com $\mathrm{H}_{2} \mathrm{O}_{2}(30 \mathrm{~V})$ por uma hora (controle positivo) e culturas tratadas com $\mathrm{H}_{2} \mathrm{O}_{2}(10 \mu \mathrm{M})$ por 5 minutos além dos tratamentos, in vitro, com cisplatina em três concentrações diferentes $(10 \mu \mathrm{M}, 100 \mu \mathrm{M}$ e $250 \mu \mathrm{M})$.

Tabela 6: Distribuição dos 19 indivíduos controle quanto ao sexo, idade e frequência de Cometas revelado pelo escore final das culturas sem tratamento (dano basal), culturas tratadas com $\mathrm{H}_{2} \mathrm{O}_{2}$ (30V) por uma hora (controle positivo) e culturas tratadas com $\mathrm{H}_{2} \mathrm{O}_{2}(10 \mu \mathrm{M})$ por 5 minutos além dos tratamentos, in vitro, com cisplatina em três concentrações diferentes $(10 \mu \mathrm{M}, 100 \mu \mathrm{M}$ e $250 \mu \mathrm{M})$

Tabela 7: Comparação da média dos escores avaliados pelo teste do Cometa em linfócitos de 20 pacientes e 19 indivíduos controle após exposição in vitro a $10 \mu \mathrm{M}, 100 \mu \mathrm{M}$ e $250 \mu \mathrm{M}$ de cisplatina e reparo do DNA, sem a droga, por $1 \mathrm{~h}, 2,5 \mathrm{~h}$ e $5 \mathrm{~h} \mathrm{.....53}$ 
Tabela 8: Análise de comparações múltiplas de Tukey (147 gl) para o teste do Cometa entre os valores do dano basal, observados em linfócitos de pacientes com melanoma e indivíduos controle, e os tempos de reparo ( $1 \mathrm{~h}, 2,5 \mathrm{~h}$ e $5 \mathrm{~h}$ )

Tabela 9: Análise de comparações múltiplas de Tukey (147 gl) para o teste do Cometa entre os valores do tratamento com cisplatina, observados em linfócitos de pacientes com melanoma e indivíduos controle, e os tempos de reparo ( $1 \mathrm{~h}$, $2,5 \mathrm{~h}$ e $5 \mathrm{~h})$

Tabela 10: Análise de comparações múltiplas de Tukey (169 gl) para o teste do Cometa entre os valores do dano basal, considerando-se em conjunto os resultados observados nos pacientes e indivíduos controle, quanto aos tratamentos com cisplatina $(10 \mu \mathrm{M}, 100 \mu \mathrm{M}$ e $250 \mu \mathrm{M})$ e em diferentes tempos de reparo $(1 \mathrm{~h}, 2,5 \mathrm{~h}$ e $5 \mathrm{~h})$

Tabela 11: Sexo, idade e frequência de linfócitos binucleados com MN e de Cometas (dano basal sem tratamento) observada nos pacientes $(P)$ com melanoma

Tabela 12: Sexo, idade e frequência de linfócitos binucleados com $\mathrm{MN}$ e de Cometas (dano basal sem tratamento) observada nos controles (C) sem melanoma 


\section{LISTA DE FIGURAS}

Figura 1: Representação esquemática de estruturas químicas de dímeros de pirimidina que se formam na molécula de DNA após exposição aos raios UV.

Figura 2: Representação da estrutura química da cisplatina (cisdiaminodicloroplatina (II) ou cis-DDP).

Figura 3: Representação esquemática dos adutos cisplatina-DNA incluindo crosslink intra-fita (a), crosslink inter-fita (b) e aduto monofuncional (c).

Figura 4: Esquema das etapas envolvidas no reparo do crosslink 1,2 intra-fita pelo sistema de reparo por excisão de nucleotídeos (NER).

Figura 5: Linfócitos de sangue periférico após serem estimulados à divisão, in vitro, são impedidos de fazer a divisão citoplasmática na presença de citocalasina B. Células binucleadas sem MN (a) ou com MN (b) são consideradas na análise citogenética.

Figura 6: Representação de um linfócito de sangue periférico binucleado obtido após a adição de citocalasina B em cultura, sem (a) e com micronúcleo (b). Fotos referentes a culturas analisadas de pacientes com melanoma e controles.

Figura 7: Representação esquemática dos procedimentos utilizados no teste do Cometa, realizado com linfócitos de sangue periférico de pacientes com melanoma e indivíduos controle.

Figura 8: Representação esquemática dos tratamentos realizados em linfócitos de sangue periférico de pacientes com melanoma e controles, totalizando quinze microtubos por indivíduo.

Figura 9: Fotos de Cometas visualizados nas culturas analisadas, de pacientes com melanoma e controles, de acordo com a classificação de danos no DNA (aumento de 40x).

Figura 10: Médias dos escores do Cometa do grupo controle e dos pacientes com melanoma em diferentes tempos e concentrações da cisplatina. o dano basal corresponde aos linfócitos sem tratamento com cisplatina. 


\section{RESUMO}

Shimabukuro F. Avaliação in vitro da cisplatina, em linfócitos de pacientes com melanoma cutâneo, por meio de testes citogenéticos [dissertação]. Faculdade de Medicina, Universidade de São Paulo. 109p.

O melanoma cutâneo maligno é uma lesão neoplásica originada nos melanócitos epidérmicos, sendo altamente invasiva e agressiva, com elevada taxa de mortalidade, cuja incidência vem aumentando nos últimos anos. O tratamento do melanoma é cirúrgico e os pacientes com metástase podem receber quimioterapia com cisplatina que ao formarem adutos com o DNA alteram o processo de replicação da célula cancerosa. Sugere-se que os sistemas de reparo do DNA tenham um papel importante na etiologia do melanoma (reparo deficiente) e no tratamento do mesmo (eficiente eliminação dos adutos). A identificação prévia da resposta dos pacientes com melanoma ao tratamento com cisplatina pode ser um indicador biológico importante na clínica oncológica. O presente trabalho teve como objetivo, a partir de linfócitos de sangue periférico de pacientes com melanoma e de controles, avaliar o dano no DNA antes e após a adição, in vitro, de cisplatina $(10 \mu \mathrm{M}, 100 \mu \mathrm{M}$ e $250 \mu \mathrm{M})$, além de estimar a capacidade de reparo do DNA, após a retirada da droga (1h, 2,5h e $5 \mathrm{~h}$ ). Foram utilizados os testes do micronúcleo (MN - dano basal) e do Cometa (dano basal, ação da cisplatina e reparo do DNA). A análise citogenética foi possível em 20 pacientes com melanoma (10 homens e 10 mulheres, média de 50,6 $\pm 5,9$ anos) e 19 controles ( 9 homens e 10 mulheres, média de 49,9 \pm 5,5 anos) que também responderam a um questionário sobre hábitos e tipos de exposição a fatores de risco ao melanoma. A frequência do dano basal pelo teste do MN e do Cometa em linfócitos de pacientes $(M N=1,2 \pm 1,2$ e Cometa $=59,3 \pm$ $62,5)$ foi praticamente o dobro da observada nos controles $(\mathrm{MN}=0,6 \pm 1,0 \mathrm{e}$ Cometa $=35,3 \pm 18,6$ ) embora a diferença entre os grupos, em ambos os testes, não tenha sido considerada estatisticamente significante ( $p=0,23$ e $p=0,85$, respectivamente). $O$ tratamento in vitro com cisplatina, em comparação com o dano basal, aumentou a frequência de Cometas nas três concentrações estudadas $(10 \mu \mathrm{M}, 100 \mu \mathrm{M}$ e $250 \mu \mathrm{M})$ tanto para os pacientes $(65,50 \pm 50,06,72,74 \pm 50,89$ e $77,26 \pm 44,16)$ quanto para os controles $(66,53 \pm 49,85,66,53 \pm 26,33$ e $81,74 \pm 43,12)$ diferença esta considerada significante somente para o grupo controle, nas três concentrações avaliadas ( $p=0,0175, p=0,0002$, e $p=0,0002$, respectivamente). Quanto aos diferentes tempos de reparo (1h, 2,5h e $5 \mathrm{~h}$ ), após a retirada de cisplatina nas diferentes concentrações estudadas, verificou-se aumento na frequência média de Cometas tanto para os pacientes com melanoma $(93,88 \pm 33,7$, $101,75 \pm 35,7$ e $99,31 \pm 32,30)$ quanto para os controles $(92,45 \pm 38,4$, $100,82 \pm 38,8$ e $100,81 \pm 31,7)$, diferença que foi estatisticamente significante quando comparada ao dano basal observado nos pacientes $(p<0,001)$ e nos controles $(p<0,001)$. Resultados semelhantes foram observados quando comparados em conjunto os escores dos tempos de reparo com o escore obtido após tratamento com cisplatina nos pacientes $(71,09 \pm 48,2 ; p \leq 0,005)$ e nos controles $(71,59 \pm 40,5 ; p \leq 0,005)$. Os resultados obtidos parecem 
indicar um padrão de resposta semelhante em relação à cisplatina e ao reparo do DNA nos dois grupos de indivíduos avaliados. O período de incubação das células, após a retirada da cisplatina, bem como o número de indivíduos avaliados podem ter influenciado nos resultados obtidos. Por outro lado, a resposta observada nos linfócitos in vitro, pode não ser representativa do efeito in vivo da célula tumoral. Entretanto, a identificação de marcadores de resposta a tratamentos com quimioterápicos, a partir de linfócitos de sangue periférico pode ser uma estratégia de pesquisa importante na prática clínica, inclusive para o melanoma.

Descritores: 1.Melanoma 2.Cisplatina 3.Teste do Cometa 4.Reparo do DNA 5. in vitro 


\section{SUMMARY}

Shimabukuro F. In vitro assessment of cisplatin, in lymphocytes of patients with cutaneous melanoma, using cytogenetic tests [dissertation]. "Faculdade de Medicina, Universidade de São Paulo. 109p.

Cutaneous melanoma is a malignant tumor originated from epidermal melanocytes, highly invasive and aggressive, with high mortality, and incidence that has been increasing over the years. The treatment for melanoma is surgery and patients with metastasis may receive chemotherapy with cisplatin, that results in DNA adducts that alters the replication process in cancer cells. It is suggested that the DNA repair systems have an important role in the etiology of melanoma (risk due to deficient repair) and treatment efficiency (removal of DNA adducts can decrease the treatment results). The prior identification of the response of melanoma patients to treatment with cisplatin may be an important biological marker in clinical oncology. The aim of this study was to assess, in peripheral blood lymphocytes from melanoma patients and controls, the DNA damage before and after the addition of cisplatin $(10 \mu \mathrm{M}, 100 \mu \mathrm{M}$ and $250 \mu \mathrm{M})$, in vitro, and estimate the capacity of DNA repair after drug removal (1h, 2.5h and $5 \mathrm{~h}$ ). The micronucleus test ( $\mathrm{MN}$ - basal DNA damage) and the Comet assay (basal DNA damage, action of cisplatin and DNA repair) were used for the evaluation. Cytogenetic analysis was performed in 20 melanoma patients (10 men and 10 women, average age $50.6 \pm 5.9$ years old) and 19 controls ( 9 men and 10 women, average age $49.9 \pm 5.5$ years old) who also answered a questionnaire on habits and types of exposure to risk factors for melanoma. The frequency of basal DNA damage by the MN test and the Comet assay in lymphocytes from patients $(\mathrm{MN}=1.2 \pm 1.2$ and Comet $=59.3 \pm 62.5)$ was nearly twice the observed in controls $(\mathrm{MN}=0,6 \pm 1.0$ and Comet $=35.3 \pm$ 18.6), although the difference between the groups in both tests was not considered statistically significant $(p=0.23$ and $p=0.85$, respectively). The in vitro treatment with cisplatin, compared with the basal DNA damage, increased the frequency of Comets in the three studied concentrations $(10 \mu \mathrm{M}, 100 \mu \mathrm{M}$ and $250 \mu \mathrm{M})$ for patients $(65.50 \pm 50.06,72.74 \pm 50.89$ and $77.26 \pm 44.16)$ and for the controls $(66.53 \pm 49.85,66.53 \pm 26.33$ and $81.74 \pm$ 43.12) and the difference was statistically significant only for the control group, for all cisplatin concentrations $(p=0.0175, p=0.0002$ and $p=0.0002$, respectively). Considering the different repair times ( $1 \mathrm{~h}, 2.5 \mathrm{~h}$ and $5 \mathrm{~h}$ ), after removal of cisplatin at different concentrations, there was an increase in the mean frequency of Comets for both melanoma patients (93.88 $\pm 33.7,101.75$ \pm 35.7 and $99.31 \pm 32.30)$ and for the controls $(92.45 \pm 38.4,100.82 \pm 38.8$ and $100.81 \pm 31.7$ ), and the difference was statistically significant when the repair Comet score was compared to the basal DNA damage observed in patients $(p<0.001)$ and controls $(p<0.001)$. Similar results were observed when the Comet scores of repair times were compared to the Comet scores obtained after treatment with cisplatin in patients $(71.09 \pm 48.2, p \leq 0.005)$ and controls $(71.59 \pm 40.5, p \leq 0.005)$. The results seem to indicate a similar pattern of response to cisplatin and DNA repair in both groups of subjects 
evaluated. The period of incubation of the cells after cisplatin removal and the number of individuals studied may have influenced the results. The lymphocytes' response, in vitro, to cisplatin may not be representative of the in vivo effect of tumor cell. However, the identification of markers of response to treatment with chemotherapy from peripheral blood lymphocytes may be an important research strategy in clinical practice, including melanoma.

Descriptors: 1.Melanoma 2.Cisplatin 3.Comet Assay 4.DNA Repair 5.in vitro 


\section{INTRODUÇÃO}


O melanoma cutâneo maligno é uma lesão neoplásica oriunda de melanócitos epidermais (Maddodi e Setaluri, 2008). É um câncer altamente invasivo e agressivo, com elevada taxa de mortalidade, que resulta de interações de fatores genéticos e ambientais (Winsey et al., 2000, Slominski et al., 2001). A incidência e mortalidade do melanoma estão em ascensão em todo o mundo (Dadras et al., 2005, Rigel, 2008) e é previsto que continue a crescer como resultado de uma redução contínua da concentração do ozônio estratosférico (Wei et al., 2003). Para 2010, foram previstos 2.960 casos novos em homens e 2.970 casos novos em mulheres segundo as estimativas de incidência de câncer no Brasil (INCA, 2009). Os maiores índices de melanoma ocorrem em áreas próximas ao Equador e com elevadas altitudes, no entanto, tais índices também podem variar de acordo com a pigmentação da pele e com os padrões de exposição solar em dada população (Stahl et al., 2004, Rigel, 2008). A sobrevida média estimada em cinco anos é de $73 \%$ nos países desenvolvidos, enquanto que nos países em desenvolvimento é de $56 \%$. A média mundial estimada é de 69\% (INCA, 2009).

O prognóstico dos pacientes com melanoma depende do estádio do tumor à época do diagnóstico e é normalmente baseado nos parâmetros histopatológicos e na avaliação clínico-radiológica de possíveis metástases. Dentre os parâmetros prognósticos, a espessura tumoral é o mais sensível em prever o risco de metástases. Entretanto, ainda é difícil de determinar o 
prognóstico individual para os pacientes, uma vez que melanomas de espessura mais fina também podem resultar em metástases letais (Dadras et al., 2005).

Os melanomas quando são reconhecidos precocemente, podem resultar em cura clínica pela remoção cirúrgica, sendo que $80 \%$ dos casos são tratados dessa maneira. No entanto, na fase metastática não há um tratamento efetivo, pois os indivíduos são frequentemente resistentes à terapia (Rass e Hassel, 2009).

\subsection{Características do Melanoma Cutâneo}

O melanoma pode surgir a partir da pele normal ou de uma lesão pigmentada preexistente. A manifestação da doença na pele normal se dá a partir do aparecimento de uma pinta escura de bordas irregulares e nos casos de uma lesão pigmentada preexistente, ocorre aumento no tamanho com alteração na coloração e forma da lesão que passa a apresentar bordas irregulares. $O$ parâmetro $A B C D$ é utilizado para o reconhecimento do melanoma cutâneo em lesões melanocíticas (Assimetria, Bordas irregulares, Coloração e Diâmetro), além de crescimento rápido, descamação, ulceração, sangramento, prurido, dor e desenvolvimento de áreas papulosas ou nodulares sobre máculas pigmentadas (Lee e Claridge, 2005, She et al., 2007, Messadi et al., 2009). 
Parâmetros histopatológicos como local de acometimento do tumor, níveis de invasão de Clark, espessura de Breslow e fase de crescimento (radial ou vertical) são considerados na avaliação do paciente (MacKie, 2000, Rass e Hassel, 2009). O procedimento médico após o reconhecimento da neoplasia é a ressecção cirúrgica da lesão suspeita e a confirmação histológica e, em seguida, procede-se à complementação do estadiamento para se definir a proposta terapêutica.

O estadiamento do melanoma pode ser dado de acordo com o nível de invasão tumoral na classificação proposta por Clark ou pelo índice de Breslow, que determina a espessura do tumor sendo esta a classificação mais utilizada atualmente (Machado et al., 2004). A classificação de Clark, definida pelo Dr. Walace Clark em 1967, é utilizada para definir o nível de invasão de melanomas finos: nível I (crescimento intra-epidérmico), nível II (invasão da derme papilar), nível III (atinge o limite entre derme papilar e reticular), nível IV (invasão da derme reticular) e nível $\mathrm{V}$ (invasão do tecido celular subcutâneo (Balch et al., 2004). Já o índice de Breslow, proposto pelo Dr. Alexander Breslow em 1970, determina a espessura tumoral (dimensão vertical a partir do ponto mais profundo de invasão ao topo da camada granulosa ou à célula mais superficial em caso de ulceração) e é subdividido em quatro níveis: I = $\leq 1,0 \mathrm{~mm}$; II = 1,01- 2,0 mm; III = 2,1 - 4,0 mm; IV $=>$ 4,0 mm (Balch et al., 2004).

Em tumores com espessura maior que $1 \mathrm{~mm}$ é recomendado ao paciente a biópsia do linfonodo sentinela, que é o primeiro sítio de drenagem na área entre o tumor primário e a cadeia linfática. Este conceito 
baseia-se na hipótese de que a drenagem linfática ocorre de maneira ordenada a partir do tumor primário para um primeiro linfonodo, o sentinela, e então para o restante da rede linfática (Mariani et al., 2002).

\subsection{Fatores de Risco do Melanoma}

Melanoma acomete indivíduos jovens e de meia-idade, ao contrário da maioria dos outros tumores sólidos, que afetam principalmente adultos mais velhos. A idade média do diagnóstico é de 57 anos, e a média de idade na morte é de 67 anos (Markovic et al., 2007). A distribuição dos locais de ocorrência do tumor é sexo-dependente: as áreas mais comuns são o dorso para os homens e os braços e pernas para as mulheres (Rigel, 2008). Populações brancas apresentam um risco aproximadamente 10 vezes maior de desenvolver melanomas do que as negras, asiáticas ou hispânicas. Isso é provavelmente devido à maior sensibilidade da pele branca à exposição solar (Kauffmann et al., 2008).

Diversos fatores de risco foram identificados como associados ao desenvolvimento do melanoma, entre eles a história familial de melanoma, sensibilidade da pele ao sol, exposição à radiação ultravioleta, bronzeamento artificial, o número de nevos, a presença de nevos displásicos ou atípicos, presença de sardas e cores claras de cabelo, olhos e pele (Landi et al., 2002, Markovic et al., 2007). 


\subsection{Mecanismos de Dano ao DNA por Exposição aos Raios UV}

Os cânceres de pele resultam de eventos bioquímicos simultâneos e sucessivos, iniciados pela radiação ultravioleta (UV) de diferentes comprimentos de onda (UVA e UVB). Essas radiações produzem danos no DNA que na ausência de reparo, podem levar a mutações em protooncogenes e genes supressores de tumor, originando assim o câncer (Sarasin, 1999). Dados epidemiológicos e experimentais sugerem que a radiação ultravioleta (UV) é um importante carcinógeno ambiental envolvido na iniciação e na progressão do câncer de pele (Bendesky et al., 2006, Rigel, 2008). Quando a pele é exposta à luz solar, uma parte da radiação é refletida enquanto a outra parte é absorvida, sendo que os raios UVA e UVB agem diferentemente nas células deste tecido (Marrot e Meunier, 2008).

O comprimento de onda curto do UVB (290-320nm) pode causar danos em proteínas ou em membranas celulares, e gerar estresse oxidativo, no entanto, ele também pode agir diretamente no DNA das células epiteliais e induzir lesões resultantes da absorção direta de fótons. Essas lesões têm sido relatadas como importantes fatores na morte celular, indução de mutações e câncer em decorrência da exposição aos raios UV. Os danos gerados no DNA apresentam-se na forma de dímeros de pirimidina de ciclobutano (ligação entre os carbonos 5 e 6 das bases pirimídicas adjacentes) e fotoprodutos de pirimidina (ligação entre os carbonos 6 e 4) conforme apresentado na Figura1. A dimerização de pirimidinas, induzidas pela radiação UV, resulta na distorção da estrutura do DNA que pode 
bloquear a replicação e transcrição da molécula (Bendesky et al., 2006, Marrot e Meunier, 2008) ou dar início ao processo de fotocarcinogênese (Heo et al., 2001, Wang et al., 2005).

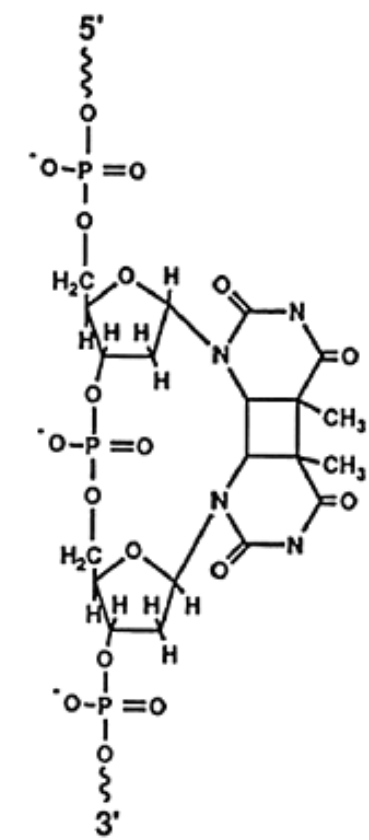

dímero de pirimidina de ciclobutano

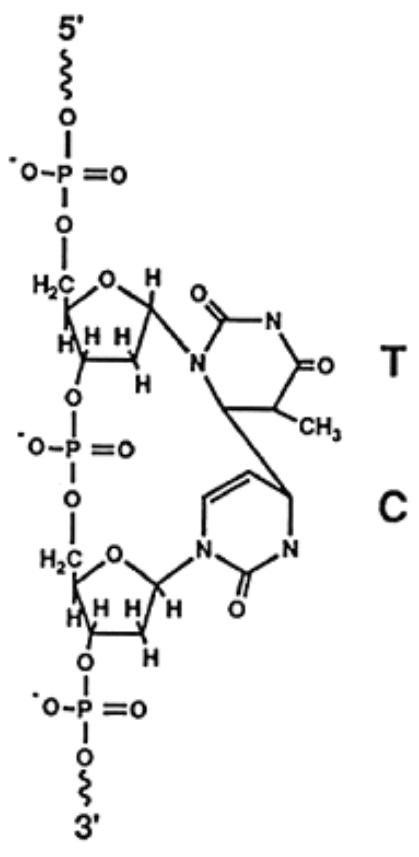

6-4 dímero de pirimidina

Figura 1: Representação esquemática de estruturas químicas de dímeros de pirimidina que se formam na molécula de DNA após exposição aos raios UV (Adaptado de Marrot e Meunir, 2008)

Os raios UVA (320-400nm) quando incidentes nas células epiteliais podem causar quebras de fitas simples do DNA, crosslink de DNA-proteína, além de induzirem a formação de radicais livres, as chamadas espécies reativas de oxigênio (ROS), que causam danos oxidativos ao DNA. As células respondem a essas lesões causadas pela irradiação UV por meio da ativação de diferentes mecanismos de reparo do DNA (Winsey et al., 2000, Marrot e Meunier, 2008). 
A evidência de que apenas uma fração dos indivíduos expostos à luz solar desenvolvem o melanoma sugere que a variabilidade genética tenha um papel importante na etiologia do melanoma (Wei et al., 2003). As pessoas diferem quanto à resposta aos mutágenos em decorrência de fatores individuais, que incluem não só os hábitos diários (fumo, medicamentos, drogas ilícitas, álcool ou mesmo a ingestão de antioxidantes, entre outros), provavelmente em decorrência do perfil genético que pode favorecer ou não a eliminação de metabólitos potencialmente mutagênicos e/ou carcinogênicos (Autrup, 2000, Millikan et al., 2006). A capacidade individual de reparo de danos gerados no DNA também pode ser modulada por variáveis genéticas como os polimorfismos em genes que codificam proteínas envolvidas no processo de reparo (Bendesky et al., 2006, GarciaSagredo, 2008).

\subsubsection{Mecanismos de Reparo do DNA à Exposição aos UV}

Sistemas de reparo do DNA atuam na manutenção da integridade do genoma e possuem um papel fundamental no reconhecimento de mutações que podem levar ao processo carcinogênico (Mohrenweiser e Jones, 1998, Sarasin e Kauffmann, 2008). Evidências sugerem que o processo de reparo quando não eficiente está associado com a maior suscetibilidade a outras neoplasias (Yu et al., 2004). A ausência ou reparo incorreto do DNA pode iniciar a carcinogênese pela ativação de oncogenes, inativação de genes supressores de tumor, ou pela perda de 
heterozigose (Winsey et al., 2000). A perda de um dos alelos em um locus específico pode modificar a expressão de genes que não se manifestam em heterozigose. Essa perda pode ocorrer devido à deleção de um cromossomo ou de parte dele, resultando ao final em um fenótipo homozigoto. Quando esta perda ocorre em um gene supressor tumoral, onde somente um dos alelos é selvagem e condiciona a característica, tal deleção pode favorecer a expressão do alelo mutante e resultar em uma transformação celular neoplásica.

Os mecanismos de reparo do DNA estão intimamente interligados com a regulação do ciclo celular, transcrição e replicação, processos esses que usam em parte, fatores comuns. Quando o tipo e a quantidade de danos superam a capacidade de reparo das células, esses mecanismos celulares essenciais podem ser seriamente afetados. Caso essas lesões não sejam removidas, podem levar as células à morte, ou resultarem na incorporação de mutações no genoma, que podem ser transmitidas para as gerações futuras (Berra et al., 2006). A capacidade individual de reparar danos no DNA pode refletir a suscetibilidade de um indivíduo em desenvolver câncer ou mesmo outras doenças (Schmezer et al., 2001, Andersson et al., 2007). Um exemplo é o Xeroderma Pigmentoso (XP), uma rara doença autossômica recessiva, associada a um risco mil vezes maior de desenvolver câncer de pele. Os portadores desta síndrome apresentam acúmulo de mutações no DNA, resultantes da exposição à radiação UV e decorrente da falta de um mecanismo eficiente de reparo do DNA (Tomescu et al., 2001, Kauffmann et al., 2008). 
Existem diferentes tipos de lesões que podem ocorrer no DNA como oxidação, alquilação, hidrólise e mau pareamento de bases, crosslinks, quebras de fita - simples e dupla, além de adutos de DNA, entre outros. Para cada um desses processos ocorre um reparo específico no DNA por meio de uma via de sinalização comum e como resultado, a alteração ou mesmo interrupção do ciclo celular (Rouse e Jackson, 2002, Houtgraaf et al., 2006). Basicamente, as vias de reparo do DNA podem ser classificadas em: reversão da lesão, reparo por excisão, reparo recombinacional e tolerância a lesões.

Três diferentes mecanismos podem ocorrer no reparo por excisão: reparo por excisão de base (BER), reparo por excisão de nucleotídeo (NER) e mismatch repair (MMR) (Leibeling et al., 2006, Sarasin e Kauffmann, 2008). O principal sistema de reparo de danos induzidos pela radiação UV é o reparo por excisão de nucleotídeo (Millikan et al., 2006, Kauffmann et al., 2008). O NER é a via de reparo que elimina a variedade mais ampla de lesões no genoma humano: é responsável pela remoção de dímeros de pirimidina causados pela radiação UV, adutos volumosos, crosslinks e danos oxidativos (Houtgraaf et al., 2006, Maddodi e Setaluri, 2008). Tal mecanismo de reparo consiste num processo de múltiplas etapas, envolvendo pelo menos 25 proteínas diferentes. Primeiramente a lesão no DNA é reconhecida e demarcada, em seguida ocorre incisão da fita em ambos os lados da lesão. Posteriormente, ocorre a excisão do segmento contendo a lesão e o espaço é preenchido com um novo segmento de DNA que é sintetizado a partir da fita não danificada, que serve como molde e finalmente, ocorre a união da molécula de DNA reparada (Blankenburg et al., 2005, Leibeling et al., 2006). 
Estudos epidemiológicos vêm sendo realizados com a finalidade de avaliar a contribuição de polimorfismos de genes de reparo do DNA no risco de diferentes tumores como de mama, tireóide, cabeça e pescoço, pele, pulmão, entre outros. (Collins e Harrington, 2002, Blankenburg et al., 2005, Wei et al., 2005).

\subsection{Tratamento do Melanoma}

Os melanomas quando são reconhecidos precocemente, isto é, numa fase de crescimento radial, e a doença ainda está localizada e restrita à pele, uma remoção cirúrgica apropriada pode resultar em cura clínica, sendo que $80 \%$ dos casos são tratados dessa maneira. No entanto, uma população celular com capacidade de desenvolver crescimento vertical possui um impacto negativo na sobrevida do paciente, com uma média de sobrevida entre seis meses e cinco anos (Kauffmann et al., 2008). Melanomas na fase de crescimento vertical possuem capacidade metastática, e uma vez que o processo se inicia, o tumor pode ser resistente à terapia (Gray-Schopfer et al. 2007, Rass e Hassel, 2009).

Pacientes com neoplasias malignas disseminadas são frequentemente tratados com uma combinação de drogas citostáticas que são, em sua maioria, genotóxicas (Elsendoorn et al., 2001, Rass e Hassel, 2009). As drogas citostáticas entram na célula por difusão íon-dependente ou transporte ativo mediado por proteínas carreadoras. Dentro da célula, agentes alquilantes reagem com sítios nucleofílicos de macromoléculas e 
formam adutos de proteína, RNA ou DNA. A reação com DNA gera adutos monofuncionais assim como crosslinks intra e inter-fitas da molécula. A formação de adutos resulta na inibição da replicação de DNA, transcrição de RNA, pausa na fase $\mathrm{G} 2$, e subsequente indução da morte celular programada (Röckmann e Schadendorf, 2003).

A maioria das drogas antineoplásicas é solúvel em fluidos corporais, podendo dessa maneira, ser distribuída sistemicamente. Apesar de os esforços terapêuticos serem direcionados aos tecidos cancerígenos, o DNA de células não cancerígenas também está sujeito aos danos decorrentes da quimioterapia (Kopjar et al., 2002). Assim, não somente as células tumorais sofrerão danos celulares e lesões no DNA, mas também tecidos normais podem ser severamente danificados durante a quimioterapia (Elsendoorn et al., 2001). Mais de 50 drogas citotóxicas estão disponíveis comercialmente para tratamento de pacientes com câncer. Estudos clínicos e laboratoriais têm provado que muitas destas são mutagênicas, carcinogênicas, ou teratogênicas em humanos e animais. Os pacientes que receberam dosagens terapêuticas dessas drogas apresentaram diversos efeitos colaterais agudos e crônicos, como náusea, vômito, nefrotoxicidade, insuficiência renal, mucosite, anemia, e inclusive cânceres secundários (Sánchez-Suárez et al., 2008).

O prognóstico do melanoma pode ser considerado bom, se detectado nos estágios iniciais. Nos últimos anos, houve uma grande melhora na sobrevida dos pacientes, principalmente devido à detecção precoce do câncer (Rass e Hassel, 2009). Nos países desenvolvidos, a sobrevida média estimada em cinco anos é de $73 \%$, enquanto que, para os países em desenvolvimento, a sobrevida média é de $56 \%$ e a média mundial estimada é de $69 \%$ (INCA, 2009). O baixo prognóstico de cinco anos é resultante 
principalmente da resistência aos quimioterápicos utilizados no tratamento do melanoma (Grossman e Altieri, 2001).

Uma causa fundamental da eficácia limitada das drogas citotóxicas no tratamento do melanoma em estádio avançado se deve aos mecanismos de quimiorresistência (Rass e Hassel, 2009). Poucos fármacos mostram eficácia contra o melanoma, exceto a dacarbazina, as nitrosureias e a cisplatina. Essas drogas são administradas isoladamente ou em combinações (NCCN, 2006). A administração de quimioterápicos baseados na platina tem sido utilizada amplamente em tratamentos de uma variedade de tumores durante as últimas três décadas.

A cisplatina foi o primeiro agente platínico a ser usado como quimioterápico no começo dos anos 70 , possui um potencial inibitório na divisão celular e eficiência no tratamento de diversos tipos de câncer como de ovário, bexiga, pulmão, cabeça e pescoço, sendo principalmente efetivo no câncer de testículo (Wang e Lippard, 2005, Almeida et al., 2006).

A cisplatina (cis-diaminodicloroplatina (II) ou cis-DDP), conforme apresentado na Figura 2, é administrada intravenosamente e tem como alvo principal a molécula de DNA (Hovhannisyan et al., 2004).

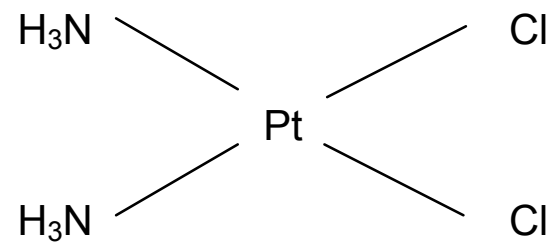

Figura 2: Representação da estrutura química da cisplatina (cisdiaminodicloroplatina (II) ou cis-DDP) 
Acredita-se que o efeito terapêutico é consequência da ligação da cisplatina com o DNA que ao formar adutos que não são removidos, podem bloquear a replicação e transcrição do DNA, levando à morte celular. A cisplatina forma uma variedade de adutos como o crosslink inter-fita e o aduto monofuncional, no entanto, o mais prevalente (>90\%) é o crosslink 1,2 intra-fita, em que a cisplatina liga-se preferencialmente com o N7 de purinas e os principais adutos são cis- $P t\left(\mathrm{NH}_{3}\right)_{2} \mathrm{~d}(\mathrm{pGpG})$ e cis-Pt( $\left(\mathrm{NH}_{3}\right)_{2} \mathrm{~d}(\mathrm{pApG})$, conforme apresentados na Figura 3 (Zamble e Lippard, 1995, Wozniak e Blasiak, 2002, Martin et al., 2008). Os danos induzidos pela cisplatina não são fáceis de reparo devido a eficiente ligação com o DNA, o que favorece sua eficiência como droga antitumoral (Kosmider et al., 2005),

(a)

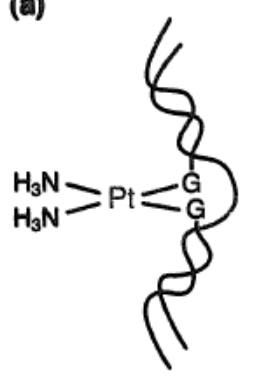

(b)

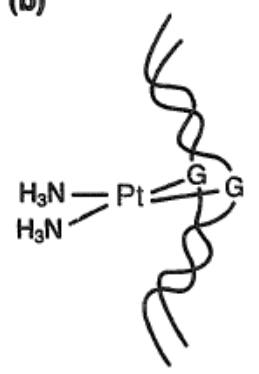

(c)

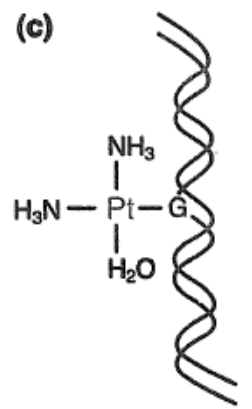

Figura 3: Representação esquemática dos adutos cisplatina-DNA incluindo crosslink intra-fita (a), crosslink inter-fita (b) e aduto monofuncional (c) (Adaptado de Zamble e Lippard, 1995)

Um perfil semelhante de adutos é observado em DNA isolados de linfócitos de pacientes com câncer após tratamento com cisplatina, confirmando in vivo a ação da droga in vitro. Entretanto, os níveis de adutos 
são similares em tumores e em outros tecidos dos pacientes após a quimioterapia, indicando que a cisplatina não se localiza especificamente no tecido tumoral (Trimmer e Essigmann, 1999).

A cisplatina parece exercer seu efeito citotóxico pela inibição da replicação do DNA com efeito seletivo em células em rápida divisão, como as células tumorais. No entanto, a atividade antitumoral da cisplatina, não está baseada apenas na habilidade de inibir a replicação do DNA, sendo que outros mecanismos, como a inibição da transcrição, também estão envolvidos (Siddik, 2003). De fato, a síntese de RNA e a replicação de DNA são eventos mais críticos para uma célula tumoral em rápida divisão, em relação a uma célula estacionária. Quando ocorre o reparo celular em resposta ao dano causado pela cisplatina, as células aumentam as chances de sobrevivência. O reparo por excisão de nucleotídeos é o principal processo pelo qual os adutos de DNA formados pela cisplatina são removidos (Jordan e Carmo-Fonseca, 2000).

O NER é um complexo multiprotéico que reconhece o aduto do crosslink 1,2 intra-fita e remove a parte do DNA lesado, que inclui de 27 a 29 pares de bases. A nova fita sintetizada pela DNA polimerase é então inserida, reparando o dano (Figura 4). Estudos relatam que pelo menos 16 genes são essenciais para o reconhecimento do dano no DNA e excisão do aduto formado pela cisplatina (Cepeda et al., 2007). Por outro lado, NER ineficiente talvez contribua para a atividade antitumoral da droga (Trimmer e Essigmann, 1999, Jordan e Carmo-Fonseca, 2000). 

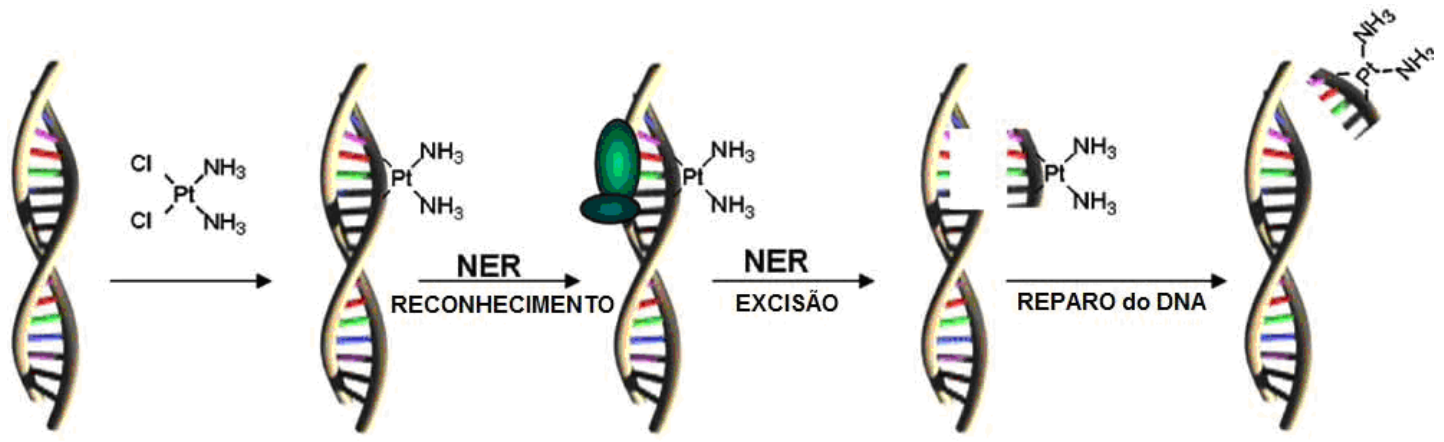

Figura 4: Esquema das etapas envolvidas no reparo do crosslink 1,2 intra-fita pelo sistema de reparo por excisão de nucleotídeos (NER) (Adaptado de Cepeda et al., 2007)

A resistência às drogas muitas vezes impede o funcionamento da quimioterapia baseada na cisplatina para curar pacientes com câncer e o aumento da dose do quimioterápico pode ser tóxico para o paciente. Há dois tipos de resistências à cisplatina: intrínseca e adquirida. A resistência intrínseca ocorre em pacientes em que os tumores são inerentemente resistentes e não respondem à cisplatina no primeiro momento do tratamento. Já a resistência adquirida pode surgir em populações de células tumorais após uma resposta inicial à droga (Martin et al., 2008, Rass e Hassel, 2009).

O desenvolvimento de resistência é um processo multifatorial, podendo estar relacionado ao transporte de fármacos, com um aumento do efluxo da droga após esta já ter adentrado na célula tumoral mediado por proteínas relacionadas ao fenótipo de resistência a múltiplas drogas (MDR); a alterações em moléculas alvo que vão se acoplar com as drogas quimioterápicas para que estas exerçam seus efeitos antitumorais, diminuindo assim a sua afinidade pela droga quimioterápica; à detoxificação 
e reparo de DNA mais intenso, levando à inativação de eventuais danos pelas medicações antineoplásicas e a alterações no mecanismo de morte celular programada ou à apoptose do qual dependem algumas medicações quimioterápicas para sua ação antitumoral (Perez, 1998, Jordan e CarmoFonseca, 2000, Grossman e Altieri, 2001). Sendo assim, um tumor pode se tornar resistente por um ou mais mecanismos (Chu, 1994, Trimmer e Essigmann, 1999, Martin et al., 2008).

A busca por um indicador que seja capaz de prever as respostas individuais à quimioterapia antes do tratamento tem sido alvo de pesquisa de diversos autores (Nadin et al., 2006, Kauffmann et al., 2008, Sarasin e Kauffmann, 2008). Apesar de o melanoma ser curável em fase inicial, não existe ainda tratamento efetivo para o melanoma metastático, em parte em decorrência do fato deste tumor ser um dos mais resistentes à terapia. Identificar os alvos moleculares para o diagnóstico e tratamento de pacientes é de extrema importância e tem sido o foco de pesquisas recentes de melanoma (Marquette et al., 2007, Hocker et al., 2008, Rass e Hassel, 2009).

\subsection{Testes Citogenéticos}

Diferentes ensaios citogenéticos têm sido utilizados no monitoramento de populações expostas a agentes mutagênicos, incluindo os pacientes que se submetem a tratamentos com drogas antineoplásicas. Entre eles estão diferentes técnicas que identificam danos em células individualizadas, como 
o teste do Cometa, detecção de aberrações cromossômicas e troca de cromátides-irmãs em linfócitos de sangue periférico e o teste do micronúcleo em linfócitos de sangue periférico ou células de escamação da mucosa de revestimento. Alguns destes testes são utilizados em populações ocupacionalmente expostas a substâncias potencialmente mutagênicas para avaliar de forma precoce o risco de câncer (Takahashi, 2003, GarciaSagredo, 2008). Esses testes são considerados métodos sensíveis e alguns deles de relativo baixo custo, sendo que em humanos os testes em linfócitos de sangue periférico são os mais utilizados, podendo ser realizados tanto in vivo como in vitro. A vantagem dos linfócitos humanos é que por circularem em todos os órgãos servem de sentinelas da exposição genotóxica, independentemente da via de administração (oral, inalatória, dérmica, intravenosa, etc), além de revelarem os danos de exposição recente em decorrência da curta longevidade dessas células (Garcia-Sagredo, 2008).

\subsubsection{Teste do Micronúcleo (MN)}

O teste do micronúcleo (MN) é considerado rápido e econômico e vem sendo aplicado como teste de screening de populações humanas expostas a agentes potencialmente mutagênicos e/ou carcinogêncios (Heddle et al., 1991, Fenech, 2006). Os MN são identificados na intérfase de células em divisão e se apresentam na forma de pequenos corpúsculos citoplasmáticos. Correspondem a fragmentos acêntricos resultantes de deleções cromossômicas ou cromossomos inteiros que se atrasam durante a anáfase da divisão celular. Portanto, MN são visualizados em células que 
passaram por um ciclo de divisão (Fenech, 1997, Garcia-Sagredo, 2008). A Figura 5 apresenta de forma esquemática a formação de MN em células binucleadas após manutenção das células em cultura e adição de citocalasina B, que impede a citocinese.

$\mathrm{O}$ aumento na frequência de $\mathrm{MN}$ em linfócitos binucleados de sangue periférico, da mesma forma que as aberrações cromossômicas estruturais, parecem ser biomarcadores preditivos de câncer em populações humanas (larmarcovai et al., 2008). O reparo de DNA deficiente também pode estar associado ao aumento da frequência de MN (Bonassi et al., 2007).

A

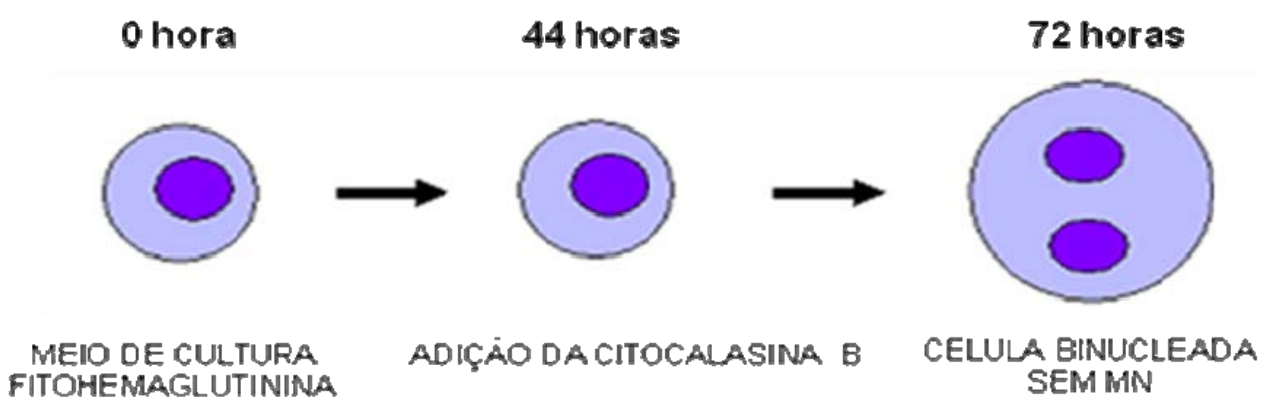

B

o hora

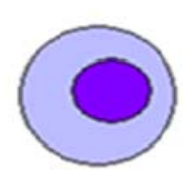

MEIO DE CULTURA FITOHEMAGLUTININA
44 horas

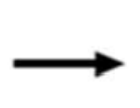

ADIÇÃOO DA CITOCALASINA B

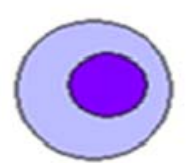

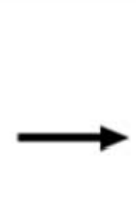

\section{2 horas}

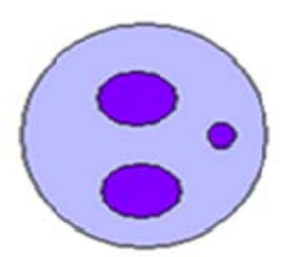

CÉLULA BINUCLEADA COM MN

Figura 5: Linfócitos de sangue periférico após serem estimulados à divisão, in vitro, são impedidos de fazer a divisão citoplasmática na presença de citocalasina B. Células binucleadas sem MN (A) ou com MN (B) são consideradas na análise citogenética. 
Murgia e colaboradores (2008) realizaram um estudo para avaliar o valor preditivo da frequência de $\mathrm{MN}$ em linfócitos no risco de desenvolver neoplasias, comparando pacientes com câncer e indivíduos saudáveis. Pacientes com câncer apresentavam maior quantidade de $\mathrm{MN}$ em relação aos indivíduos controles. O mesmo também foi observado por Karaman e coloboradores (2008), num estudo com pacientes com adenocarcinoma colorretal que foram comparados a um grupo controle e estudos também demonstraram o aumento de formação de $\mathrm{MN}$ após o tratamento de radioterapia (Gamulin et al., 2008). Os estudos sugerem que a avaliação da frequência de $\mathrm{MN}$ em linfócitos de sangue periférico é um bom preditivo no risco de suscetibilidade ao câncer.

\subsubsection{Teste do Cometa}

O teste do Cometa também conhecido como SCG ("single cell gel assay") ou MGE ("microgel electrophoresis") foi introduzido primeiramente por Östling e Johanson em 1984 como uma técnica microeletroforética para visualização direta de danos no DNA em células individualizadas (Fairbain et al., 1995, Collins, 2004). É uma técnica rápida, qualitativa e quantitativa útil para mensurar danos de DNA em células eucarióticas, sendo capaz de detectar quebras de fita simples e dupla, sítio de reparo incompleto, sítios álcali-labeis, e crosslinks DNA-proteínas e crosslinks DNA-DNA (Olive e Durand, 2005, Burlinson et al., 2007). 
Neste ensaio que inclui eletroforese, o DNA que possui algum tipo de lesão na sua estrutura migrará para longe do núcleo com DNA íntegro, o que resulta à célula o aspecto de um Cometa. Para a interpretação dos resultados, o "cometa" é dividido em duas partes: cabeça e cauda. Assim, células sem ou com pouco dano no DNA não apresentam cauda, enquanto células com mais danos apresentam caudas maiores. Atualmente, o tamanho, intensidade da fluorescência, aspecto e outras características dos Cometas são mensurados visualmente por microscopia ou por programas específicos de análise de imagem (Gontijo e Tice, 2003, Liao et al., 2009).

As lesões no DNA, detectadas pelo teste do Cometa, podem ou não resultar em mutações em uma única célula e, consequentemente, em determinadas sub-populações celulares (Gontijo e Tice, 2003, McArt et al., 2009). O teste do Cometa tem sido frequentemente utilizado como biomarcador de exposição na avaliação de populações de risco e nos estudos de reparo de DNA e apoptose (Kopjar et al., 2002, Moller, 2006). Também no teste do Cometa, grande parte dos estudos é realizada em linfócitos humanos, principalmente no biomonitoramento de populações expostas (Trzeciak et al., 2008).

Outra aplicação deste teste consiste na identificação da variação individual na capacidade de reparo do DNA (McArt et al., 2009, Liao et al., 2009). Com a finalidade de avaliar a resposta clínica à quimioterapia, pesquisadores verificaram o dano causado no DNA e seu respectivo reparo comparando linfócitos de sangue periférico de indivíduos saudáveis e de pacientes com câncer. A análise da capacidade de reparo de DNA pode ser 
um biomarcador importante para identificação de fatores de risco associados ao câncer (Faust et al., 2004, McKenna et al., 2008). Por outro lado, a resposta clínica à quimioterapia, também pode ser avaliada por meio do teste do Cometa comparando linfócitos de sangue periférico de indivíduos saudáveis e de pacientes com câncer em tratamento (Nadin et al., 2007).

O teste do Cometa é uma técnica que detecta danos recentes ainda passíveis de reparo, já o teste do MN detecta danos consolidados, por isso, o uso de ambas as técnicas citogenéticas, em uma mesma população permite sugerir características de exposição, importante em estudos de biomonitoramento (Maluf, 2004). 
2 OBJETIVOS 
O presente trabalho teve como objetivos:

- Avaliar os danos basais do DNA em linfócitos de sangue periférico de pacientes com melanoma e de indivíduos sem a doença, pelos testes citogenéticos do Cometa e do Micronúcleo.

- Avaliar, utilizando o teste do Cometa, a ação da cisplatina e a capacidade de reparo do DNA de pacientes com melanoma e controles, após tratamento dos linfócitos, in vitro, com o quimioterápico. 
3 MÉTODOS 


\subsection{Casuística}

Esse estudo foi realizado em pacientes do Hospital das Clínicas da Faculdade de Medicina da Universidade de São Paulo (HCFMUSP) e os testes citogenéticos no Laboratório de Imuno-Hematologia e Hematologia Forense (LIM 40) do Departamento de Medicina Legal, Ética Médica e Medicina Social e do Trabalho da Faculdade de Medicina da Universidade de São Paulo.

Para a presente investigação foram considerados 20 pacientes com melanoma e 20 controles, ambos selecionados no mesmo hospital. Os pacientes, de ambos os sexos, foram atendidos na Clínica Dermatológica do Hospital das Clínicas da Faculdade de Medicina da USP, com idades entre 35 e 60 anos e diagnóstico de melanoma cutâneo, confirmado por exame histopatológico e sem tratamento com quimioterápicos. Não foram elegíveis os indivíduos com Xeroderma pigmentoso ou com melanoma acral (planta e palma), em leito ungueal, área genital, ânus, borda anal, ouvido interno e mucosa oral.

O grupo controle foi selecionado entre os doadores voluntários do Banco de Sangue do Hospital das Clínicas, de acordo com o sexo e faixa etária dos pacientes com melanoma. Os controles não possuíam suspeita de melanoma ou de qualquer outro tipo de câncer. A seleção e coleta de 
material biológico dos pacientes e dos controles foram feitas simultaneamente e o material foi processado no mesmo dia.

Após esclarecimentos sobre o projeto, os indivíduos assinaram um termo de Consentimento Livre e Esclarecido, previamente aprovado na Comissão de Ética em Pesquisa do Hospital das Clínicas da Faculdade de Medicina USP (Cappesq Processo n 0862/07).

\subsection{Entrevistas}

Nas entrevistas realizadas com os pacientes e com os indivíduos controles foi utilizado um instrumento de avaliação adaptado. Este instrumento incluiu questões sobre cor da pele do indivíduo e de seus ascendentes, uso de medicamentos, exposição a radiações ionizantes, tabagismo, consumo de álcool, história familial de câncer, ocupação, atividades de lazer, local de férias, uso de equipamento de bronzeamento artificial, exposição a fontes artificiais de ultravioleta, uso de filtro solar, uso de bronzeador, história de queimadura solar, cor da pele, cor dos olhos, cor do cabelo, sensibilidade da pele ao sol, entre outras. O mesmo questionário foi aplicado ao grupo controle (Anexo 1).

A classificação da cor da pele dos indivíduos foi feita no momento da aplicação do questionário que incluiu também questões sobre a cor de pele dos pais, sendo então divididos em brancos e não brancos. Quanto aos hábitos de bebida e fumo, foram definidos como consumidores aqueles que relataram 
ingerir bebidas alcoólicas pelo menos uma vez por mês e ex-consumidores aqueles que não consumiam há mais de um ano; os ex-fumantes foram definidos como aqueles que não fumavam há mais de um ano.

\subsection{Testes Citogenéticos e Critérios de Análise}

Amostras de sangue periférico $(8 \mathrm{~mL})$ dos pacientes e controles foram coletadas, por punção venosa em sistema a vácuo, em tubos contendo heparina. Para a realização dos testes, os linfócitos foram separados por centrifugação (15 minutos a 3500rpm). O anel de leucócitos e pequena quantidade de plasma e soro foram transferidos para um tubo estéril e utilizados após serem homogeneizados.

Os testes do micronúcleo (MN) e do Cometa foram realizados para avaliar os danos basais do DNA. Para avaliar os danos do DNA causados pela cisplatina e a capacidade de reparo dos linfócitos, in vitro, foi utilizado somente o teste do Cometa.

\subsubsection{Teste do MN}

O teste do MN foi realizado em metade da população do estudo, ou seja, 10 pacientes e 10 controles. Culturas de linfócitos de sangue periférico foram realizadas segundo técnica modificada por Ellard e Parry (1993) para avaliar os danos basais do DNA. O volume de $185 \mu \mathrm{L}$ de homogeneizado de 
leucócitos foi distribuído em frascos contendo $5 \mathrm{~mL}$ de meio cada. O meio de cultura utilizado constituiu de 80\% de RPMI 1640 (Gibco), suplementado com $20 \%$ de soro bovino fetal inativado (Cultilab), o qual após esterilização em filtro (Seitz Milipore) foi suplementado com $50 \mu \mathrm{L}$ de fito-hemaglutinina-P (Difco).

Todas as culturas do experimento foram realizadas simultaneamente e em duplicata (A e B). As culturas foram mantidas em estufa a $37^{\circ} \mathrm{C}$, onde permaneceram por um total de 72 horas. Após 44 horas de incubação, foi adicionado a citocalasina B (Sigma), dissolvida em dimetilsulfóxido (DMSO Merck) na concentração de $6 \mu \mathrm{g} / \mathrm{mL}$ de meio.

Ao final das 72 horas, o conteúdo dos frascos foi transferido para tubos de centrífuga e submetido à centrifugação a 1500 rpm por 5 minutos. Após desprezar o sobrenadante, foram acrescentados $4 \mathrm{~mL}$ de solução de soro fisiológico e $4 \mathrm{~mL}$ de solução fixadora, constituída de metanol e ácido acético (ambos da Merck), na proporção de 3:1. Repetiu-se o processo de trocar o fixador por mais duas vezes, sempre desprezando o sobrenadante. O material foi ressuspendido em $1 \mathrm{~mL}$ de fixador e 2 a 3 gotas dessa suspensão foram pingadas em lâminas de vidro úmidas, previamente limpas e conservadas em água destilada a $4^{\circ} \mathrm{C}$. O restante da suspensão foi conservado no freezer.

Para a coloração, as lâminas foram secas em temperatura ambiente, e posteriormente coradas com solução de Giemsa (Merck) diluído em tampão fosfato $0,06 \mathrm{M}$, por 5 minutos. Após a coloração, a montagem das lâminas foi feita com lamínula e Erv-mount. 


\section{Critérios de Análise}

Foram analisados 1000 linfócitos binucleados por amostra de cada um dos pacientes e controles avaliados neste teste. Foram analisadas apenas células binucleadas, íntegras e isoladas, com membranas nucleares e citoplasmáticas preservadas. Foram considerados $\mathrm{MN}$ os corpúsculos citoplasmáticos com tamanho de no máximo $1 / 3$ dos núcleos principais, com forma arredondada, contorno regular e bem delimitado, com coloração e textura de cromatina em plano focal semelhante aos núcleos principais, segundo proposto por Fenech (2000). Para a análise dos MN foi utilizado microscópio NIKON, modelo Alphaphot 2 SYS, com iluminação simples e objetiva de 40X. As eventuais alterações foram confirmadas em aumento de 100X, com óleo de imersão (Figura 6).
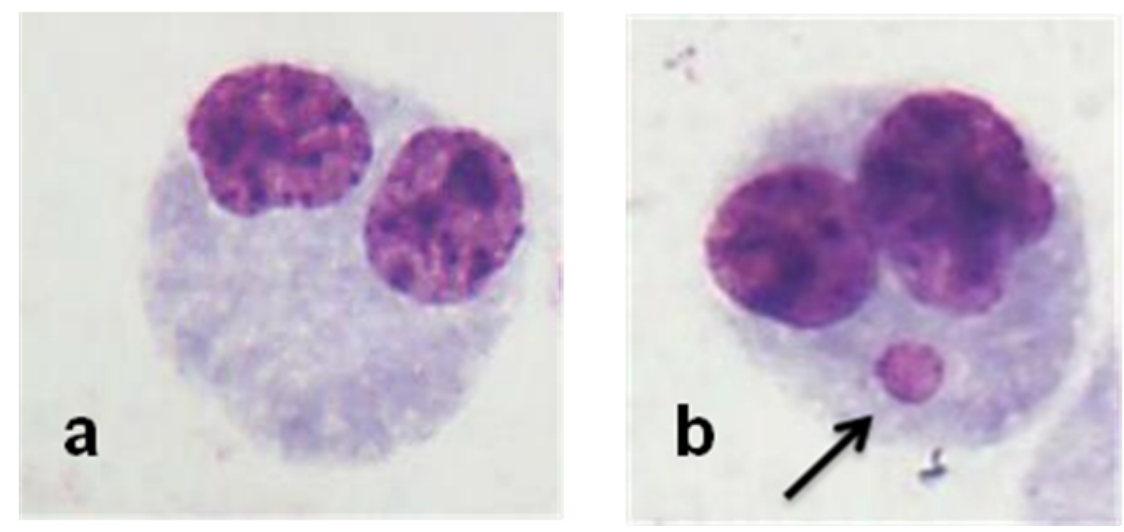

Figura 6: Representação de um linfócito de sangue periférico binucleado obtido após a adição de citocalasina B em cultura, sem (a) e com micronúcleo (b). Fotos referentes a culturas analisadas de pacientes com melanoma e controles 


\subsubsection{Teste do Cometa}

O teste do Cometa foi realizado em 20 pacientes com melanoma e 20 controles e permitiu a análise dos danos basais existentes, os danos de DNA causados pela cisplatina e a capacidade de reparo, in vitro, dos linfócitos.

As concentrações da cisplatina foram previamente determinadas pelo teste de viabilidade celular. Foram testadas as concentrações de 10, 30,

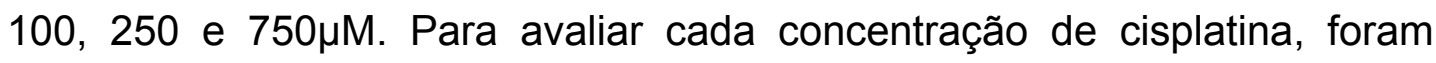
utilizados $10 \mu \mathrm{L}$ de sangue total em $10 \mathrm{~mL}$ de meio RPMI 1640 que ficaram em estufa a $37^{\circ} \mathrm{C}$ por uma hora. Após esse período, acrescentou-se $15 \mu \mathrm{L}$ da solução (suspensão celular + meio) à $15 \mu \mathrm{L}$ de Trypan Blue. Após homogeneizar a nova solução, pingou-se uma gota na Câmara de Newbauer onde as células viáveis foram contadas. Observou-se então se havia alguma célula corada em azul, o que indicaria células inviáveis, ou seja, mortas. Todas as concentrações avaliadas apresentaram viabilidade $>90 \%$, e então se optou pela avaliação das concentrações de cisplatina de 10, 100 e $250 \mu \mathrm{M}$ no teste do Cometa. Essas concentrações selecionadas são semelhantes às testadas na literatura (Blasiak et al., 2000).

O protocolo proposto por Blasiak e colaboradores (2000) foi utilizado e os tempos de avaliação pelo teste do Cometa foram: T1 (tempo 1) - após 1 hora de tratamento com o quimioterápico; T2 (tempo 2) - após 1 hora de reparo, T3 (tempo 3) - após 2 horas e meia de reparo e T4 (tempo 4) - após 5 horas de reparo. 
T1

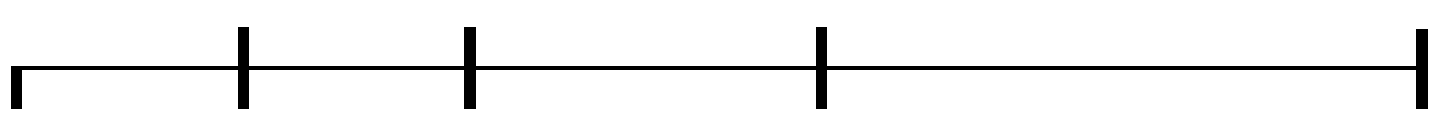

a

b

C

d

e

a) Separação dos linfócitos e tratamento dos controles (positivo, negativo e $\mathrm{H}_{2} \mathrm{O}_{2}$ - 5 min) e com a cisplatina por 1 hora;

b) colheita do $1^{\circ}$ cometa (T1) e lavagem dos linfócitos restantes com meio RPMI, estes permaneceram em estufa a $37^{\circ} \mathrm{C}$ até o momento de sua colheita;

c) colheita do $2^{\circ}$ cometa (T2) - 1 hora de reparo do DNA;

d) colheita do $3^{\circ}$ cometa (T3) - 2 horas e meia de reparo do DNA;

e) colheita do $4^{\circ}$ cometa (T4) -5 horas de reparo do DNA.

O teste do Cometa foi realizado segundo método de Singh et al. (1988), modificado. Um esquema dos processos envolvidos na execução do teste do Cometa encontra-se descrito na Figura 7. 


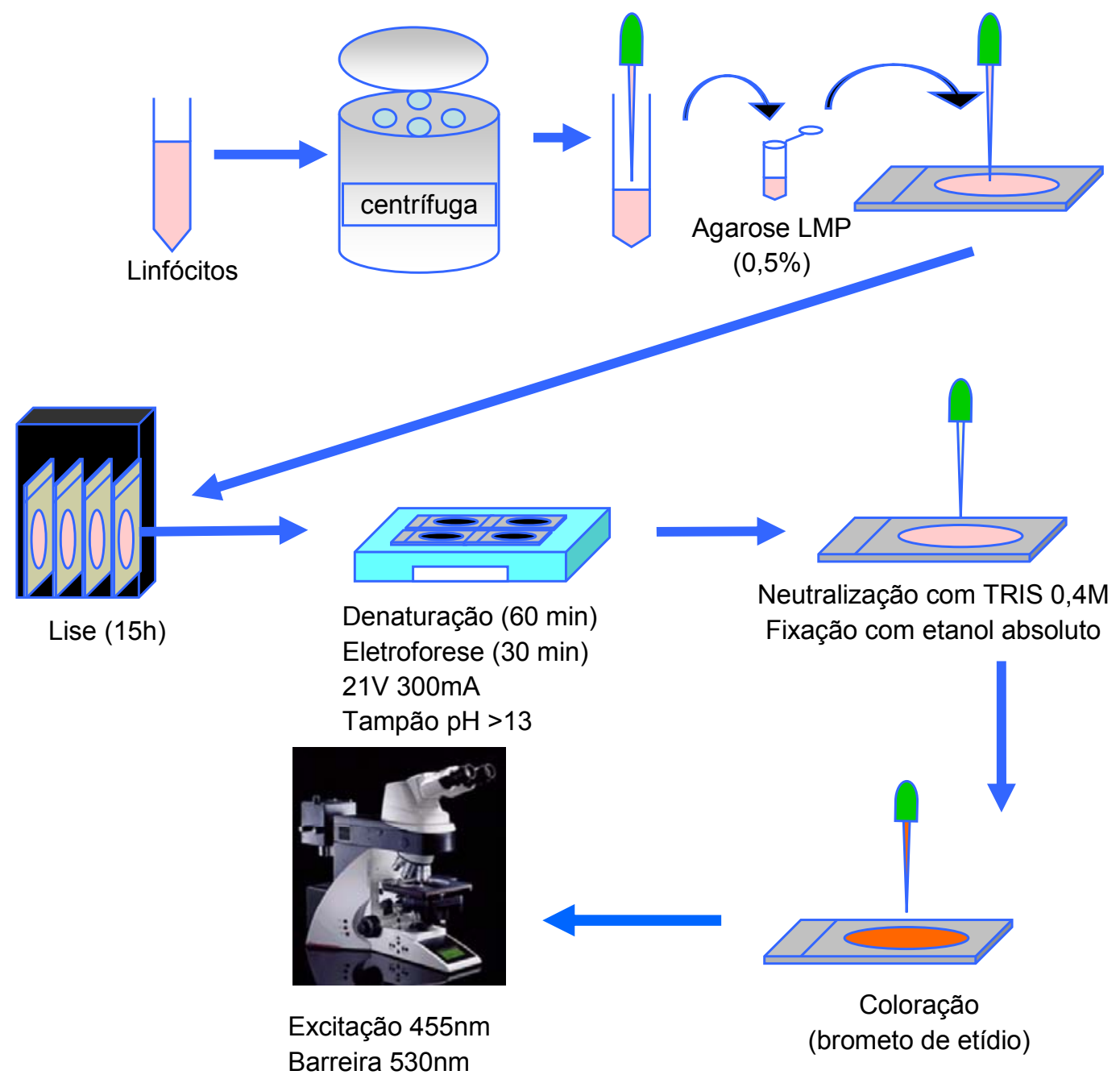

Figura 7: Representação esquemática dos procedimentos utilizados no teste do Cometa, realizado com linfócitos de sangue periférico de pacientes com melanoma e indivíduos controle 
Após a separação dos linfócitos, $10 \mu \mathrm{L}$ de linfócitos em meio $1 \mathrm{~mL}$ de meio de cultura RPMI 1640 suplementado com 20\% de soro bovino inativado foram incubados por uma hora em estufa $37^{\circ} \mathrm{C}$ com seus respectivos tratamentos:

- controle positivo: $25 \mu \mathrm{L}$ de $\mathrm{H}_{2} \mathrm{O}_{2} 30 \mathrm{~V}$;

- controle negativo: linfócitos incubados somente em meio de cultura (considerado na análise como o dano basal de cada indivíduo);

- controle $\mathrm{H}_{2} \mathrm{O}_{2}: 10 \mu \mathrm{M}$ (5minutos)

- cisplatina $10 \mu \mathrm{M}$;

- cisplatina $100 \mu \mathrm{M}$;

- cisplatina $250 \mu \mathrm{M}$.

Após esse período de uma hora de ação da droga, todos os microtubos contendo cisplatina foram acrescentados com $10 \mu \mathrm{M}$ de $\mathrm{H}_{2} \mathrm{O}_{2}$, que agiu durante 5 minutos para permitir a visualização de cauda do teste do Cometa. Os microtubos foram então centrifugados, retirou-se o sobrenadante e colocou-se novo meio RPMI 1640 naqueles em que o reparo do DNA seria avaliado. O primeiro teste do cometa foi realizado para avaliar a ação de uma hora da droga. Os outros microtubos (com as concentrações de 10,100 e $250 \mu \mathrm{M}$ de cisplatina) permaneceram em estufa, a $37^{\circ} \mathrm{C}$, aguardando o tempo de reparo de 1 hora, 2 horas e meia e 5 horas.

Em relação ao procedimento da técnica: após a centrifugação dos microtubos a 1500 rpm por 5 minutos, o sobrenadante foi desprezado e o sedimento, após ser homogeneizado, foi dividido em duas alíquotas de 
$7 \mu \mathrm{L}$ por microtubo. Foram adicionados a cada microtubo $100 \mu \mathrm{L}$ de agarose (Merck) com baixo ponto de fusão (LMP - low melting point) a 0,07\% dissolvida em tampão fosfato (PBS - Phosphate buffered saline) $\mathrm{pH} 7,4$ a $37^{\circ} \mathrm{C}$.

Paralelamente, foram preparadas lâminas com a primeira camada de agarose. As lâminas de vidro foram imersas em agarose (Merck) de ponto de fusão normal a $1,5 \%$ dissolvida em PBS $(\mathrm{pH} 7,4)$ a $45^{\circ} \mathrm{C}$. Depois de prontas, as lâminas secaram a temperatura ambiente, por 30 minutos, antes da adição da segunda camada de agarose LMP $(0,5 \%)$ com a suspensão de leucócitos. O material foi coberto com lamínula e mantido a $4^{\circ} \mathrm{C}$, por 10 minutos, para polimerização do gel.

Em seguida, as lamínulas foram retiradas e as lâminas foram colocadas em cubetas de vidro com solução de lise de membrana $(2,5 \mathrm{M}$ $\mathrm{NaCl}, 100 \mathrm{mM}$ EDTA, 10mM TRIS, 10\% DMSO, 1\% Sarcosinato de $\mathrm{Na}, 1 \%$ Triton-X) $\mathrm{pH} 10$, por 15 horas, a $4^{\circ} \mathrm{C}$, no escuro. A partir dessa etapa até o final da corrida de eletroforese, todo o procedimento ocorreu a $4^{\circ} \mathrm{C}$ e no escuro. Decorrido o tempo de lise, as lâminas foram colocadas em cuba de eletroforese horizontal com tampão de eletroforese (1mM EDTA, 300mM $\mathrm{NaOH}) \mathrm{pH}>13$, onde permaneceram por 60 minutos para o desenrolamento do DNA e, em seguida, foram submetidas a uma corrente de eletroforese de 21 volts e $300 \mathrm{~mA}$, por 30 minutos.

Após a corrida de eletroforese foi feita a neutralização das lâminas em 3 banhos, de 5 minutos cada, em solução de TRIS 0,4M (pH 7,5) e a fixação do material em etanol absoluto por 10 minutos, ambas em temperatura ambiente. O material foi armazenado em caixas para lâminas até o momento 
da análise. Somente no momento da análise, as lâminas foram coradas com 40 $\mu \mathrm{L} /$ lâmina de solução de brometo de etídio (Merck), na concentração de $20 \mu \mathrm{g} / \mathrm{mL}$. A Figura 8 apresenta um esquema dos tratamentos por indivíduo, antes da realização do teste do Cometa.

\section{1 hora de tratamento}

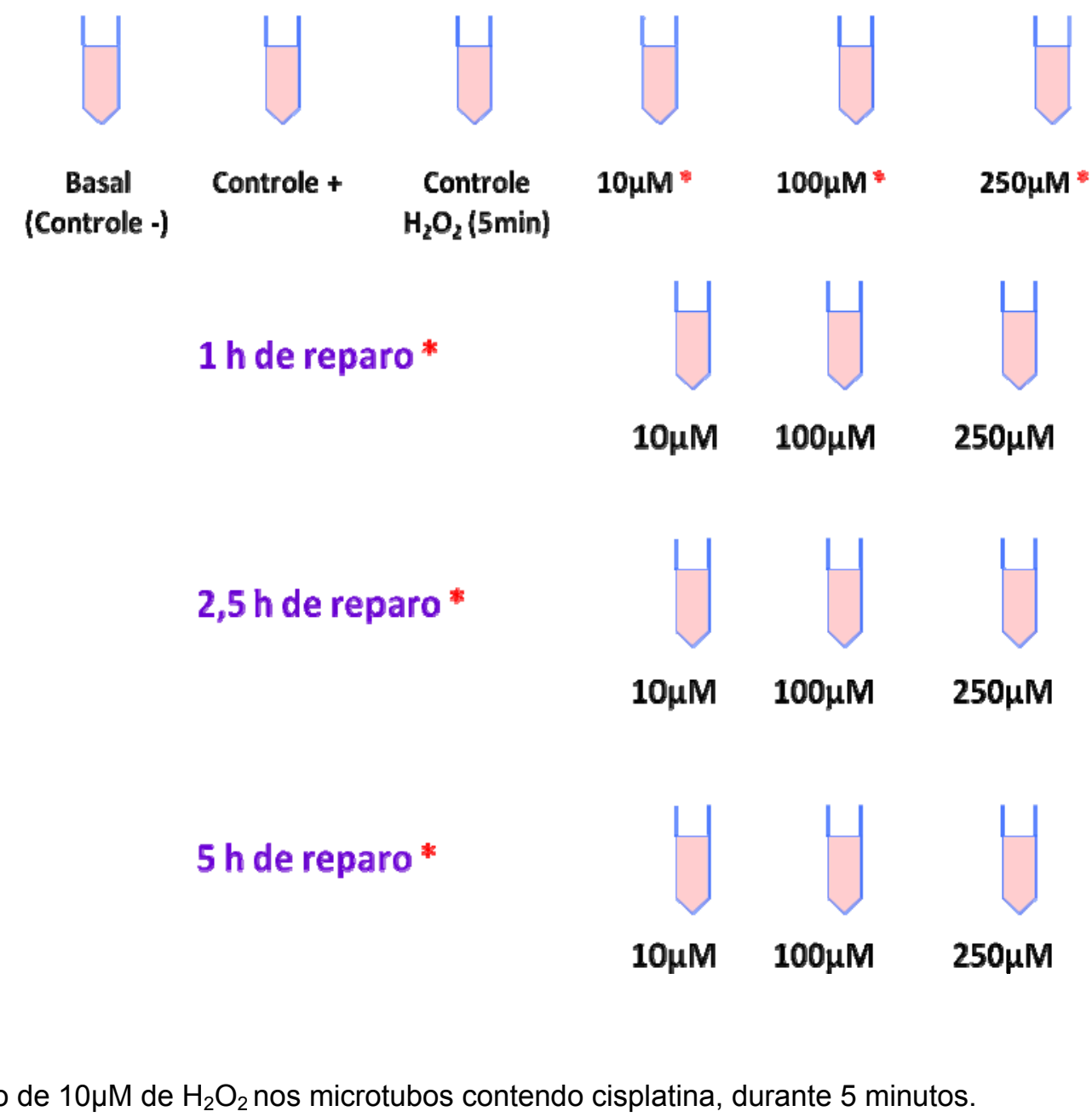

* adição de $10 \mu \mathrm{M}$ de $\mathrm{H}_{2} \mathrm{O}_{2}$ nos microtubos contendo cisplatina, durante 5 minutos.

Figura 8: Representação esquemática dos tratamentos realizados em linfócitos de sangue periférico de pacientes com melanoma e controles, totalizando quinze microtubos por indivíduo 


\section{Critérios de Análise}

Para visualizar os danos no DNA com o teste do cometa, as lâminas foram analisadas em microscópio de fluorescência com filtro de excitação de 515-560nm e filtro de barreira de 590nm. Para cada tratamento, na avaliação da extensão e distribuição do dano ao DNA, foram consideradas 100 células não sobrepostas, selecionadas ao acaso. A análise foi qualitativa e os cometas classificados de 0 a 3 , considerando-se a morfologia das células a partir da avaliação do tamanho da cabeça, que corresponde ao DNA íntegro da célula (nucleóide) e tamanho da cauda, que corresponde ao DNA danificado. Em cada lâmina as células foram visualmente classificadas de acordo com o tamanho da cauda do cometa nas seguintes classes: Classe 0 - não danificada (não possui cauda); Classe 1 - dano pequeno (cauda: até 1 diâmetro do nucleóide); Classe 2 - dano médio (cauda: 1-2 diâmetros do nucleóide) e Classe 3 - dano máximo (cauda: maior que 2 diâmetros do nucleóide) - Figura 9. 


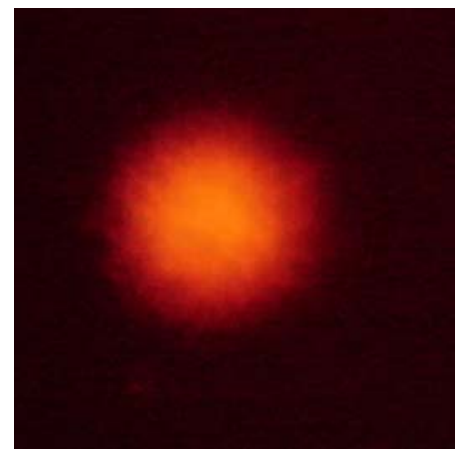

Classe 0

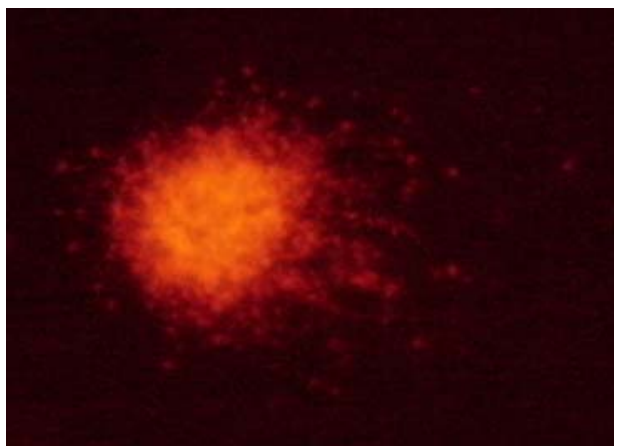

Classe 2

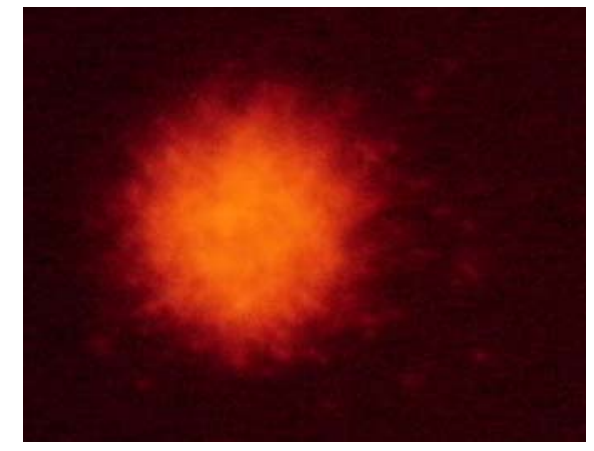

Classe 1

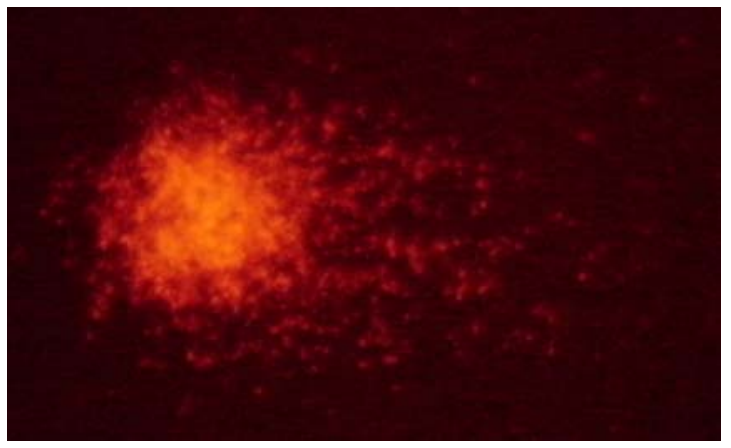

Classe 3

Figura 9: Fotos de Cometas visualizados nas culturas analisadas de pacientes com melanoma e controles, de acordo com a classificação de danos no DNA (aumento de 40X)

Após a classificação dos cometas em classes, foi calculado o escore, um valor numérico representativo do número de cometas em cada classe que variou de 0 a 300. Assim, para cada tratamento o escore correspondeu ao número total de cometas em cada classe multiplicado pelo número da classe, ou seja:

Escore $=\left(n^{\circ}\right.$ cel classe $\left.0 \times 0\right)+\left(n^{\circ}\right.$ cel classe $\left.1 \times 1\right)+\left(n^{\circ}\right.$ cel classe $\left.2 \times 2\right)+$ $\left(n^{\circ}\right.$ cel classe $\left.3 \times 3\right)$ 


\subsection{Análise Estatística}

As análises estatísticas foram realizadas utilizando os softwares SPSS 15.0 e SAS 8.0. Para avaliar as características fenotípicas e os hábitos pessoais foi utilizado o teste exato de Fisher (Bussab e Morettin, 1987) para determinar a associação entre a variabilidade dos grupos. Para o teste do Cometa, os escores médios de cada tratamento foram calculados e o teste ANOVA foi utilizado seguido pelo teste de Tukey (Neter et al., 1996). $\mathrm{Na}$ análise foram utilizados os escores médios de cada tratamento comparados com a frequência de Cometas no controle negativo (dano basal). Também foi considerada a ação da cisplatina após 1 hora de tratamento e o seu reparo, após uma hora, duas horas e meia e cinco horas. As análises foram interpretadas utilizando grau de significância de $5 \%$ $(p<0,05)$. 
4 RESUltados 


\subsection{Caracterização da População do Estudo}

Na presente investigação, 40 indivíduos participaram do estudo: 20 pacientes com diagnóstico de melanoma, de ambos os sexos e 20 indivíduos controles. No entanto, devido a fatores metodológicos no procedimento do experimento, a análise de um indivíduo controle não foi considerada por causa do reduzido número de células obtido. Os principais dados avaliados no questionário estão descritos na Tabela 1. Os dois grupos foram similares quanto ao gênero $(p=0,87)$ e faixa etária $(p=0,68)$.

Dentre os pacientes com melanoma, 10 indivíduos $(50,0 \%)$ eram do sexo masculino e $10(50,0 \%)$ do feminino, sendo que as idades variaram entre 38 e 59 anos (idade média $=50,6 \pm 6$ anos). Já no grupo controle, 9 indivíduos eram homens $(47,4 \%)$ e 10 mulheres $(52,6 \%)$, com idade média de 49,9 $\pm 5,5$ anos (Tabela 1 ).

Em relação às características fenotípicas, observou-se que $40 \%$ dos pacientes com melanoma apresentaram cor dos olhos claros (verdes ou azuis) em comparação com $21 \%$ dos controles, sendo que essa diferença não foi estatisticamente significante $(p=0,2)$. $O$ mesmo foi observado quanto à cor dos cabelos, em que $15 \%$ dos pacientes tinham cabelos claros (loiro ou ruivo) comparados a $5 \%$ do grupo controle $(p=0,6)$. Quanto à cor 
de pele, todos os pacientes com melanoma eram da cor branca (100\%) em comparação com $68 \%$ dos indivíduos controles, diferença essa estatisticamente significante com $p=0,008$ (Tabela 1). Os indivíduos classificados como cor de pele não branca foram identificados como de cor negra, mulatos e morenos.

Quando questionados os padrões de consumo de álcool (tipo de bebida e intensidade) e o uso de cigarros (número de anos e intensidade) verificamos que os padrões de consumo de ambos os hábitos foram semelhantes nos grupos, sem diferença estatisticamente significante, como demonstrado na Tabela 1 ( $p=0,58$ e $p=0,69$, respectivamente).

Quanto à sensibilidade à exposição solar verificamos que a mesma foi maior nos pacientes com melanoma $(90,0 \%)$, revelada pelo número anual de queimaduras de pele e vermelhidão, quando comparados ao grupo controle $(42,1 \%)$ sendo essa diferença considerada estatisticamente significante $(p=0,002)$.

No questionário aplicado, foi investigado o histórico de câncer na família, principalmente parentes de primeiro grau. No grupo dos pacientes com melanoma, $75 \%$ dos indivíduos tinham um membro da família próximo que teve algum tipo de câncer e no grupo controle, apenas 42,1\% tinha um histórico de câncer na família ( $p=0,04$ - Tabela 1). É interessante ressaltar que quatro pacientes (P3, P5, P8 e P11 - Tabela 5) informaram ter um parente que também foi diagnosticado com melanoma. 
Tabela 1: Distribuição dos pacientes com melanoma e controles de acordo com o sexo, idade, características fenotípicas, hábitos de bebida e fumo, sensibilidade à exposição solar e história de câncer na família

\begin{tabular}{|c|c|c|c|}
\hline & $\begin{array}{c}\text { Pacientes } \\
20(\%)\end{array}$ & $\begin{array}{c}\text { Controles } \\
19(\%)\end{array}$ & $\mathbf{P}$ \\
\hline Sexo & & & 0,87 \\
\hline Masculino & $10(50,0)$ & $9(47,4)$ & \\
\hline Feminino & $10(50,0)$ & $10(52,6)$ & \\
\hline Idade média \pm dp (anos) & & & 0,68 \\
\hline Homens & $52,6 \pm 6,5$ & $50,8 \pm 5,6$ & \\
\hline Mulheres & $48,7 \pm 4,9$ & $49,1 \pm 5,6$ & \\
\hline Total & $50,6 \pm 5,9$ & $49,9 \pm 5,5$ & \\
\hline Cor dos olhos & & & 0,20 \\
\hline Castanho claro/escuro & $12(60,0)$ & $15(78,9)$ & \\
\hline Azul/verde & $8(40,0)$ & $4(21,1)$ & \\
\hline Cor dos cabelos & & & 0,60 \\
\hline Castanho claro/escuro & $17(85,0)$ & $18(94,7)$ & \\
\hline Loiro/ruivo & $3(15,0)$ & $1(5,3)$ & \\
\hline Cor da pele & & & $0,008^{*}$ \\
\hline Branca & $20(100,0)$ & $13(68,4)$ & \\
\hline Não branca & $0(0,0)$ & $6(31,6)$ & \\
\hline Consumo de álcool & & & 0,58 \\
\hline Não & $12(60,0)$ & $11(57,9)$ & \\
\hline Sim & $4(20,0)$ & $6(31,6)$ & \\
\hline Ex-consumidor & $4(20,0)$ & $2(10,5)$ & \\
\hline Consumo de tabaco & & & 0,69 \\
\hline Não & $13(65,0)$ & $11(57,9)$ & \\
\hline Sim & $3(15,0)$ & $2(10,5)$ & \\
\hline Ex-fumante & $4(20,0)$ & $6(31,6)$ & \\
\hline Queimaduras solares & & & $0,002^{*}$ \\
\hline Não & $2(10,0)$ & $11(57,9)$ & \\
\hline Sim & $18(90,0)$ & $8(42,1)$ & \\
\hline História de câncer & & & $0,04^{*}$ \\
\hline Não & $5(25,0)$ & $11(57,9)$ & \\
\hline Sim & $15(75,0)$ & $8(42,1)$ & \\
\hline
\end{tabular}

*diferença considerada estatisticamente significante

dp: desvio padrão 


\subsection{Caracterização do Tumor nos Pacientes com Melanoma}

A Tabela 2 apresenta a distribuição das características do tumor diagnosticado nos pacientes com melanoma, de acordo com a classificação do estadiamento de Clark e espessura da lesão de acordo com a medida de Breslow. Atualmente, o índice de Breslow é o mais utilizado na classificação dos tumores de melanoma, no entanto, como a maioria dos laudos hospitalares também apresentava a classificação de Clark, os dois índices foram apresentados.

Alguns dados dos pacientes recrutados não foram possíveis de se obter, por isso as informações se referem somente aos laudos histopatológicos de 17 pacientes. O tratamento indicado a todos os pacientes foi remoção cirúrgica, sendo que em relação à classificação de Clark, observa-se que $35,3 \%$ dos tumores que foram removidos estavam invadindo a derme reticular e que apenas $5,9 \%$ dos tumores apresentaram invasão do tecido subcutâneo. Quanto à espessura do tumor, aproximadamente $43 \%$ dos pacientes teve remoção de tumor que media menos de 1,0 mm (Tabela 2). 
Tabela 2: Distribuição das características histopatológicas do tumor de pacientes com melanoma, segundo a classificação de Clark e índice de Breslow

\begin{tabular}{lcc}
\hline \multicolumn{1}{c}{ Variável } & N & $\%$ \\
\hline Clark & $\mathbf{1 7}$ & \\
I - Displasia Melanocítica Severa / crescimento intra-dérmico & 3 & 17,6 \\
II - Invasão da derme papilar & 3 & 17,6 \\
III - Invasão da transição derme papilar/reticular & 4 & 23,5 \\
IV - Invasão da derme reticular & 6 & 35,3 \\
V - Invasão do tecido celular subcutâneo & 1 & 5,9 \\
Breslow & 14 & \\
I - Espessura do tumor $\leq 1,0 \mathrm{~mm}$ & 6 & 42,9 \\
II - Espessura do tumor $=1,1$ - 2,0 mm & 5 & 35,7 \\
III - Espessura do tumor $=2,1$ - 4,0 mm & 2 & 14,3 \\
IV - Espessura do tumor $>4,0 \mathrm{~mm}$ & 1 & 7,1 \\
\hline
\end{tabular}

\subsection{Testes Citogenéticos}

\subsubsection{Teste do MN}

O teste do micronúcleo (MN) foi realizado em 19 indivíduos, sendo 10 pacientes com melanoma e 9 controles. Os pacientes eram 6 indivíduos do sexo masculino (51,5 $\pm 7,7$ anos) e 4 do sexo feminino $(51,5 \pm 4,9$ anos) e o

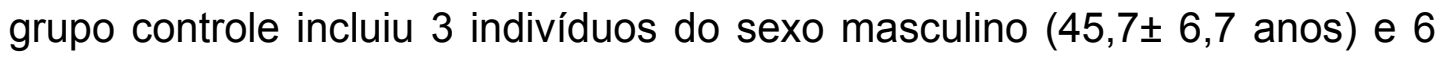
do sexo feminino $(50,0 \pm 6,3$ anos $)$.

Foram analisados 1000 linfócitos binucleados por indivíduo, totalizando ao final 19.000 células analisadas. $\mathrm{Na}$ análise do $\mathrm{MN}$ foi contabilizado o número de células com $\mathrm{MN}$ e o número de $\mathrm{MN}$ por célula 
binucleada. Na presente investigação, todas as células analisadas apresentaram somente um $\mathrm{MN}$, sendo que ao final o número de $\mathrm{MN}$ por célula foi o mesmo que o número de células com $\mathrm{MN}$.

A Tabela 3 apresenta a distribuição do sexo, da idade e do número de células com MN dos pacientes com melanoma e dos controles.

Tabela 3: Sexo, idade e frequência de linfócitos binucleados com MN observada nos pacientes $(P)$ com melanoma e nos controles $(C)$

\begin{tabular}{cccc}
\hline & sexo & idade & células com MN \\
\cline { 2 - 4 } Pacientes & & & 3 \\
P1 & F & 57 & 2 \\
P3 & M & 57 & 0 \\
P4 & F & 54 & 0 \\
P5 & M & 52 & 1 \\
P6 & M & 59 & 0 \\
P12 & F & 49 & 0 \\
P13 & F & 46 & 2 \\
P14 & M & 55 & 3 \\
P15 & M & 48 & 1 \\
P16 & M & 38 & $1,2 \pm 1,2$ \\
Média \pm dp & & $51,5 \pm 6,4$ & \\
\hline
\end{tabular}

\section{Controles}

$\begin{array}{lccc}\text { C3 } & \text { F } & 57 & 1 \\ \text { C5 } & \text { F } & 51 & 3 \\ \text { C7 } & F & 51 & 0 \\ \text { C9 } & \text { F } & 38 & 0 \\ \text { C11 } & \text { F } & 51 & 0 \\ \text { C13 } & \text { F } & 52 & 0 \\ \text { C14 } & \text { M } & 40 & 0 \\ \text { C15 } & \text { M } & 53 & 0 \\ \text { C16 } & \text { M } & 44 & 1 \\ \text { dia } \pm \text { dp } & & 48,6 \pm 6,4 & 0,6 \pm 1,0\end{array}$

M: masculino, F: feminino; dp: desvio padrão 
Verificou-se que a média de células com MN encontrada nos pacientes com melanoma $(1,2 \pm 1,2)$ foi o dobro da observada nos controles $(0,6 \pm 1,0)$, no entanto, esta diferença não foi considerada estatisticamente significante $(p=0,23)$. No grupo dos pacientes $60 \%$ dos indivíduos apresentou pelo menos uma célula com $\mathrm{MN}$, enquanto que nos controles isto foi observado apenas em $33,3 \%$.

Se considerarmos em conjunto o grupo de pacientes com melanoma e o grupo controle verificamos que nos pacientes com melanoma foram identificadas 12 células binucleadas com MN e apenas 5 células no grupo controle, conforme apresentado na Tabela 4. O grupo dos pacientes apresentou mais que o dobro de MN em relação aos controles, no entanto, a análise estatística pelo teste qui-quadrado não revelou diferença significante na frequência de MN observada nos indivíduos $(p=0,22)$.

Tabela 4: Frequência de células binucleadas com $\mathrm{MN}$ observada nos pacientes com melanoma e no grupo controle

\begin{tabular}{ccccc}
\hline & $\mathbf{N}$ & $\begin{array}{c}\text { células } \\
\text { analisadas }\end{array}$ & $\begin{array}{c}\text { células } \\
\text { com MN (\%) }\end{array}$ & $\mathbf{P}$ \\
\cline { 2 - 4 } pacientes & 10 & 10.000 & $12(1,2)$ & 0,22 \\
controles & 9 & 9.000 & $5(0,6)$ & \\
Total & 19 & 19.000 & $17(0,9)$ & \\
\hline
\end{tabular}




\subsubsection{Teste do Cometa}

A avaliação do teste do Cometa totalizou na análise de 58.500 células que foram classificadas de 0 a 3, dependendo do tamanho da cauda gerada, e resultou em escores, que variaram de 2 a 277 , que serão apresentados a seguir.

As Tabelas 5 e 6 apresentam o sexo, a idade e os escores obtidos a partir da análise de linfócitos sem tratamento (dano basal), linfócitos tratados com $\mathrm{H}_{2} \mathrm{O}_{2} 30 \mathrm{~V}$ por uma hora (controle positivo) e linfócitos tratados com $\mathrm{H}_{2} \mathrm{O}_{2}$ $(10 \mu \mathrm{M})$ por 5 minutos (tratamento necessário para ruptura dos crosslinks formados após a adição de cisplatina). Nas mesmas tabelas são também apresentados os escores observados após adição de cisplatina, em três concentrações diferentes $(10 \mu \mathrm{M}, 100 \mu \mathrm{M}$ e $250 \mu \mathrm{M})$, em culturas de linfócitos de pacientes com melanoma e de controles.

$\mathrm{Na}$ Tabela 5, verificou-se que a média do escore relativo ao dano basal observada nos pacientes com melanoma $(59,3 \pm 62,5)$ foi praticamente o dobro da observada nos indivíduos controle (35,3 \pm 18,6 - Tabela 6), embora não tenha sido uma diferença considerada estatisticamente significante entre os grupos pela análise de variância com medidas repetidas $(t=1,59 ; 147 \mathrm{gl} ; \mathrm{p}=0,85)$.

A identificação de resposta dos linfócitos testados a agentes potencialmente mutagênicos foi feita por meio da adição de peróxido de hidrogênio (30V), por uma hora, nas culturas de linfócitos. Quando comparados os grupos testados confirmamos a ação mutagênica do controle 
positivo tanto para os pacientes com melanoma onde houve um efeito praticamente 3,5 vezes maior na produção de Cometas $(\mathrm{t}=8,4 ; 37 \mathrm{gl}$; $p<0,0001$ - Tabela 5), como para os indivíduos controle, onde a diferença entre dano basal $(35,3 \pm 18,6)$ e controle positivo $(194,2 \pm 37,0)$ foi praticamente cinco vezes maior ( $t=16,7 ; 36 \mathrm{gl}$; $\mathrm{p}<0,0001)$, conforme apresentado na Tabela 6. No entanto, quando comparados os escores médios do controle positivo dos pacientes com melanoma $(201,5 \pm 40,0)$ e dos indivíduos controles $(194,2 \pm 37,0)$, a diferença entre eles não foi considerada estatisticamente significante $(t=0,58 ; 36 \mathrm{gl} ; \mathrm{p}=0,56)$.

A adição de $\mathrm{H}_{2} \mathrm{O}_{2}$ na concentração de $(10 \mu \mathrm{M})$ por 5 minutos, produziu um escore inferior ao observado na cultura controle positiva, tanto para os casos como para os controles. A adição de $\mathrm{H}_{2} \mathrm{O}_{2}$ não alterou de forma significante a frequência de Cometas nos pacientes com melanoma $(83,3 \pm 60,7)$ quando comparados com o dano observado nos linfócitos sem tratamento $(\mathrm{t}=1,20 ; 36 \mathrm{gl} ; \mathrm{p}=0,24-$ Tabela 5$)$. Resultados diferentes foram observados para o grupo controle $(78,6 \pm 24,5)$, que na presença de $\mathrm{H}_{2} \mathrm{O}_{2}$ $(10 \mu \mathrm{M})$ revelou diferença significante $(t=5,96 ; 34 \mathrm{gl} ; \mathrm{p}<0,0001$ - Tabela 6$)$ na comparação da frequência de Cometas observada nas culturas sem tratamento. Comparando os escores médios dos pacientes $(83,3 \pm 60,7)$ e controles $(78,6 \pm 24,5)$, não houve diferença estatisticamente significante $(t=0,30 ; 34 \mathrm{gl} ; p=0,76)$. 
Tabela 5: Distribuição dos 20 pacientes com melanoma quanto ao sexo, idade e frequência de Cometas revelado pelo escore final das culturas sem tratamento (dano basal), culturas tratadas com $\mathrm{H}_{2} \mathrm{O}_{2}(30 \mathrm{~V})$ por uma hora (controle positivo) e culturas tratadas com $\mathrm{H}_{2} \mathrm{O}_{2}(10 \mu \mathrm{M})$ por 5 minutos além dos tratamentos, in vitro, com cisplatina em três concentrações diferentes $(10 \mu \mathrm{M}, 100 \mu \mathrm{M}$ e $250 \mu \mathrm{M})$

\begin{tabular}{|c|c|c|c|c|c|c|c|c|}
\hline \multirow{2}{*}{ Pacientes } & \multirow{2}{*}{ Sexo } & \multirow{2}{*}{$\begin{array}{l}\text { Idade } \\
\text { (anos) }\end{array}$} & \multirow{2}{*}{ Dano basal } & \multirow{2}{*}{ Controle + } & \multirow{2}{*}{$\mathrm{H}_{2} \mathrm{O}_{2}(5 \mathrm{~min})$} & \multicolumn{3}{|c|}{ Cisplatina } \\
\hline & & & & & & $10 \mu \mathrm{M}$ & $100 \mu \mathrm{M}$ & $250 \mu \mathrm{M}$ \\
\hline P1 & $\mathrm{F}$ & 57 & 137 & 269 & 144 & 186 & 136 & 144 \\
\hline P2 & $M$ & 56 & 118 & 277 & 139 & 80 & 71 & 96 \\
\hline P3 & $M$ & 57 & 28 & 202 & 61 & 58 & 84 & 82 \\
\hline P4 & $\mathrm{F}$ & 54 & 18 & 195 & 29 & 20 & 29 & 68 \\
\hline P5 & $M$ & 52 & 38 & 193 & 102 & 44 & 70 & 51 \\
\hline P6 & $\mathrm{M}$ & 59 & 19 & 172 & 20 & 33 & 46 & 45 \\
\hline P7 & $\mathrm{F}$ & 50 & 2 & 173 & 12 & 13 & 21 & 29 \\
\hline P8 & $M$ & 48 & 29 & 159 & 67 & 34 & 42 & 30 \\
\hline P9 & $\mathrm{F}$ & 40 & 91 & 169 & 103 & 122 & 61 & 93 \\
\hline P10 & $\mathrm{F}$ & 48 & 14 & 120 & 77 & 36 & 16 & 32 \\
\hline P11 & $\mathrm{F}$ & 51 & 8 & 221 & 57 & 44 & 39 & 40 \\
\hline P12 & $\mathrm{F}$ & 49 & 17 & 202 & 47 & 20 & 44 & 78 \\
\hline P13 & $\mathrm{F}$ & 46 & 75 & 207 & - & 55 & 79 & 55 \\
\hline P14 & $M$ & 55 & 42 & 185 & - & 55 & 84 & 77 \\
\hline P15 & $M$ & 48 & 218 & 269 & 221 & 116 & 214 & - \\
\hline P16 & $M$ & 38 & 196 & - & 210 & 182 & 170 & 213 \\
\hline P17 & $M$ & 54 & 63 & 231 & 81 & 88 & - & 80 \\
\hline P18 & $\mathrm{F}$ & 43 & 14 & 170 & 31 & 33 & 73 & 86 \\
\hline P19 & $F$ & 49 & 31 & 213 & 59 & 55 & 66 & 108 \\
\hline $\begin{array}{c}\text { P20 } \\
\text { Média } \pm \text { dp }\end{array}$ & $M$ & $\begin{array}{c}59 \\
50,6 \pm 5,9\end{array}$ & $\begin{array}{c}28 \\
59,3 \pm 62,5\end{array}$ & $\begin{array}{c}201 \\
201,5 \pm 40,0^{a}\end{array}$ & $\begin{array}{c}39 \\
83,3 \pm 60,7^{b}\end{array}$ & $\begin{array}{c}36 \\
65,50 \pm 50,06^{c}\end{array}$ & $\begin{array}{c}37 \\
72,74 \pm 50,89^{d}\end{array}$ & $\begin{array}{c}61 \\
77,26 \pm 44,16^{\mathrm{e}}\end{array}$ \\
\hline
\end{tabular}

M: masculino, F: feminino; dp: desvio padrão; a: diferença considerada estatisticamente significante em relação à média do escore do dano basal ( $p<0,0001) ; \mathbf{b}, \mathbf{c}, \mathbf{d}$, e: comparações dos escores com o escore do dano basal resultaram em diferenças consideradas estatisticamente não significantes: b: $(p=0,24)$; $\mathbf{c}(p=0,73) ; \mathbf{d}:(p=0,47) ; \mathbf{e}:(p=0,31)$. 
Tabela 6: Distribuição dos 19 indivíduos controle quanto ao sexo, idade e frequência de Cometas revelado pelo escore final das culturas sem tratamento (dano basal), culturas tratadas com $\mathrm{H}_{2} \mathrm{O}_{2}(30 \mathrm{~V})$ por uma hora (controle positivo) e culturas tratadas com $\mathrm{H}_{2} \mathrm{O}_{2}(10 \mu \mathrm{M})$ por 5 minutos além dos tratamentos, in vitro, com cisplatina em três concentrações diferentes $(10 \mu \mathrm{M}, 100 \mu \mathrm{M}$ e $250 \mu \mathrm{M})$

\begin{tabular}{|c|c|c|c|c|c|c|c|c|}
\hline \multirow{2}{*}{ Controles } & \multirow{2}{*}{ Sexo } & \multirow{2}{*}{$\begin{array}{l}\text { Idade } \\
\text { (anos) }\end{array}$} & \multirow{2}{*}{$\begin{array}{l}\text { Dano } \\
\text { basal }\end{array}$} & \multirow{2}{*}{ Controle + } & \multirow{2}{*}{$\mathrm{H}_{2} \mathrm{O}_{2}(5 \mathrm{~min})$} & \multicolumn{3}{|c|}{ Cisplatina } \\
\hline & & & & & & $10 \mu \mathrm{M}$ & $100 \mu \mathrm{M}$ & $250 \mu \mathrm{M}$ \\
\hline C1 & $M$ & 52 & 11 & 121 & 101 & 34 & 51 & 98 \\
\hline $\mathrm{C} 2$ & M & 49 & 41 & 176 & 89 & 50 & 43 & 102 \\
\hline C3 & $\mathrm{F}$ & 57 & 42 & 242 & 87 & 120 & 112 & 198 \\
\hline C4 & $\mathrm{F}$ & 52 & 83 & 166 & 103 & 60 & 70 & 116 \\
\hline C5 & $\mathrm{F}$ & 51 & 42 & 204 & 66 & 76 & 66 & 61 \\
\hline C6 & $M$ & 57 & 22 & 214 & 52 & 20 & 58 & 43 \\
\hline C7 & $\mathrm{F}$ & 51 & 18 & 192 & 44 & 37 & 32 & 42 \\
\hline C8 & $M$ & 55 & 9 & 146 & 40 & 25 & 41 & 11 \\
\hline $\mathrm{C} 9$ & $\mathrm{~F}$ & 38 & 16 & 180 & 100 & 45 & 25 & 33 \\
\hline C10 & $\mathrm{F}$ & 49 & 52 & 151 & 95 & 54 & 70 & 110 \\
\hline C11 & $\mathrm{F}$ & 51 & 45 & 178 & 58 & 55 & 58 & 82 \\
\hline C12 & $\mathrm{F}$ & 41 & 16 & 218 & 65 & 60 & 94 & 72 \\
\hline C13 & $\mathrm{F}$ & 52 & 32 & 229 & 84 & 77 & 72 & 64 \\
\hline C14 & $M$ & 40 & 36 & 220 & 63 & 52 & 58 & 53 \\
\hline C15 & $M$ & 53 & 31 & 223 & - & 51 & 87 & 99 \\
\hline C16 & $M$ & 44 & - & 269 & 134 & 248 & 131 & 143 \\
\hline C17 & $M$ & 56 & 54 & 219 & 99 & 86 & 78 & 93 \\
\hline C18 & $\mathrm{F}$ & 49 & 35 & 181 & 68 & 37 & 69 & 83 \\
\hline C19 & $M$ & 51 & 51 & 161 & 66 & 77 & 49 & 50 \\
\hline Média \pm dp & & $49,9 \pm 5,5$ & $35,33 \pm 18,63$ & $194,2 \pm 37,0^{a}$ & $78,6 \pm 24,5^{b}$ & $66,53 \pm 49,85^{c}$ & $66,53 \pm 26,33^{d}$ & $81,74 \pm 43,12^{\mathrm{e}}$ \\
\hline
\end{tabular}

M: masculino, F: feminino; dp: desvio padrão; a, b, c, d, e: comparações dos escores com o escore do dano basal resultaram em diferenças consideradas estatisticamente significantes: $\mathbf{a} ; \mathbf{b}:(p<0,0001) ; \mathbf{c}:(p=0,0175) ; \mathbf{d} ; \mathbf{e}:(p=0,0002)$. 
A análise posterior incluiu a identificação de possíveis danos no DNA após a adição de cisplatina. Os pacientes com melanoma apresentaram um crescimento linear na formação de Cometas, indicando um possível aumento do dano dependente da concentração da droga, que variou de 65,5 \pm 50,1 a 77,3 \pm 44,2 (Tabela 5). O mesmo não foi observado no grupo controle, onde somente a exposição a $250 \mu \mathrm{M}$ de cisplatina aumentou o escore $(81,7 \pm 43,1)$ em relação às demais concentrações de $10 \mu \mathrm{M}(66,5 \pm 49,8)$ e $100 \mu \mathrm{M}(66,5 \pm 26,3)$, como demonstrado na Tabela 6 . Em ambos os grupos não houve diferença estatisticamente significante entre a frequência de Cometas observada nas três concentrações da cisplatina testadas e nem entre pacientes e controles, após tratamento. Comparando o dano basal com as diferentes concentrações de cisplatina, observou-se que no grupo controle houve diferença em relação a todas as concentrações avaliadas: $10 \mu \mathrm{M}(\mathrm{t}=2,5 ; 35 \mathrm{gl} ; \mathrm{p}=0,0175), 100 \mu \mathrm{M}(\mathrm{t}=4,1 ; 35 \mathrm{gl} ; \mathrm{p}=0,0002)$ e $250 \mu \mathrm{M}$ $(\mathrm{t}=4,2 ; 35 \mathrm{gl} ; \mathrm{p}=0,0002)$, conforme apresentado na Tabela 6 . O mesmo não foi observado nos pacientes, sendo que a comparação entre o dano basal e as três concentrações de cisplatina não foi considerada estatisticamente significante (Tabela 5).

Todas as culturas testadas com diferentes concentrações de cisplatina, após uma hora de tratamento, foram lavadas com meio de cultura sem a droga e mantidas a $37^{\circ} \mathrm{C}$ por tempos que variaram de 1 a 5 horas. A Tabela 7 apresenta o escore médio de Cometas observado nos linfócitos de pacientes e controles que foram submetidos ao processo de reparo, in vitro, após a retirada da cisplatina. Verificou-se que os escores médios do 
grupo controle foram maiores quando comparados ao grupo dos pacientes com melanoma, em praticamente todos os tempos considerados para a avaliação do reparo do DNA, embora a diferença não tenha sido considerada estatisticamente significante quando os dois grupos foram comparados (Tabela 7).

Tabela 7: Comparação da média dos escores avaliados pelo teste do Cometa em linfócitos de 20 pacientes e 19 indivíduos controle após exposição in vitro a $10 \mu \mathrm{M}, 100 \mu \mathrm{M}$ e $250 \mu \mathrm{M}$ de cisplatina e reparo do DNA, sem a droga, por $1 \mathrm{~h}, 2,5 \mathrm{~h}$ e $5 \mathrm{~h}$

\begin{tabular}{|c|c|c|c|c|c|c|}
\hline Cisplatina & $\begin{array}{r}\text { Reparo } \\
\text { do DNA }\end{array}$ & $\begin{array}{l}\text { Pacientes com } \\
\text { Melanoma }\end{array}$ & Controles & $\mathbf{t}$ & gl & $\mathbf{P}$ \\
\hline \multirow{3}{*}{$10 \mu \mathrm{M}$} & 1h & $82,8 \pm 23,6$ & $90,9 \pm 50,1$ & 0,63 & 35 & 0,529 \\
\hline & $2,5 h$ & $99,8 \pm 38,4$ & $107,4 \pm 39,3$ & 0,59 & 34 & 0,561 \\
\hline & $5 \mathrm{~h}$ & $102,3 \pm 31,9$ & $104,4 \pm 29,5$ & 0,2 & 34 & 0,842 \\
\hline \multirow{3}{*}{$100 \mu \mathrm{M}$} & 1h & $89,9 \pm 23,4$ & $93,2 \pm 34,3$ & 0,35 & 37 & 0,725 \\
\hline & $2,5 h$ & $109,0 \pm 35,2$ & $93,2 \pm 33,4$ & 1,38 & 34 & 0,177 \\
\hline & $5 h$ & $96,1 \pm 33,4$ & $99,6 \pm 34,1$ & 0,31 & 34 & 0,758 \\
\hline \multirow{3}{*}{$250 \mu \mathrm{M}$} & 1h & $108,4 \pm 45,0$ & $93,2 \pm 30,5$ & 1,2 & 36 & 0,237 \\
\hline & $2,5 h$ & $96,7 \pm 34,1$ & $101,7 \pm 43,7$ & 0,4 & 36 & 0,693 \\
\hline & $5 h$ & $99,5 \pm 33,0$ & $98,4 \pm 32,8$ & 0,09 & 35 & 0,925 \\
\hline
\end{tabular}

gl: grau de liberdade 
A comparação entre a frequência de Cometas observada nas culturas sem tratamento, dos pacientes e dos controles, e as frequências de Cometas observadas após os diferentes tempos de reparo também foram consideradas. A Tabela 8 apresenta a relação entre o dano basal e os tempos de reparo, dos pacientes e controles, considerando em conjunto as três concentrações de cisplatina, já que não houve diferença estatística entre os escores. Observou-se que em ambos os grupos as diferenças foram consideradas estatisticamente significantes, com $p<0,001$, conforme apresentado na Tabela 8.

Tabela 8: Análise de comparações múltiplas de Tukey (147 gl) para o teste do Cometa entre os valores do dano basal, observados em linfócitos de pacientes com melanoma e indivíduos controle, e os tempos de reparo ( $1 \mathrm{~h}, 2,5 \mathrm{~h}$ e $5 \mathrm{~h})$

\begin{tabular}{|c|c|c|c|c|c|}
\hline Dano basal & $\begin{array}{c}\text { Tempo } \\
\text { de Reparo }\end{array}$ & $\begin{array}{l}\text { Escore } \\
\text { médio }\end{array}$ & $\begin{array}{l}\text { Diferença } \\
\text { média }\end{array}$ & $\mathbf{t}$ & $\mathbf{p}$ \\
\hline \multirow{3}{*}{$\begin{array}{c}\text { Pacientes } \\
(59,30 \pm 62,5)\end{array}$} & $1 \mathrm{~h}$ & $93,88 \pm 33,7$ & 35,57 & 4,91 & $<0,001^{*}$ \\
\hline & $2,5 \mathrm{~h}$ & $101,75 \pm 35,7$ & 42,21 & 5,76 & $<0,001^{*}$ \\
\hline & $5 \mathrm{~h}$ & $99,31 \pm 32,30$ & 40,9 & 5,59 & $<0,001^{*}$ \\
\hline \multirow{3}{*}{$\begin{array}{c}\text { Controles } \\
(35,33 \pm 18,6)\end{array}$} & $1 \mathrm{~h}$ & $92,45 \pm 38,4$ & 52,81 & 6,93 & $<0,001^{*}$ \\
\hline & $2,5 \mathrm{~h}$ & $100,82 \pm 38,8$ & 61,32 & 8,05 & $<0,001^{*}$ \\
\hline & $5 \mathrm{~h}$ & $100,81 \pm 31,7$ & 61,89 & 8,1 & $<0,001^{*}$ \\
\hline
\end{tabular}

* diferença considerada estatisticamente significante 
A Tabela 9 apresenta a comparação entre os escores relativos ao tratamento com as diferentes concentrações de cisplatina, consideradas em conjunto, e os tempos de reparo, dos pacientes e controles. Observou-se, novamente, que em ambos os grupos as diferenças foram consideradas estatisticamente significantes, com $p \leq 0,005$.

Tabela 9: Análise de comparações múltiplas de Tukey (147 gl) para o teste do Cometa entre os valores do tratamento com cisplatina, observados em linfócitos de pacientes com melanoma e indivíduos controle, e os tempos de reparo (1h, 2,5h e $5 \mathrm{~h}$ )

\begin{tabular}{|c|c|c|c|c|c|}
\hline $\begin{array}{c}\text { Tratamento } \\
\text { cisplatina }\end{array}$ & $\begin{array}{c}\text { Tempo } \\
\text { de Reparo }\end{array}$ & $\begin{array}{l}\text { Escore } \\
\text { médio }\end{array}$ & $\begin{array}{l}\text { Diferença } \\
\text { média }\end{array}$ & $\mathbf{t}$ & $\mathbf{p}$ \\
\hline \multirow{3}{*}{$\begin{array}{c}\text { Pacientes } \\
(71,09 \pm 48,2)\end{array}$} & $1 \mathrm{~h}$ & $93,88 \pm 33,7$ & 22,16 & 4,27 & $0,001^{*}$ \\
\hline & $2,5 \mathrm{~h}$ & $101,75 \pm 35,7$ & 28,79 & 5,45 & $<0,001^{*}$ \\
\hline & $5 \mathrm{~h}$ & $99,31 \pm 32,30$ & 27,49 & 5,2 & $<0,001^{*}$ \\
\hline \multirow{3}{*}{$\begin{array}{l}\text { Controles } \\
(71,59 \pm 40,5)\end{array}$} & $1 \mathrm{~h}$ & $92,45 \pm 38,4$ & 20,87 & 3,94 & $0,005^{*}$ \\
\hline & $2,5 \mathrm{~h}$ & $100,82 \pm 38,8$ & 29,38 & 5,55 & $<0,001^{*}$ \\
\hline & $5 \mathrm{~h}$ & $100,81 \pm 31,7$ & 29,95 & 5,62 & $<0,001^{*}$ \\
\hline
\end{tabular}

* diferença considerada estatisticamente significante 
A representação gráfica dos resultados obtidos em todas as análises para os pacientes com melanoma e os controles, encontra-se na Figura 10. Verificamos de forma conjunta que os dois grupos estudados apresentaram comportamentos semelhantes nos diferentes tratamentos, sendo que a diferença entre eles em relação às diferentes concentrações de cisplatina e tempos de reparo do DNA não foi estatisticamente significante pelo teste ANOVA $(F=0,22 ; p=0,64)$.

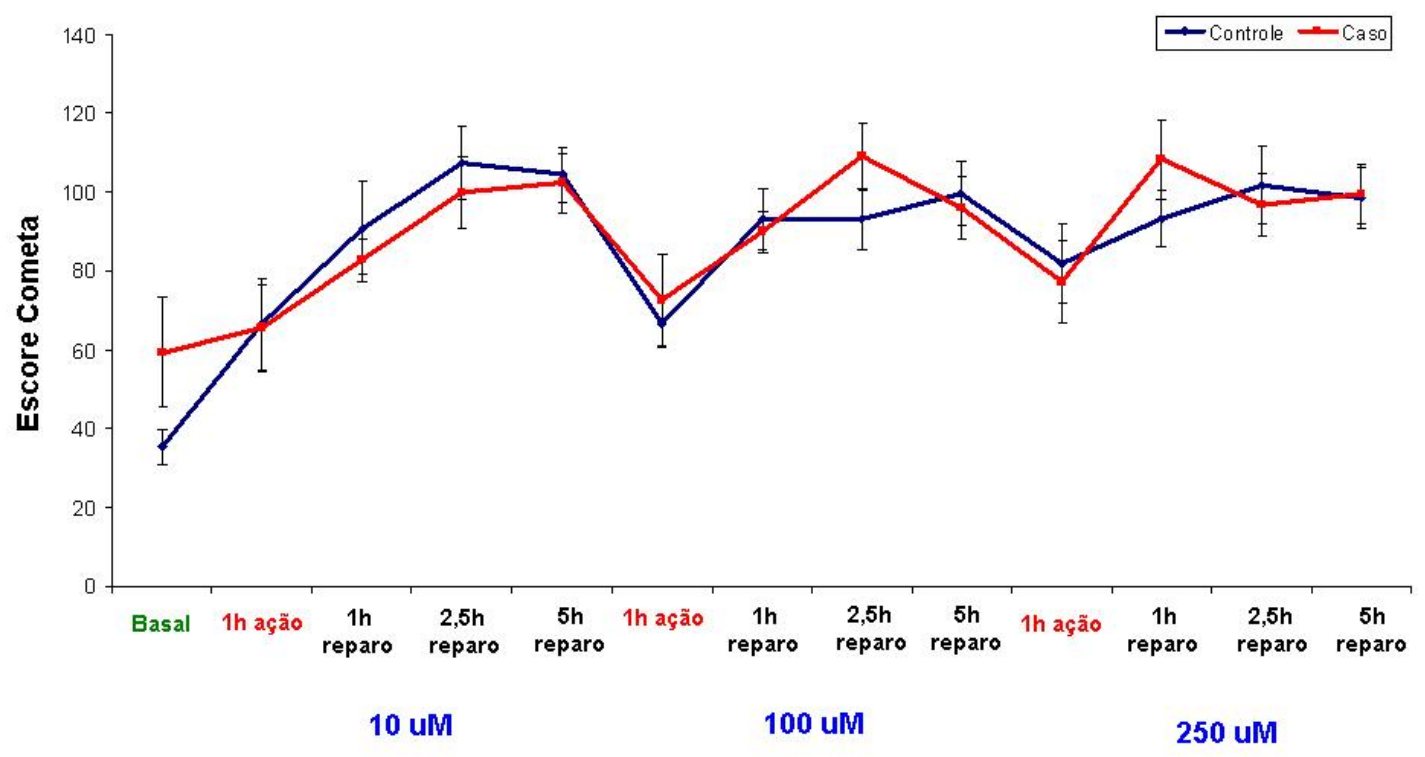

Concentração da Cisplatina / Tempo

Figura 10: Médias dos escores do Cometa do grupo controle e dos pacientes com melanoma em diferentes tempos e concentrações da cisplatina. O dano basal corresponde aos linfócitos sem tratamento com cisplatina 
Considerando que não houve diferença estatisticamente significante entre os grupos em relação aos danos no DNA, após a exposição à cisplatina em diferentes concentrações, e também nos diferentes tempos de reparo, foi efetuada a análise estatística considerando-se os dois grupos em conjunto (Tabela 10). Quando os três tratamentos com cisplatina e o reparo foram comparados com a frequência de Cometas observada nos linfócitos sem tratamento as diferenças foram todas estatisticamente significantes $(p \leq 0,001)$, com exceção apenas das comparações entre o dano basal com o tratamento de $1 \mathrm{~h}$ de exposição à cisplatina nas concentrações de $10 \mu \mathrm{M}$ e $100 \mu \mathrm{M}(\mathrm{p}=0,48$ e $p=0,16$, respectivamente).

Tabela 10: Análise de comparações múltiplas de Tukey (169 gl) para o teste do Cometa entre os valores do dano basal, considerando-se em conjunto os resultados observados nos pacientes e indivíduos controle, quanto aos tratamentos com cisplatina $(10 \mu \mathrm{M}, 100 \mu \mathrm{M}$ e $250 \mu \mathrm{M})$ e em diferentes tempos de reparo ( $1 \mathrm{~h}, 2,5 \mathrm{~h}$ e $5 \mathrm{~h})$

\begin{tabular}{|c|c|c|c|c|c|c|}
\hline & $\begin{array}{r}\text { Concentração } \\
\text { de cisplatina }\end{array}$ & $\begin{array}{c}\text { Tratamento } \\
\text { e tempos de } \\
\text { reparo } \\
\end{array}$ & $\begin{array}{l}\text { Escore } \\
\text { médio }\end{array}$ & $\begin{array}{l}\text { Diferença } \\
\text { média }\end{array}$ & $\mathbf{t}$ & $\mathbf{P}$ \\
\hline & \multirow{4}{*}{$10 \mu \mathrm{M}$} & 1h ação & $66,0 \pm 49,28$ & 16,08 & 2,46 & 0,476 \\
\hline & & 1h reparo & $86,73 \pm 38,46$ & 38,45 & 5,79 & $<0,001^{*}$ \\
\hline & & $2,5 \mathrm{~h}$ reparo & $103,64 \pm 38,50$ & 53,67 & 8,03 & $<0,001^{*}$ \\
\hline & & $5 \mathrm{~h}$ reparo & $103,36 \pm 30,32$ & 53,96 & 8,07 & $<0,001^{*}$ \\
\hline \multirow{8}{*}{$\begin{array}{c}\text { Dano Basal } \\
(47,95 \pm 48,08)\end{array}$} & & 1h ação & $69,63 \pm 40,09$ & 19,82 & 3,01 & 0,161 \\
\hline & $100 \mu \mathrm{M}$ & 1h reparo & $91,51 \pm 28,86$ & 41,6 & 6,36 & $<0,001^{*}$ \\
\hline & & $2,5 \mathrm{~h}$ reparo & $101,11 \pm 34,77$ & 51,35 & 7,68 & $<0,001^{*}$ \\
\hline & & $5 \mathrm{~h}$ reparo & $97,86 \pm 33,33$ & 49,7 & 7,44 & $<0,001^{*}$ \\
\hline & & 1h ação & $79,5 \pm 43,11$ & 31,11 & 4,72 & $0,001^{*}$ \\
\hline & $250 \mu \mathrm{M}$ & 1h reparo & $101,21 \pm 39,08$ & 51,34 & 7,79 & $<0,001^{*}$ \\
\hline & & $2,5 \mathrm{~h}$ reparo & $99,21 \pm 38,75$ & 49,4 & 7,5 & $<0,001^{*}$ \\
\hline & & 5h reparo & $98,97 \pm 32,45$ & 49,29 & 7,43 & $<0,001^{*}$ \\
\hline
\end{tabular}

* diferença considerada estatisticamente significante 


\subsubsection{Associação dos testes do MN e do Cometa:}

A análise conjunta dos resultados observados no teste do $\mathrm{MN}$ e no teste Cometa do somente foi possível em 10 pacientes e 09 controles, conforme apresentado nas Tabelas 11 e 12 . Considerando os testes do MN e do Cometa juntamente, observou-se que os pacientes (P1 e P15) que apresentaram maior número de $\mathrm{MN}$ também apresentaram, pelo teste do Cometa, maior escore de danos basais (137 e 218, respectivamente), conforme apresentado na Tabela 11. O mesmo não foi observado em relação aos controles, em que o indivíduo C5, apesar de ter apresentado três $\mathrm{MN}$, não revelou nível elevado de danos nos linfócitos sem tratamento (Tabela 12).

Tabela 11: Sexo, idade e frequência de linfócitos binucleados com $\mathrm{MN}$ e de Cometas (dano basal sem tratamento) observada nos pacientes (P) com melanoma

\begin{tabular}{ccccc}
\hline Pacientes & sexo & Idade & MN & Cometa \\
\hline P1 & F & 57 & 3 & 137 \\
P3 & M & 57 & 2 & 28 \\
P4 & F & 54 & 0 & 18 \\
P5 & M & 52 & 0 & 38 \\
P6 & M & 59 & 1 & 19 \\
P12 & F & 49 & 0 & 17 \\
P13 & F & 46 & 0 & 75 \\
P14 & M & 55 & 2 & 42 \\
P15 & M & 48 & 3 & 218 \\
P16 & M & 38 & 1 & 196 \\
Média \pm dp & & $51,5 \pm 6,4$ & $1,2 \pm 1,2$ & $78,8 \pm 76,9$ \\
\hline
\end{tabular}

M: masculino, F: feminino; dp: desvio padrão 
Tabela 12: Sexo, idade e frequência de linfócitos binucleados com MN e de Cometas (dano basal sem tratamento) observada nos controles (C) sem melanoma

\begin{tabular}{ccccc}
\hline Controles & sexo & Idade & MN & Dano basal \\
\hline C3 & F & 57 & 1 & 42 \\
C5 & F & 51 & 3 & 42 \\
C7 & F & 51 & 0 & 18 \\
C9 & F & 38 & 0 & 16 \\
C11 & F & 51 & 0 & 45 \\
C13 & F & 52 & 0 & 32 \\
C14 & M & 40 & 0 & 36 \\
C15 & M & 53 & 0 & 31 \\
C16 & M & 44 & 1 & - \\
Média \pm dp & & $48,6 \pm 6,4$ & $0,6 \pm 1,0$ & $32,8 \pm 10,9$ \\
\hline
\end{tabular}

M: masculino, F: feminino; dp: desvio padrão

Conforme anteriormente mencionado, a comparação entre a frequência média de $\mathrm{MN}$ observada nos pacientes com melanoma $(1,2 \pm 1,2)$ e nos controles $(0,6 \pm 1,0)$ não foi estatisticamente significante $(p=0,23)$, o mesmo ocorrendo em relação ao teste do Cometa. A média de dano basal dos pacientes $(78,8 \pm 76,9)$ também não foi estatisticamente maior $(p=0,11)$ quando comparada com o grupo controle (32,8 $\pm 10,9)$, conforme apresentado nas Tabelas 11 e 12. 
5 DISCUSSÃO 


\subsection{Caracterização dos Grupos Estudados}

$\mathrm{Na}$ presente investigação, os pacientes com melanoma, diagnosticados em fase inicial da doença, apresentavam média de idade relativamente jovem $(50,6 \pm 6$ anos) em comparação a outros tipos de câncer. A amostra foi homogênea em relação ao gênero, apesar de estudos (Goodson e Grossman, 2009) relatarem uma maior incidência da doença no sexo masculino. Quanto às características fenotípicas, a cor de pele branca dos pacientes esteve associada com maior risco de melanoma e relatos de queimaduras de pele e vermelhidão.

A origem dos indivíduos parece influenciar na incidência, distribuição anatômica, tipo histológico e no prognóstico do melanoma, sendo a doença mais comum em caucasianos (Bakos et al., 2009). Nas regiões sudeste e sul do Brasil, em que há a predominância de caucasianos, a incidência do melanoma é cinco vezes maior em relação à incidência nas áreas próximas ao Equador. Indivíduos de coloração de pele mais clara produzem menos melanina, um fotoprotetor importante contra as radiações UV e são consequentemente mais sensíveis aos danos que estes raios podem induzir na epiderme (Brenner e Hearing, 2008, Thingnes et al., 2009).

Bakos e colaboradores (2009) sugeriram que a ascendência européia, principalmente italiana e alemã, parece ser um fator de risco ao melanoma 
na população da região sul do Brasil. A maior tendência em desenvolver a doença em pacientes com essas origens foi relacionada não apenas ao fototipo cutâneo mais claro, assim como também ao perfil genético característico desses povos. Um estudo realizado em 2009 por Chang e colaboradores, relacionou a exposição solar ao risco de melanoma e verificou-se a associação entre a sensibilidade à exposição solar com queimaduras e o desenvolvimento da doença. Diversos outros estudos também avaliaram a relação entre sensibilidade ao sol, fenótipo cutâneo, incidência de UV com o risco de melanoma, verificando uma associação positiva entre esses fatores (Loria e Matos, 2001, Fargnoli et al., 2004, Nikolaou et al., 2008, Chiarugi et al., 2009).

Quando o histórico familial de câncer foi considerado, $75 \%$ dos pacientes com melanoma tinham um membro da família próximo que teve algum tipo de câncer, sendo que quatro pacientes informaram ter um parente que também foi diagnosticado com melanoma. Aproximadamente $5 \%$ a $10 \%$ dos melanomas podem ter origem hereditária e estudos estão sendo realizados para identificar possíveis fatores genéticos com papel importante no risco ao melanoma visando utilizar essa informação no tratamento individual dos pacientes (Leachman et al., 2009). O risco de melanoma aumenta de 30 a 70 vezes em pessoas com história familial do melanoma em relação à população em geral (Santillan et al., 2009).

Na caracterização do tumor dos pacientes, aproximadamente $43 \%$ dos indivíduos apresentaram espessura do tumor $\leq 1,0 \mathrm{~mm}$ (Breslow I), ou seja, em estágios iniciais em que o tratamento recomendado foi remoção cirúrgica. 


\subsection{Avaliação Citogenética}

O melanoma, apesar de ser curável quando detectado em fase inicial, não possui um tratamento efetivo na fase metastática, pois é frequentemente resistente à terapia. Por isso, prever as respostas individuais à quimioterapia antes do tratamento pode ser uma estratégia importante para prevenir toxicidades desnecessárias com resultados duvidosos. Após o tratamento para o melanoma, uma resposta individual ao reparo dos danos causados pelo quimioterápico também pode alterar de forma significante o resultado esperado no tratamento.

O presente estudo avaliou os danos basais do DNA existentes em linfócitos de pacientes com e sem melanoma, por meio dos testes do $\mathrm{MN}$ e do Cometa e também avaliou a resposta in vitro da cisplatina, quimioterápico utilizado no tratamento do melanoma, e a resposta celular ao reparo após tratamento dos linfócitos, utilizando o teste do Cometa.

O teste do MN possibilita a avaliação de danos ao DNA que podem ter ocorrido há muitos anos atrás e que se mantém após divisões sucessivas da célula. Entretanto, não é um exame indicado para avaliação de reparo do DNA (Maluf, 2004). Por outro lado, o teste do Cometa que avalia dano recente ao DNA em uma única célula, como quebras de fita simples e dupla, identificação de sítios álcali-lábeis, assim como crosslinks que se formam no DNA, tem sido indicado também para avaliação do reparo do DNA (Burlinson et al., 2007). 
Na presente investigação, o teste do $\mathrm{MN}$ foi pesquisado somente na metade da amostra selecionada para o estudo do dano causado pela cisplatina e pelo reparo do DNA por questões técnicas de processamento de grande volume de amostras. Mesmo assim, consideramos que seria importante a inclusão de dois marcadores citogenéticos na avaliação de dano basal dos pacientes com melanoma e dos controles. As culturas realizadas a partir dos linfócitos de sangue periférico de 10 pacientes com melanoma e de 09 controles não revelaram diferenças estatisticamente significantes na frequência de $\mathrm{MN}$, apesar de um maior número de pacientes ter apresentado células com MN quando comparado com os controles.

A hipótese de associação entre a frequência de $M N$, em diferentes tecidos, como preditivo do risco de câncer encontra subsídios principalmente pelo fato de pacientes com câncer apresentarem maior frequência de $\mathrm{MN}$ quando comparados com controles (Duffaud et al., 1997, Murgia et al., 2008). Por outro lado, pacientes com síndromes de instabilidade cromossômica, como a Síndrome de Bloom e Fanconi, apresentam maior risco de câncer e incidência de MN, bem como indivíduos expostos a carcinógenos da classe I como benzeno, radiações ionizantes e tabaco (Maluf e Erdtmann, 2001, Mateuca et al., 2006, Eken et al., 2010, Kim et al., 2010).

Embora a avaliação da frequência de aberrações cromossômicas seja um marcador genético consistentemente associado ao risco aumentado de câncer (Boffetta et al., 2007), o teste do MN é um forte candidato para servir de biomarcador de exposição, uma vez que o mesmo pode ser aplicado em pesquisas de campo em um grande número de indivíduos (Bonassi et al., 2007). 
Pesquisas recentes que avaliaram mais de 6000 indivíduos, por um período de 20 anos, revelaram associação entre a frequência de $\mathrm{MN}$ e a incidência de câncer e mortalidade (Bonassi et al., 2007). Neste estudo os principais sítios de neoplasia foram de colo e reto, estômago, pulmão e mama.

Em um estudo recente de meta-análise (larmarcovai et al., 2008) pacientes já diagnosticados com diferentes tipos de câncer apresentaram frequência maior de $\mathrm{MN}$ em linfócitos de sangue periférico quando comparados com controles sem câncer, aumentando 1.45 vezes o risco da doença. Os autores verificaram que as frequências de MN por 1000 células analisadas variaram de 2,2 a 60,0 nos casos (média 20,3 \pm 0,4) e de 2,0 a 36,0 (média 14,8 \pm 0,3) nos controles.

$\mathrm{Na}$ presente avaliação, as frequências de MN por 1000 células analisadas variaram de 1 a 3 nos casos (média 1,2 \pm 1,2) e de 1 a 3 (média $0,6 \pm 1,0)$ nos controles embora essa diferença não tenha sido estatisticamente significante, provavelmente em decorrência do tamanho da amostra.

Aparentemente, não existem dados na literatura sobre a frequência aumentada de MN em linfócitos de pacientes com melanoma, no entanto, um estudo avaliou a frequência de $\mathrm{MN}$ em pacientes com melanoma metastático, após o tratamento com dacarbazina (Miele et al., 1998). Os autores verificaram um aumento na frequência de $M N$, em relação à frequência pré-tratamento, após 72 e 96 horas do tratamento, in vivo.

O teste do Cometa também foi utilizado em nosso estudo para avaliar a instabilidade cromossômica em linfócitos de sangue periférico de pacientes com melanoma e controles. Os resultados da análise do Cometa nos mesmos 
10 pacientes da amostra foram comparados com os resultados do MN. Embora a amostra tenha sido reduzida para comparações que permitam inferir diferenças estatisticamente significantes é interessante ressaltar que os pacientes que apresentaram um maior número de MN também apresentaram os maiores escores relativos aos danos no DNA pelo teste do Cometa. Se considerarmos que o teste do Cometa é uma técnica que detecta danos mais recentes ainda passíveis de reparo, enquanto que o $\mathrm{MN}$ detecta danos consolidados, a utilização de ambas as técnicas citogenéticas, em uma mesma população permite sugerir características da exposição, principalmente em estudos de monitoramento de populações expostas. Em circunstâncias específicas como, por exemplo, na exposição ocupacional, é importante considerar o risco de mutações desfavoráveis serem fixadas nas divisões celulares subsequentes (Maluf, 2004, Kopjar et al., 2009).

A exposição ocupacional no manuseio de drogas citotóxicas, entre elas a cisplatina, parece alterar a frequência de MN. Em um estudo realizado por Kopjar e colaboradores (2009) os autores verificaram que o manuseio de quimioterápicos, entre eles a cisplatina, por períodos que variaram de uma a seis horas por dia (média de 12,9 anos de exposição) revelaram um aumento na frequência de MN e de dano no DNA, pelo teste do Cometa, nos trabalhadores em comparação com o grupo controle. Os autores verificaram também que a frequência de $\mathrm{MN}$ era maior quanto maior o número de anos de exposição. Já em relação ao teste do Cometa, o tempo de exposição não foi significante, sendo que os danos de DNA nos trabalhadores foram similares (Kopjar et al., 2009). 
Embora o teste do Cometa identifique danos recentes ao DNA, o mesmo tem sido utilizado também na avaliação de populações com câncer. $\mathrm{Na}$ presente investigação, quando considerada a amostra total de 20 pacientes com melanoma, um nível maior de danos no DNA nos linfócitos foi observado quando comparados aos controles, apesar da diferença não ter sido considerada estatisticamente significante.

A correlação entre danos no DNA de linfócitos, com consequente formação de Cometas, e o risco de câncer vem sendo investigado na literatura ainda que os resultados não sejam ainda conclusivos (Smith et al., 2003, Lou et al., 2007). Alguns autores verificaram aumento significativo de Cometas em linfócitos de pacientes com diferentes tipos de câncer quando comparados com controles. Entre eles destacam-se o câncer de cabeça e pescoço (Palyvoda et al., 2003), mama (Kopjar et al., 2002, Smith et al., 2003), além de fígado e pulmão (McKenna et al., 2008). Nos referidos trabalhos, os autores verificaram que o escore médio para pacientes com câncer variou de aproximadamente 1,5 a 1,75 vezes maiores em relação ao dano nos indivíduos sem câncer (Palyvoda et al., 2003, Smith et al., 2003). É interessante ressaltar que nem todos fizeram avaliação visual do Cometa, tendo sido utilizado programas de análise de imagem para identificação inclusive de outros parâmetros como tamanho e intensidade da cauda (Djuzenova et al., 2006, Collins et al., 2008).

Em pelo menos uma investigação, a análise de $\mathrm{MN}$ e de Cometa foi feita em linfócitos de um mesmo grupo de pacientes com câncer e controles (Lou et al., 2007). Os resultados deste estudo revelaram que pacientes com 
câncer de pulmão apresentaram maior instabilidade cromossômica em relação aos controles, com frequências significantemente elevadas de $\mathrm{MN}$ e de Cometa, antes de qualquer tipo de tratamento.

Aparentemente, não existem dados sobre a frequência de Cometas em pacientes com melanoma, no entanto, a literatura relata estudos de avaliação da frequência de aberrações cromossômica em linfócitos e cultura in vitro de células tumorais destes pacientes (Balázs et al., 1999, Wiltshire et al., 2001, Rondón et al., 2009). Entre as aberrações numéricas relatadas, as mais comuns são a perda dos cromossomos 9 e 10, o ganho dos cromossomos $7,20,22$ e $X$ e menos frequentes, as aberrações estruturais dos cromossomos $7,9,11$ e 17. No cromossomo 9 está localizado o gene supressor de tumor CDKN2A, cuja mutação ou perda está relacionada a alguns cânceres. Deleções neste cromossomo parecem estar associadas com os estágios iniciais do melanoma (Rondón et al., 2009).

Os resultados obtidos por meio de testes como do MN e o Cometa devem sempre ser avaliados com cautela na correlação entre o agente e o efeito citogenético observado. Além de características individuais de cada genoma investigado, os hábitos pessoais, além da idade e do tipo de ocupação, podem interferir na análise final dos dados obtidos (Moller, 2006, Maluf, 2004, Lu e Morimoto, 2009).

Além disso, na presente avaliação o grupo de pacientes revelou hábitos e sensibilidade à exposição solar diferentes dos controles, que podem também ter contribuído para os resultados obtidos na análise citogenética, apesar dessa comparação não ter sido efetuada em decorrência do tamanho da amostra. 
Segundo Maluf (2004) e Moller (2006), a idade pode contribuir na frequência de mutações das células e o aumento do dano com o tempo talvez se deva à capacidade reduzida do reparo do DNA. Um estudo feito por Singh e colaboradores (1991) relatou aumento nos níveis de dano do DNA em linfócitos de indivíduos saudáveis, não fumantes, em decorrência da idade, após radiação ultravioleta. Foi observado um aumento tanto na frequência de MN como de Cometas nos indivíduos mais velhos, quando comparados aos mais jovens, sugerindo uma maior sensibilidade à radiação e deficiência no reparo.

Dentre os hábitos pessoais, aqueles que parecem mais influir na frequência de danos ao DNA são o consumo de bebidas alcoólicas e o hábito de fumar tabaco, situações que muitas vezes estão associadas. Estudos epidemiológicos indicam que o fumo parece aumentar o dano no DNA, uma vez que a combustão de compostos presentes no tabaco como, por exemplo, a nicotina e hidrocarbonetos policíclicos aromáticos podem se ligar ao DNA resultando em mutações com possível papel na carcinogênese (Piperakis et al., 1998, Maluf, 2004, Hoffman e Speit, 2005) Já em relação ao efeito do álcool, Lu e Morimoto (2009) associaram a formação de Cometas em linfócitos de sangue periférico com a quantidade de álcool consumida. É interessante ressaltar que a frequência de Cometas em alcoólicos foi menor do que a observada nos controles provavelmente em decorrência da formação de crosslinks do DNA com o acetaldeído, primeiro produto de metabolização do álcool. Esses resultados podem ter sido decorrentes da não utilização de um agente secundário, como por exemplo, 
o peróxido de hidrogênio, que possibilitasse a quebra dos crosslinks e consequentemente a identificação do dano (Lu e Morimoto, 2009).

$\mathrm{Na}$ presente investigação, os dois grupos estudados eram muito semelhantes em relação à idade e hábitos de consumo de álcool e tabaco, além da dieta e ocupação (dados não apresentados). A similaridade entre os grupos parece não ter influenciado as frequências de Cometa e de $\mathrm{MN}$ observadas.

Outra variável que pode interferir na frequência de $\mathrm{MN}$ e de Cometa, mas que não modificou os resultados encontrados na presente investigação é a ingestão de medicamentos, em especial uso de quimioterápicos em pacientes com câncer (Miele et al., 1998). Neste caso, os pacientes além de serem tratados com drogas capazes de causar danos severos no DNA, se possível a morte celular para impedir a divisão e propagação da mesma (com ou sem o dano gerado), parecem ter também uma resposta diferencial aos mecanismos de reparo (Braybrooke et al., 2000, Teixeira et al., 2009).

A capacidade de reparo reduzida e/ou deficiente dos pacientes com câncer pode ser uma das razões da maior frequência de Cometas. Pacientes com diferentes tipos de câncer, como melanoma, câncer de pulmão e de mama, parecem apresentar a frequência aumentada de Cometas em linfócitos de sangue periférico após tratamento com radioterapia ou quimioterápicos (Braybrooke et al., 2000, Lou et al., 2007, Teixeira et al., 2009). Por outro lado, os pacientes também parecem revelar habilidade reduzida das células em reparar o dano induzido pelos mesmos agentes genotóxicos (Kopjar et al., 2002, Sánchez-Suárez et al., 2008). 
Nadin e colaboradores (2006) avaliaram a resposta individual a dois agentes quimioterápicos, doxorrubicina e cisplatina, em linfócitos de pacientes com diferentes tipos de câncer, como de laringe, osteosarcoma, linfoma (antes e após a quimioterapia), e em indivíduos saudáveis (exposição in vitro aos quimioterápicos). Neste estudo foram avaliados os danos basais e o reparo do DNA, utilizando o teste do Cometa. Os autores observaram que pacientes com câncer apresentavam maior frequência de dano basal e dano no DNA após o tratamento com quimioterápicos. O reparo do DNA, avaliado após 24 horas, revelou que pacientes tratados com doxorrubicina não diferiram em relação aos controles pelo teste do Cometa. No entanto, quanto ao reparo da cisplatina, as diferenças foram estatisticamente significativas entre os grupos, sendo que a taxa de reparo observada nos pacientes foi inferior ao dos controles. Também foi observado nos pacientes tratados com cisplatina que vieram a falecer, que a migração do DNA no teste do Cometa foi inferior à média, sugerindo maior reparo do DNA, e provavelmente resistência ao tratamento.

Resultados semelhantes foram descritos por Smith e colaboradores (2003) quando avaliaram se o reparo deficiente do DNA contribuía para elevar o dano do DNA e consequentemente o processo de carcinogênese de mama. Os autores avaliaram, por meio do teste do Cometa, os linfócitos de pacientes com câncer de mama e indivíduos controles e observaram que o nível de dano basal era de aproximadamente 1,6 vezes maior que o dano nos controles. Após a irradiação dos linfócitos, o reparo do DNA foi avaliado e os resultados demonstraram uma capacidade de reparo inferior nos pacientes com câncer 
de mama. Eles concluíram que o elevado nível de dano no DNA está associado de maneira significante à maior suscetibilidade ao câncer de mama. Os autores sugeriram que pacientes com câncer de mama podem possuir um DNA mais frágil, sendo mais suscetíveis a mutações, associado a uma deficiência no reparo do DNA em células somáticas (Smith et al., 2003).

Em relação ao melanoma metastático, um estudo realizado por Braybrooke e colaboradores (2000), avaliou a resposta à dacarbazina e ao tamoxifeno, e a eficiência do reparo do DNA em 39 pacientes com esta neoplasia. Os autores observaram, pelo teste do Cometa, aumento do dano no DNA após os o tratamento quimioterápico e uma posterior diminuição no tamanho das caudas do Cometa, o que indicaria um provável mecanismo de reparo eficiente das células lesadas.

Algumas drogas quimioterápicas, como a cisplatina, formam adutos com o DNA, gerando os chamados crosslinks. Os crosslinks formados inibem fortemente a migração do DNA na eletroforese utilizada para identificação do Cometa. Como resultado, ocorre a formação de um DNA altamente condensado na "cabeça" do Cometa, com diminuição acentuada da "cauda". Esse formato gera um escore "normal", ou seja, um resultado falso negativo pela não identificação do dano gerado. Nesses casos, dependendo da droga que está sendo avaliada, é necessário o acréscimo na cultura de um agente secundário, como o peróxido de hidrogênio $\left(\mathrm{H}_{2} \mathrm{O}_{2}\right)$ ou a irradiação de raios-X. $\mathrm{O}$ agente secundário tem $\mathrm{o}$ papel de romper os crosslinks formados e permitir a migração do DNA lesado (Kosmider et al., 2005, Almeida et al., 2006). 
Na presente investigação avaliamos a resposta à cisplatina em linfócitos de pacientes com melanoma e de controles, após a adição de $\mathrm{H}_{2} \mathrm{O}_{2}$ de baixa molaridade e por um curto período de tempo para a visualização das caudas do Cometa, de acordo com o proposto na literatura (Blasiak et al., 2000).

$\mathrm{O} \mathrm{H}_{2} \mathrm{O}_{2}$ na concentração de $10 \mu \mathrm{M}$ não alterou de forma significante a frequência de danos no DNA nos linfócitos dos pacientes com melanoma embora essa diferença tenha sido significativa quando avaliado o grupo controle $(p<0,0001)$. Essa diferença observada no grupo controle pode ter sido decorrente da baixa incidência de danos observada nas culturas sem tratamento, pois quando comparada a frequência de Cometas após a adição de $\mathrm{H}_{2} \mathrm{O}_{2}$ no grupo com melanoma $(83,3 \pm 60,7)$ e no grupo controle $(78,6 \pm 24,5)$ a diferença não foi estatisticamente significante $(p=0,76)$.

No melanoma metastático, o tratamento quimioterápico inclui uma combinação de drogas, entre elas, a cisplatina, sendo a dose aplicada em torno de $20 \mathrm{mg} / \mathrm{m}^{2}$ (Papadopoulos et al., 2009). Diferentes concentrações de cisplatina foram utilizadas na presente investigação para avaliar a formação de Cometas após uma hora de tratamento, in vitro, com a droga. As concentrações de cisplatina foram escolhidas após testes de viabilidade realizados em nosso laboratório que revelaram 90\% de células íntegras (dados não apresentados). Essas concentrações foram também similares às descritas na literatura (Blasiak et al., 2000).

$\mathrm{Na}$ presente avaliação, após uma hora de tratamento com a cisplatina, o teste do Cometa revelou aumento no escore médio, nas três concentrações avaliadas $(10 \mu \mathrm{M}, 100 \mu \mathrm{M}$ e $250 \mu \mathrm{M})$, em relação ao escore 
médio obtido nas culturas sem tratamento (dano basal), ainda que essa diferença não tenha sido estatisticamente significante para os pacientes com melanoma. No grupo controle, a diferença entre o escore médio observado antes e após a adição de cisplatina foi considerada estatisticamente significante $(p<0,02)$ para as três concentrações de cisplatina avaliadas. Os indivíduos sem melanoma parecem ter uma resposta maior à ação da cisplatina quando os linfócitos são tratados in vitro. Possivelmente a instabilidade cromossômica observada nos pacientes com melanoma não permite a identificação do dano causado pela cisplatina. A análise de um número maior de pacientes diagnosticados com melanoma poderá auxiliar na avaliação dos resultados obtidos, uma vez que aparentemente, não existem dados da literatura da frequência de Cometas em relação a este tipo de paciente.

Embora o aumento do escore do Cometa, após o tratamento com a cisplatina, sugira uma resposta ao dano que a droga causa por meio da formação de adutos, na presente investigação os efeitos observados não foram dose-dependentes. Estudos como de Blasiak e colaboradores (2000) e de Kosmider e colaboradores (2005) avaliaram a cisplatina e outros quimioterápicos em linfócitos de indivíduos saudáveis e não fumantes, também utilizando o teste do Cometa. Diferentes concentrações das drogas foram testadas, no entanto, os autores observaram diminuição do tamanho da cauda dos Cometas com o aumento da concentração de cisplatina.

Os escores médios do Cometa, em decorrência do tempo de reparo, foram maiores no grupo controle em relação aos pacientes. Apesar dessa 
diferença não ter sido estatisticamente significante, a mesma parece indicar comportamentos diferentes no sistema de reparo que parece ser mais eficiente nos indivíduos sem câncer. Corrobora para esta hipótese o tamanho da cauda do Cometa que pode ter uma resposta diferencial no grupo controle sugerindo uma remoção mais eficiente dos adutos de cisplatina que foram formados.

Alguns dados na literatura parecem indicar que pacientes com melanoma possuem um sistema de reparo do DNA menos eficiente (Tomescu et al., 2001). Indivíduos com doenças genéticas, como xeroderma pigmentoso, apresentam acúmulo de mutações no DNA decorrente da falta de um mecanismo eficiente de reparo do DNA e maior suscetibilidade de desenvolver câncer de pele (Kauffmann et al., 2008). Recentemente foram descritos polimorfismos em genes de reparo do DNA que podem estar relacionados com o risco de desenvolvimento do melanoma como $X P C$, XPD, XPF, ERCC1, CSB, HR23B, XRCC1, XRCC2 e XRCC3, OGG1, APEX1 (Fargnoli et al., 2006).

Um estudo caso-controle realizado em nosso laboratório, com 193 pacientes com melanoma e 208 indivíduos controle, avaliou a contribuição de polimorfismos de genes de reparo do DNA (XRCC1/Mspl, XRCC3/Ncol e XPD/Pstl) no risco de melanoma. Os resultados relataram que uma associação entre os polimorfismos em pelo menos um dos alelos dos genes de reparo do DNA, XRCC1/Mspl e XPD/Pstl, aumenta em praticamente duas vezes o risco de desenvolver melanoma. O estudo também avaliou que, em relação à interação gene-meio ambiente, a falta 
de uso do filtro solar dobrou o risco de melanoma em indivíduos com polimorfismo XPD/Pstl. A pesquisa ressalta a importância da identificação de marcadores genéticos de suscetibilidade na prevenção contra esta doença (Gonçalves, 2009).

No estudo de Almeida e colaboradores (2006), cinco pacientes com câncer colorretal que estavam em tratamento de quimioterapia com a oxaliplatina, foram avaliados em relação à resposta a ação da droga e ao reparo do DNA. Os resultados foram comparados com as respostas dos testes em linhagens celulares tumorais tratadas, in vitro, com cisplatina e oxaliplatina. O teste do Cometa foi feito nos linfócitos dos pacientes e realizado em três momentos: antes do tratamento quimioterápico, logo após o tratamento e depois de 24 horas. O dano gerado pela oxaliplatina foi similar, no entanto, a eficiência de reparo do DNA entre os indivíduos variou. Enquanto um paciente não apresentou reparo algum após o tempo avaliado, outro paciente, nesse mesmo período apresentou $67 \%$ de reparo dos crosslinks formados. Numa primeira análise, poderíamos supor que o paciente que não teve reparo estaria respondendo bem ao tratamento, ao contrário do indivíduo que teve mais de $50 \%$ de reparo. Este tipo de resposta pode ajudar a escolha clínica do tratamento.

Já nas linhagens celulares tumorais tratadas in vitro, as concentrações das drogas avaliadas variaram de 50 a $500 \mu \mathrm{M}$ e o tempo de reparo de 4 a 72 horas. Após o tratamento de uma hora com as drogas, observou-se o aumento do tamanho da cauda do Cometa, de maneira dosedependente, assim como observado no presente estudo. Em relação ao 
reparo do DNA, considerando a concentração de $250 \mu \mathrm{M}$ de cisplatina, foi observado um aumento no tamanho da cauda até o período de 6 horas de reparo, e após esse tempo houve um decréscimo nas frequências de Cometas. Os autores justificaram esse aumento no tamanho das caudas pela remoção dos crosslinks formados em decorrência da droga e, após a retirada total do quimioterápico, o nível de danos começou a decrescer (Almeida et al., 2006).

Blasiak e colaboradores (2000) realizaram um trabalho semelhante ao desenvolvido neste estudo para avaliar o reparo do DNA, in vitro, em linfócitos de quatro indivíduos saudáveis, não fumantes. Os linfócitos foram tratados, in vitro, com três quimioterápicos, entre eles a cisplatina. As concentrações avaliadas nesse estudo foram de 1, 10, 100, 250 e 750 $\mu \mathrm{M}$ e o processo de reparo foi avaliado nos tempos de 30 minutos, 1,2 e 5 horas. Os autores verificaram que houve uma diminuição na frequência dos Cometas numa resposta dose-dependente, sendo que na maior concentração de cisplatina avaliada $(750 \mu \mathrm{M})$, o tamanho da cauda chegou a ser seis vezes menor em relação ao dano basal. Os autores justificam essa diminuição da cauda com o aumento da formação de crosslinks com o DNA, impedindo assim a migração do Cometa na corrida de eletroforese. Na avaliação do reparo do DNA, os resultados do estudo corroboraram com os nossos resultados, ou seja, com o aumento do tempo de reparo houve o aumento no tamanho da cauda dos Cometas, provavelmente em decorrência do mecanismo de reparo e remoção dos crosslinks formados. 
Os crosslinks cisplatina-DNA são removidos principalmente pela via de reparo por excisão de nucleotídeos (NER), um processo de várias etapas que envolve reconhecimento do dano, incisão e excisão de uma sequência de DNA que contém o dano, e reparo do DNA por meio de síntese de uma nova fita (Blasiak et al., 2000, Wang e Lippard, 2005, Leibeling et al., 2006). Essa deve ser uma das razões associadas ao maior tempo de reparo necessário para eliminação dos crosslinks.

O curto período de reparo utilizado em nosso estudo poderia explicar os resultados obtidos, uma vez que segundo alguns autores esse processo pode levar aproximadamente vinte e uma horas para que ocorra a remoção dos adutos cisplatina-DNA no sangue dos pacientes (Fichtinger-Schepman et al., 1990). Na presente investigação, consideramos que a exposição da célula a um tempo de reparo superior ao utilizado poderia acarretar aberrações decorrentes do tempo de cultura ou mesmo apoptose e morte celular. No entanto, experimentos com um tempo maior de reparo podem ser realizados para confirmação desta hipótese.

Enquanto as diferentes concentrações de cisplatina não interferiram na quantidade de dano do DNA, a resposta por meio do reparo parece ter sido ligeiramente maior ao longo do tempo. A relação entre o reparo de crosslinks induzidos pela cisplatina e a eficiência da quimioterapia tem uma importante implicação clínica na escolha dos agentes quimioterápicos para os indivíduos, pois potencializa a atividade antitumoral enquanto reduz toxicidades desnecessárias àqueles que provavelmente não se beneficiam do tratamento (Almeida et al., 2006). 
A formação de adutos cisplatina-DNA e o reparo do DNA em células tumorais não são os mesmos que nos linfócitos. Nadin e colaboradores (2006) relataram uma atividade maior de reparo por excisão de nucleotídeo em tecidos tumorais quando comparados aos linfócitos de pacientes resistentes à quimioterapia (agentes platínicos). No entanto, na tentativa de identificar pacientes resistentes à quimioterapia, os linfócitos foram considerados no presente estudo, como possíveis candidatos, para tal avaliação. Aparentemente, os resultados obtidos em linfócitos podem ser representativos do que ocorre no tecido alvo, embora isso não tenha sido ainda avaliado para diferentes tipos de tumores, inclusive o melanoma (Almeida et al., 2006).

Apesar de o melanoma cutâneo ser curável em estádio inicial, o prognóstico do melanoma avançado ainda é muito ruim devido à resistência a maioria dos agentes quimioterápicos. Dessa maneira, identificar alvos moleculares para o diagnóstico e tratamento dos pacientes é de extrema importância e tem sido o foco de pesquisas recentes sobre o melanoma.

No nosso estudo, no entanto, como não se pôde concluir que o mecanismo de reparo estava sendo eficiente, não foi possível inferir quais pacientes seriam resistentes a um tratamento quimioterápico com a cisplatina. Mais estudos deveriam ser desenvolvidos nesse sentido.

O teste do Cometa parece ser um biomarcador sensível para detectar dano basal e reparo do DNA em linfócitos de sangue periférico, sugerindo seu uso na prática clínica para identificação de resposta do paciente à quimioterapia. 
6 CONCLUSÕES 
Os resultados deste estudo permitiram concluir que:

a) não houve diferença entre os pacientes com melanoma e os controles quanto à frequência de danos basais tanto pelo teste do MN quanto pelo teste do Cometa.

b) Os linfócitos de pacientes com melanoma e dos controles revelaram resposta semelhante após a exposição, in vitro, à cisplatina aumentando de forma semelhante a frequência de Cometas, nas três concentrações estudadas de 10uM, 100uM e 250uM. Entretanto, quando o dano gerado foi comparado com o dano basal, este aumento foi estatisticamente significante somente para o grupo controle.

c) O processo de reparo in vitro (1h, 2,5h e $5 \mathrm{~h}$ ) aos danos no DNA causados pela exposição à cisplatina aumentou de forma significante a frequência de Cometas observada nos pacientes com melanoma e nos controles quando comparados com o dano basal identificado nas culturas sem tratamento. No entanto, a diferença na frequência de Cometas não foi estatisticamente significante entre os três tempos de reparo, em ambos os grupos.

d) $\mathrm{Na}$ avaliação do processo de reparo in vitro, verificamos que houve aumento significante na frequência de Cometas, após os 
três tempos de reparo, observada nos pacientes com melanoma e nos controles quando comparados com o dano causado pela cisplatina, considerando-se em conjunto as três concentrações da droga utilizadas.

e) Apesar dos resultados obtidos, devemos considerar que os estudos in vitro são indicativos de efeitos que podem ocorrer nos linfócitos e não nas células alvo, como no caso do melanoma. Entretanto, a identificação de marcadores de resposta a tratamentos com quimioterápicos, a partir de linfócitos de sangue periférico pode ser uma estratégia de pesquisa de fundamental importância na prática clínica. 
7 ANEXOS 


\section{ANEXO 1}

\section{QUESTIONÁRIO}

PROJETO: “Avaliação in vitro da cisplatina, em linfócitos de pacientes com melanoma cutâneo, por meio de testes citogenéticos”

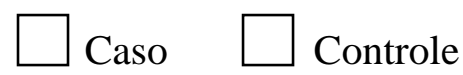

Data:

$$
\text { Reg. Proj.: }
$$

Data:

Reg. Lab.: Data:

Nome:

Data de nascimento:

Local Nascimento: ( )N ( )NE ( )CO ( )S ( )SE ( )SP capital ( )SP interior ( )outro país

Endereço:

n. ${ }^{\circ}$ : apto:

Bairro: Cidade: U.F.:

CEP: Telefone: (

Endereço: Bairro:

Telefone:

Observações:

Entrevistador: 


\section{INFORMACÕES GERAIS}

A1 Número do Registro:

A2 Data de nascimento: 1

idade:
A3 Sexo: ( )Masculino
( ) Feminino

A4 Qual o seu grau de escolaridade?

( ) não estudou

( ) $1^{\mathrm{a}}$ a $4^{\mathrm{a}}$ série

( ) $5^{\mathrm{a}}$ a $8^{\mathrm{a}}$ série

( ) colegial: ( )completo; ( ) incompleto

( ) superior: ( )completo; ( ) incompleto

A5 Qual a cor dos seus olhos?

castanho escuro
( ) azul
( ) verde
( ) castanho claro
( ) castanho

( ) outra:

A6 Quando você tinha 20 anos a cor natural dos seus cabelos era:
( ) loiro claro
( ) castanho claro
( ) loiro escuro
( ) castanho médio
( ) ruivo
( ) castanho avermelhado
( ) castanho escuro
( ) preto

A7 Como você classificaria a cor de sua pele:
( ) branca
( ) amarelo (oriental)
( ) pardo (mulato)
( ) negro
( ) não sei definir

Como você classificaria a cor de pele dos seus pais?

Pai: ( ) branca ( ) amarelo (oriental) ( ) pardo (mulato) ( ) negro

( ) não sei definir

Mãe: ( ) branca ( ) amarelo (oriental) ( ) pardo (mulato) ( ) negro ( ) não sei definir

A8 Qual seu estado civil?

( ) solteiro; ( ) casado; ( ) separado; ( ) vive junto; ( ) viúvo;

( ) outro

A9 Seus pais são parentes entre si?
( ) Não sei
( ) Não
( ) Sim
Tipo: 
A10 Você tem filhos?

Se sim, quantos?

com que idade(s):

A11 Quantos filhos?

Quantas filhas?

Possuem algum problema de saúde?

Você (mulher) ou sua companheira já sofreu algum aborto? （ )Não （ )Sim Se sim, quantos?

Provocado ou Espontâneo? Em qual período da gestação?

A12 Qual sua profissão (ocupação ou cargo que exerce)?

A13 Nesta ocupação, qual a jornada de trabalho?

( ) horário comercial (8-17hs)

( ) turno rodiziante

( ) diurno

( ) noturno

\section{INFORMACÕES SOBRE HÁBITOS}

\section{- $\quad$ TIPO DE DIETA}

B1 Quantas vezes por semana você come carne vermelha?

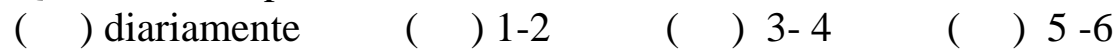

( ) nenhuma

B2 Quantas vezes por semana você come carne branca?
( ) diariamente
( ) $1-2$
( ) 3- 4
( ) $5-6$
( ) nenhuma

B3 Quantas vezes por semana você bebe leite ou come derivados do leite?
( ) diariamente
( ) $1-2$
( ) 3- 4
( ) $5-6$
( ) nenhuma

B4 Quantas vezes por semana você come verduras e legumes?

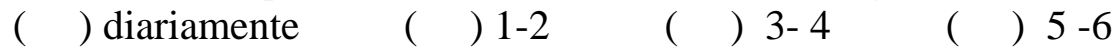

( ) nenhuma

B5 Quantas vezes por semana você come frutas?
( ) diariamente
( ) $1-2$
( ) 3- 4
( ) $5-6$
( ) nenhuma

B6 Existe algum tipo de alimento que você nunca ou raramente consome?
( ) Sim ( ) Não
Quais: 
B7 Quantas vezes por semana você come comida oriental (japonesa, chinesa )?

$\begin{array}{lllll}\text { ( ) diariamente ( ) 1-2 3-4 } & \text { ( ) } 5 \text {-6 }\end{array}$

( ) nenhuma

B8 Quantas vezes por semana você utiliza shoyu ou ajinomoto em suas refeições?
( ) diariamente
( ) $1-2$
( ) 3- 4
( ) $5-6$

( ) nenhuma

\section{- HÁBITOS DE BEBIDA}

B9 Você toma bebidas alcoólicas pelo menos 1 vez por mês?
( ) $\operatorname{sim}$
( ) não
( ) só no passado

B10 Quando é que você consome ou consumia bebidas alcoólicas?
( ) nas refeições
( ) entre as refeições
( ) ambos
( ) não consome

B11 Com que idade você começou a beber? anos ( ) não sei

( ) não bebo

B12 Se você bebia anteriormente, há quanto tempo está abstinente (meses)?

B13 Teve alguma fase na sua vida em que você bebeu mais?
( ) Sim
) Não
Não sei
Quando:
Tipo de bebida: 
B14 Assinalar com um $\mathbf{X}$ as opções de bebida ingeridas, indicando a frequência (média), a quantidade e o período em que você bebe ou bebeu as bebidas assinaladas.

Exemplo: se você toma 4 copos grandes ( $\underline{\mathrm{CG}}$ ) de cerveja diariamente e um copo médio $(\underline{\mathrm{CM}})$ de vinho, semanalmente, tomando os dois por um período médio de 10 anos em toda a sua vida, complete da seguinte forma:

\begin{tabular}{|l|c|c|c|c|c|c|c|c|}
\hline & \multirow{2}{*}{ Sim } & Não & \multicolumn{2}{|c|}{ Diariamente } & \multicolumn{2}{c|}{ Semanalmente } & \multicolumn{2}{c|}{ Mensalmente } \\
\cline { 4 - 8 } & quantidade & $\begin{array}{c}\text { Período } \\
\text { (anos) }\end{array}$ & quantidade & $\begin{array}{c}\text { Período } \\
\text { (anos) }\end{array}$ & quantidade & $\begin{array}{c}\text { Período } \\
\text { (anos) }\end{array}$ \\
\hline Cerveja & $\mathbf{X}$ & & 4CG & $\mathbf{1 0}$ & & & & \\
\hline $\begin{array}{l}\text { Bebidas } \\
\text { fermentadas } \\
\text { (vinho, licores) }\end{array}$ & $\mathbf{X}$ & & & & $\mathbf{1 C M}$ & $\mathbf{1 0}$ & & \\
\hline
\end{tabular}

\section{Considere em quantidade:}

Copo pequeno (cachaça/café): CP

Copo médio (refrigerante/chá): CM

Copo grande (cerveja): CG

Lata: LT

Garrafa: GF

\begin{tabular}{|c|c|c|c|c|c|c|c|c|}
\hline & \multirow{2}{*}{ Sim } & \multirow{2}{*}{ Não } & \multicolumn{2}{|c|}{ Diariamente } & \multicolumn{2}{|c|}{ Semanalmente } & \multicolumn{2}{|c|}{ Mensalmente } \\
\hline & & & quantidade & $\begin{array}{c}\text { Período } \\
\text { (anos) }\end{array}$ & quantidade & $\begin{array}{c}\text { Período } \\
\text { (anos) }\end{array}$ & quantidade & $\begin{array}{c}\text { Período } \\
\text { (anos) }\end{array}$ \\
\hline \multicolumn{9}{|l|}{ Cerveja } \\
\hline \multicolumn{9}{|l|}{\begin{tabular}{|l|} 
Bebidas \\
destiladas \\
(pinga, saquê, \\
uísque)
\end{tabular}} \\
\hline \multicolumn{9}{|l|}{$\begin{array}{l}\text { Bebidas } \\
\text { fermentadas } \\
\text { (vinho, } \\
\text { licores) }\end{array}$} \\
\hline \multicolumn{9}{|l|}{ Café } \\
\hline Chá & & & & & & & & \\
\hline
\end{tabular}


B15 Alguém de sua família ou amigos sugeriram que você deixasse de beber?
( ) Sim
( ) Não
( ) Não bebo

B16 Você já precisou ausentar-se do trabalho por problemas com bebida?
( ) Sim
( ) Não
( ) Não bebo

B17 Você já teve ou tem o hábito de beber pela manhã?
( ) Sim
( ) Não
( ) Não bebo

B18 Alguma vez sentiu necessidade de parar de beber?

( ) Sim ( ) Não ( ) Não bebo

\section{- HÁBITO DE FUMO}

B19 Você fuma ou fumou 1 cigarro diariamente, por pelo menos 1 ano?
( ) $\operatorname{sim}$
( ) nunca fumou
( ) somente no passado

Se você não fuma cigarro ou nunca fumou, passe para a questão $\underline{\mathbf{B 2 5}}$.

B20 Com que idade você começou a fumar?

( ) não sei

B21 Há quanto tempo você fuma? (meses/anos)

B22 Há quanto tempo você parou de fumar? (meses/anos)

B23 Qual a quantidade de cigarros por dia:

( ) 1-3 cigarros ( ) menos que $10 \quad$ ( ) 10 a $20 \quad$ ( ) mais que 20 cigarros

B24 Em média, durante quantos anos você realmente fumou? (não incluir períodos superiores há um mês que ficou sem fumar)

B25 Você fuma ou já fumou outro tipo de cigarro (de palha, cachimbo e charuto): Tipo:

Frequência:

B26 Você usa ou já usou algum tipo de drogas: （ ） não （ ） sim Tipo:

Frequência:

B27 Você vive junto com um fumante?

( ) Não ( ) Sim

B28 Você trabalha em lugar fechado onde as pessoas fumam?（） Não （） Sim 


\section{- $\quad$ HÁBITOS GERAIS}

B29 Você costuma realizar suas atividades de lazer e recreação (esportes, passeios, etc) ao ar livre, exposto ao sol? （ ） Não （ ） Sim

B30 Durante as férias de verão costuma ir à praia? ( ) Não ～～） Sim

\section{Questões sobre reação da sua pele ao sol, bronzeamento artificial e lâmpadas fluorescentes}

a) No verão, quando você fica exposto(a) ao sol do meio-dia por 1 hora poderia dizer que...

( ) não tenho muito risco de me queimar

( ) só me queimo após longa exposição ao sol forte

( ) me queimo se não ficar pouco tempo ao sol e se não usar proteção

( ) me queimo mesmo que fique ao sol por pouco tempo ou use proteção

b) Dois dias depois de ter ficado exposto(a) ao sol forte de verão, você poderia dizer que sua pele fica...

( ) muito escura, com um bronzeado intenso

( ) moderadamente bronzeada

( ) com um bronzeado leve e descascando

( ) sem qualquer bronzeado

c) Em relação à sensibilidade da sua pele quando exposta ao sol você poderia dizer que:

( ) sempre queima, nunca bronzeia

( ) sempre queima, depois bronzeia levemente e com dificuldade

( ) queima moderadamente e bronzeia gradual e uniformemente

( ) queima pouco, bronzeia bastante

( ) raramente queima, bronzeia intensamente

( ) nunca queima, bronzeia intensamente

B31 Alguma vez você já fez bronzeamento artificial? （ ） Não ～～） Sim

B32 Quando você se expõe ao sol, você utiliza filtro solar?
( ) a maioria das vezes
( )quase nunca
( ) às vezes
( ) nunca
( ) apenas nas primeiras horas

B33 Se você utiliza filtro solar, qual o Fator de Proteção Solar (FPS)?
( ) FPS menor que 15
( ) FPS 30
( ) FPS 15
( ) FPS igual ou maior que 50
( ) FPS 20

B34 Você tinge ou tingia o cabelo regularmente (mais de duas vezes por ano) (deconsiderar xampu colorante)? ( ) Não ( ) Sim 


\section{INFORMAC̄ÕES SOBRE SAÚDE}

C1 Você tem algum problema de saúde? （ ) Não （ ） Sim Especifique:

C2 Está tomando algum tipo de medicamento (incluindo vitaminas) por pelo menos 3 vezes por semana, por um período de um mês ou mais, com ou sem prescrição médica? ( ) Sim （） Não

Qual o tipo ou nome do medicamento em uso:

C3 Esteve exposto a algum tipo de raio-X (nos últimos 6 meses, excluindo os dentários)?

Tipo:
( ) Não
( ) Sim
( ) Não sei

C4 O(a) Sr(a) já teve algum tipo de câncer? （ ） Não （） Sim

Se sim, quais foram e que idade o(a) $\operatorname{Sr}(a)$ tinha quando foi diagnosticado?

Possui casos de câncer na família?

Qual seu grau de parentesco? (pais, irmãos, avós, bisavós, tios, primos, filhos)

\begin{tabular}{l|l}
\hline Grau de Parentesco & Tipo de Câncer \\
\hline & \\
\hline & \\
\hline & \\
\hline & \\
\hline
\end{tabular}

\section{OUTRAS INFORMACÕES}

D1 Em relação a produtos químicos/tóxicos, qual o grau de sua exposição durante suas atividades ocupacionais:

( ) grande parte da jornada diária (> $20 \mathrm{~h} / \mathrm{semana})$

( ) contato regular (5 a $19 \mathrm{~h} / \mathrm{semana})$

( ) contato ocasional (1 a $4 \mathrm{~h} / \mathrm{semana})$

( ) apenas raramente $(<1 \mathrm{~h} /$ semana) ou esporadicamente 
8 REFERÊNCIAS 
Almeida GM, Duarte TL, Steward WP, Jones GDD. Detection of oxaliplatininduced DNA crosslinks in vitro and in cancer patients using the alkaline comet assay. DNA Repair. 2006; 5: 219-225.

Andersson $\mathrm{M}$, Stenqvist $\mathrm{P}$, Hellmann B. Interindividual differences in initial DNA repair capacity when evaluating $\mathrm{H}_{2} \mathrm{O}_{2}$-induced DNA damage in extended-term cultures of human lymphocytes using the comet assay. Cell Biol Toxicol. 2007; 23(6):401-11.

Autrup H. Genetic polymorphisms in human xenobiotica metabolizing enzymes as susceptibility factors in toxic response. Mutat Res. 2000; 464(1): 65-76.

Bakos L, Masiero NC, Bakos RM, Burttet RM, Wagner MB, Benzano D. European ancestry and cutaneous melanoma in Southern Brazil. J Eur Acad Dermatol Venereol. 2009; 23(3):304-7.

Balázs $M$, Adám Z, Bégány A, Takruri AT, Adány R. Involvement of chromosome losses in the progression and metastasis formation of a human malignant melanoma. Cancer Genet Cytogenet. 1999; 109(2):114-8.

Balch CM, Soong SJ, Atkins MB, Buzaid AC, Cascinelli N, Coit DG, Fleming ID, Gershenwald JE, Houghton A Jr, Kirkwood JM, McMasters KM, Mihm MF, Morton DL, Reintgen DS, Ross MI, Sober A, Thompson JA, Thompson JF. An evidence-based staging system for cutaneous melanoma. CA Cancer J Clin. 2004; 54(3):131-49. 
Bendesky A, Michel A, Sordo M, Calderón-Aranda ES, Acosta-Saavedra LC, Salazar AM, Podoswa N, Ostrosky-Wegman P. DNA damage, oxidative mutagen sensitivity, and repair of oxidative DNA damage in nonmelanoma skin cancer patients. Environ Mol Mutagen. 2006; 47: 509-517.

Berra, CM, Menck CFM, Di Mascio P. Estresse oxidativo, lesões no genoma e processos de sinalização no controle do ciclo celular. Quím Nova. 2006; 29 (6):1340-1344.

Blankenburg S, König IR, Moessner R, Laspe P, Thoms KM, Krueger U, Khan SG, Westphal G, Berking C, Volkenandt M, Reich K, Neumann C, Ziegler A, Kraemer $\mathrm{KH}$, Emmert S. Assessment of 3 xeroderma pigmentosum group $\mathrm{C}$ gene polymorphisms and risk of cutaneous melanoma: a case-control study. Carcinogenesis. 2005; 26(6):1085-90.

Blasiak J, Kowalik J, Malecka-Panas E, Drzewoski J, Wojewódzka M. DNA damage and repair in human lymphocytes exposed to three anticancer platinum drugs. Teratog Carcinog Mutagen. 2000; 20:119-131.

Boffetta P, van der Hel O, Norppa H, Fabianova E, Fucic A, Gundy S, Lazutka J, Cebulska-Wasilewska A, Puskailerova D, Znaor A, Kelecsenyi Z, Kurtinaitis J, Rachtan J, Forni A, Vermeulen R, Bonassi S. Chromosomal aberrations and cancer risk: results of a cohort study from Central Europe. Am J Epidemiol. 2007;165(1):36-43.

Bonassi S, Znaor A, Ceppi M, Lando C, Chang WP, Holland N, KirschVolders M, Zeiger E, Ban S, Barale R, Bigatti MP, Bolognesi C, CebulskaWasilewska A, Fabianova E, Fucic A, Hagmar L, Joksic G, Martelli A, Migliore L, Mirkova E, Scarfi MR, Zijno A, Norppa H, Fenech M. An increased micronucleus frequency in peripheral blood lymphocytes predicts the risk of cancer in humans. Carcinogenesis. 2007; 28(3):625-31. 
Braybrooke JP, Houlbrook S, Crawley JE, Propper DJ, O'Byrne KJ, Stratford IJ, Harris AL, Shuker DE, Talbot DC. Evaluation of the alkaline comet assay and urinary 3-methyladenine excretion for monitoring DNA damage in melanoma patients treated with dacarbazine and tamoxifen. Cancer Chemother Pharmacol. 2000; 45(2):111-9.

Brenner M, Hearing VJ. The protective role of melanin against UV damage in human skin. Photochem Photobiol. 2008; 84(3):539-49.

Burlinson B, Tice RR, Speit G, Agurell E, Brendler-Schwaab SY, Collins AR, Escobar P, Honma M, Kumaravel TS, Nakajima M, Sasaki YF, Thybaud V, Uno Y, Vasquez M, Hartmann A. Fourth International Workgroup on Genotoxicity testing: results of the in vivo Comet assay workgroup. Mutat Res. 2007; 627(1):31-5.

Bussab WO, Morettin PA. Estatística Básica. São Paulo: Atual, 1987.

Cepeda V, Fuertes MA, Castilla J, Alonso C, Quevedo C, Pérez JM. Biochemical mechanisms of cisplatin cytotoxicity. Anticancer Agents Med Chem. 2007; 7(1):3-18.

Chang YM, Barrett JH, Bishop DT, Armstrong BK, Bataille V, Bergman W, Berwick M, Bracci PM, Elwood JM, Ernstoff MS, Gallagher RP, Green AC, Gruis NA, Holly EA, Ingvar C, Kanetsky PA, Karagas MR, Lee TK, Le Marchand L, Mackie RM, Olsson H, Østerlind A, Rebbeck TR, Sasieni P, Siskind V, Swerdlow AJ, Titus-Ernstoff L, Zens MS, Newton-Bishop JA. Sun exposure and melanoma risk at different latitudes: a pooled analysis of 5700 cases and 7216 controls. Int J Epidemiol. 2009; 38(3):814-30. 
Chiarugi A, Ceroti M, Palli D, Cevenini G, Guarrera M, Carli P. Sensitivity to ultraviolet $B$ is a risk factor for cutaneous melanoma in a Mediterranean population: results from an Italian case-control study. Clin Exp Dermatol. 2009; 34(1):8-15.

Chu G. Cellular responses to cisplatin. The roles of DNA-binding proteins and DNA repair. J Biol Chem. 1994; 269(2):787-90.

Collins A, Harrington V. Repair of oxidative DNA damage: assessing its contribution to cancer prevention. Mutagenesis. 2002; 17(6):489-93.

Collins AR. The comet assay for DNA damage and repair: principles, applications, and limitations. Mol Biotechnol. 2004; 26(3):249-61.

Collins AR, Oscoz AA, Brunborg G, Gaivão I, Giovannelli L, Kruszewski M, Smith CC, Stetina R. The comet assay: topical issues. Mutagenesis. 2008; 23(3):143-51.

Dadras SS, Asschenfeldt BL, Velasco P, Nguyen L, Vorá A, Muzikansky A, Jehnke K, Hauschild A, Hirakawa S, Mihn MC, Detmar M. Tumor lymphangiogenesis predicts melanoma metastasis to sentinel lymph nodes. Mod Pathol. 2005; 18:1-11.

Djuzenova CS, Mühl B, Fehn M, Oppitz U, Müller B, Flentje M. Radiosensitivity in breast cancer assessed by the Comet and micronucleus assays. Br J Cancer. 2006; 94(8):1194-203.

Duffaud F, Orsière T, Villani P, Pelissier AL, Volot F, Favre R, Botta A. Comparison between micronucleated lymphocyte rates observed in healthy subjects and cancer patients. Mutagenesis. 1997; 12(4):227-31. 
Eken A, Aydin A, Erdem O, Akay C, Sanal HT, Soykut B, Sayal A, Somuncu I. Cytogenetic analysis of peripheral blood lymphocytes of hospital staff occupationally exposed to low doses of ionizing radiation. Toxicol Ind Health. 2010. [Epub ahead of print]

Ellard S, Parry EM. A modified protocol for the cytochalasin B in vitro micronucleus assay using whole human blood or separated lymphocyte cultures. Mutagenesis. 1993; 8(4):317-20.

Elsendoorn TJ, Weijl NI, Mithoe S, Zwinderman AH, Van Dam F, De Zwart FA, Tates AD, Osanto S. Chemotherapy-induced chromosomal damage in peripheral blood lymphocytes of cancer patients supplemented with antioxidants or placebo. Mutat Res. 2001; 498: 145-158.

Fairbain DW, Olive PL, O’Neill KL. The comet assay: a comprehensive review. Mutat Res. 1995; 339:37-59.

Fargnoli MC, Piccolo D, Altobelli E, Formicone F, Chimenti S, Peris K. Constitutional and environmental risk factors for cutaneous melanoma in an Italian population. A case-control study. Melanoma Res. 2004; 14(2):151-7.

Fargnoli MC, Argenziano G, Zalaudek I, Peris K. High- and low-penetrance cutaneous melanoma susceptibility genes. Expert Rev Anticancer Ther. 2006; 6(5):657-70.

Faust F, Kassie F, Knasmüller S, Boedecker RH, Mann M, MerschSundermann V. The use of the alkaline comet assay with lymphocytes in human biomonitoring studies. Mutat Res. 2004; 566(3):209-29.

Fenech M. The advantages and disadvantages of the cytokinesis-block micronucleus method. Mutat Res. 1997; 392:11-18. 
Fenech M. The in vitro micronucleus technique. Mutat Res. 2000; 455(1-2):81-95.

Fenech M. Cytokinesis-block micronucleus assay evolves into a "cytome" assay of chromosomal instability, mitotic dysfunction and cell death. Mutat Res. 2006; 600(1-2):58-66.

Fichtinger-Schepman AM, van der Velde-Visser SD, van Dijk-Knijnenburg $\mathrm{HC}$, van Oosterom AT, Baan RA, Berends F. Kinetics of the formation and removal of cisplatin-DNA adducts in blood cells and tumor tissue of cancer patients receiving chemotherapy: comparison with in vitro adduct formation. Cancer Res. 1990; 50(24):7887-94.

Gamulin M, Kopjar N, Grgić M, Ramić S, Bisof V, Garaj-Vrhovac V. Genome damage in oropharyngeal cancer patients treated by radiotherapy. Croat Med J. 2008; 49(4):515-27.

Garcia-Sagredo. Fifty years of cytogenetics: a parallel view of the evolution of cytogenetics and genotoxicology. Biochimica et Biophysica Acta. 2008; 1779(6-7):363-75.

Gonçalves, FT. Genes de reparo do DNA e de susceptibilidade genética $m$ pacientes com melanoma maligno. São Paulo: FMUSP, 2009. Tese(Doutorado). Área de concentração: Patologia, Faculdade de Medicina da Universidade de São Paulo, São Paulo, SP, 2009.

Gontijo AMMC, Tice R. Teste do cometa para a detecção de dano no DNA e reparo em células individualizadas. In: Mutagênese Ambiental. Org: Ribeiro, L. R.; Salvadori, D. M. F.; Marques, E. K. Canoas: Ed. Ulbra, pp. 247-279, 2003.

Goodson AG, Grossman D. Strategies for early melanoma detection: Approaches to the patient with nevi. J Am Acad Dermatol. 2009; 60(5):719-35. 
Gray-Schopfer V, Wellbrock C, Marais R. Melanoma biology and new targeted therapy. Nature. 2007; 445(7130):851-7.

Grossman D, Altieri DC. Drug resistance in melanoma: mechanisms, apoptosis, and new potential therapeutic targets. Cancer Metastasis Rev. 2001; 20:3-11.

Heddle JA, Cimino MC, Hayashi M, Romagna F, Shelby MD, Tucker JD, Vanparys $\mathrm{PH}$, Macgregor JT. Micronuclei as an index of cytogenetic damage: Past, present and future. Environ Mol Mutagen. 1991; 18:277-291.

Heo MY, Kim SH, Yang HE, Lee SH, Jo BK, Kim HP. Protection against ultraviolet $B$ and $C$ induced DNA damage and skin carcinogenesis by the flowers of Prunus persica extract. Mutat Res. 2001; 496:47-59.

Hocker TL, Singh MK, Tsao H. Melanoma genetics and therapeutic approaches in the 21st century: moving from the benchside to the bedside. $J$ Invest Dermatol. 2008; 128(11):2575-95.

Hoffmann H, Speit G. Assessment of DNA damage in peripheral blood of heavy smokers with the comet assay and the micronucleus test. Mutat Res. 2005; 581(1-2):105-14.

Houtgraaf JH, Versmissen J, van der Giessen WJ. A concise review of DNA damage checkpoints and repair in mammalian cells. Cardiovasc Revasc Med. 2006; 7(3):165-72.

Hovhannisyan GG, Haroutunyan TS, Arutyunyan RM. Evaluation of cisplatinDNA crosslinks formation with UV-C application by the alkaline comet-assay. Exp Oncol. 2004; 26 (3):240-242. 
larmarcovai G, Ceppi M, Botta A, Orsière T, Bonassi S. Micronuclei frequency in peripheral blood lymphocytes of cancer patients: a metaanalysis. Mutat Res. 2008; 659(3):274-83.

INCA - Instituto Nacional de Câncer. Disponível em: <www.inca.gov.br>. Acesso em: 25 de novembro de 2009.

Jordan P, Carmo-Fonseca M. Molecular mechanisms involved in cisplatin cytotoxicity. Cell Mol Life Sci. 2000; 57(8-9):1229-35.

Karaman A, Binici DN, Kabalar ME, Calikuşu Z. Micronucleus analysis in patients with colorectal adenocarcinoma and colorectal polyps. World $\mathrm{J}$ Gastroenterol. 2008; 14(44):6835-9.

Kauffmann A, Rosselli F, Lazar V, Winnepenninckx V, Mansuet-Lupo A, Dessen P, van den Oord JJ, Spatz A, Sarasin A. High expression of DNA repair pathways is associated with metastasis in melanoma patients. Oncogene. 2008; 27(5):565-73.

Kim YJ, Choi JY, Cho YH, Woo HD, Chung HW. Micronucleus-centromere assay in workers occupationally exposed to low level of benzene. Hum Exp Toxicol. 2010; 29(5):343-50.

Kopjar N, Garaj-Vrhovac V, Milas I. Assessment of chemotherapy-induced DNA damage in peripheral blood leukocytes of cancer patients using the alkaline comet assay. Teratog Carcinog Mutagen. 2002; 22:13-30.

Kopjar N, Garaj-Vrhovac V, Kasuba V, Rozgaj R, Ramić S, Pavlica V, Zeljezić D. Assessment of genotoxic risks in Croatian health care workers occupationally exposed to cytotoxic drugs: a multi-biomarker approach. Int J Hyg Environ Health. 2009; 212(4):414-31. 
Kosmider B, Osiecka R, Zyner E, Ochocki J. Comparison between the genotoxicity of cis-Pt(II) complex of 3-aminoflavone and cis-DDP in lymphocytes evaluated by the comet assay. Drug Chem Toxicol. 2005; 28(2):231-44.

Landi MT, Baccarelli A, Tarone RE, Pesatori A, Tucker MA, Hedayati M, Grossman L. DNA repair, displasic nevi and sunlight sensitivity in the development of cutaneous malignant melanoma. J Natl Cancer Inst. 2002; 94 (2):94-101.

Leachman SA, Carucci J, Kohlmann W, Banks KC, Asgari MM, Bergman W, Bianchi-Scarrà G, Brentnall T, Bressac-de Paillerets B, Bruno W, CurielLewandrowski C, de Snoo FA, Debniak T, Demierre MF, Elder D, Goldstein AM, Grant-Kels J, Halpern AC, Ingvar C, Kefford RF, Lang J, MacKie RM, Mann GJ, Mueller K, Newton-Bishop J, Olsson H, Petersen GM, Puig S, Rigel D, Swetter SM, Tucker MA, Yakobson E, Zitelli JA, Tsao H. Selection criteria for genetic assessment of patients with familial melanoma. J Am Acad Dermatol. 2009; 61(4):677.e1-14.

Lee TK, Claridge E. Predictive power of irregular border shapes for malignant melanomas. Skin Res Technol. 2005; 11(1):1-8.

Leibeling D, Laspe P, Emmert S. Nucleotide excision repair and cancer. J Mol Histol. 2006; 37(5-7):225-38.

Liao W, McNutt MA, Zhu WG. The comet assay: a sensitive method for detecting DNA damage in individual cells. Methods. 2009; 48(1):46-53.

Loria D, Matos E. Risk factors for cutaneous melanoma: a case-control study in Argentina. Int J Dermatol. 2001; 40(2):108-14.

Lou J, He J, Zheng W, Jin L, Chen Z, Chen S, Lin Y, Xu S. Investigating the genetic instability in the peripheral lymphocytes of 36 untreated lung cancer patients with comet assay and micronucleus assay. Mutat Res. 2007; 617(1-2):104-10. 
Lu Y, Morimoto K. Is habitual alcohol drinking associated with reduced electrophoretic DNA migration in peripheral blood leukocytes from ALDH2-deficient male Japanese? Mutagenesis. 2009; 24(4):303-8.

Machado AT, Oliveira BRR, Pádua CAJ, Wainstein HAJA. Conduta para o Melanoma Cutâneo Maligno. Rev Med Minas Gerais. 2004; 14(3):173-179. MacKie RM. Malignant melanoma: clinical variants and prognostic indicators. Clin Exp Dermatol. 2000; 25:471-5.

Maddodi N, Setaluri V. Role of UV in cutaneous melanoma. Photochem Photobiol. 2008; 84(2):528-36.

Maluf SW, Erdtmann B. Genomic instability in Down syndrome and Fanconi anemia assessed by micronucleus analysis and single-cell gel electrophoresis. Cancer Genet Cytogenet. 2001; 124(1):71-5.

Maluf SW. Monitoring DNA damage following radiation exposure using cytokinesis-block micronucleus method and alkaline single-cell gel electrophoresis. Clin Chim Acta. 2004; 347(1-2):15-24.

Mariani G, Gipponi M, Moresco L, Villa G, Bartolomei M, Mazzarol G, Bagnara MC, Romanini A, Cafiero F, Paganelli G, Strauss HW. Radioguided sentinel lymph node biopsy in malignant cutaneous melanoma. J Nucl Med. 2002; 43(6):811-27.

Markovic SN, Erickson LA, Rao RD, Weenig RH, Pockaj BA, Bardia A, Vachon CM, Schild SE, McWilliams RR, Hand JL, Laman SD, Kottschade LA, Maples WJ, Pittelkow MR, Pulido JS, Cameron JD, Creagan ET; Melanoma Study Group of the Mayo Clinic Cancer Center. Malignant melanoma in the 21st century, part 1: epidemiology, risk factors, screening, prevention, and diagnosis. Mayo Clin Proc. 2007; 82(3):364-80. 
Marquette A, Bagot M, Bensussan A, Dumaz N. Recent discoveries in the genetics of melanoma and their therapeutic implications. Arch Immunol Ther Exp (Warsz). 2007; 55(6):363-72.

Marrot L, Meunier JR. Skin DNA photodamage and its biological consequences. J Am Acad Dermatol. 2008; 58(5 Suppl 2):S139-48.

Martin LP, Hamilton TC, Schilder RJ. Platinum resistance: the role of DNA repair pathways. Clin Cancer Res. 2008; 14(5):1291-5.

Mateuca R, Lombaert N, Aka PV, Decordier I, Kirsch-Volders M. Chromosomal changes: induction, detection methods and applicability in human biomonitoring. Biochimie. 2006; 88(11):1515-31.

McArt DG, McKerr G, Howard CV, Saetzler K, Wasson GR. Modelling the comet assay. Biochem Soc Trans. 2009; 37(Pt 4):914-7.

McKenna DJ, McKeown SR, McKelvey-Martin VJ. Potential use of the comet assay in the clinical management of cancer. Mutagenesis. 2008; 23(3):183-90.

Messadi M, Bessaid A, Taleb-Ahmed A. Extraction of specific parameters for skin tumour classification. J Med Eng Technol. 2009; 33(4):288-95.

Miele M, Bonassi S, Bonatti S, Martini E, Miglio L, Ottaggio L, Queirolo P, Sertoli M, Abbondandolo A. Micronucleus analysis in peripheral blood lymphocytes from melanoma patients treated with dacarbazine. Anticancer Res. 1998; 18(3B):1967-71.

Millikan RC, Hummer A, Begg C, Player J, Cotret AR, Winkel S, Mohrenweiser H, Thomas N, Armstrong B, Kricker A, Marrett LD, Gruber SB, Culver HD, Zanetti R, Gallagher RP, Dwyer T, Rebbeck TR, Busam K, From $\mathrm{L}$, Mujumdar $\mathrm{U}$, Berwick M. Polymorphisms in nucleotide excision repair genes and risk of multiple primary melanoma: the genes environment and melanoma study. Carcinogenesis. 2006; 27(3):610-618. 
Mohrenweiser HW, Jones IM. Variation in DNA repair is a factor in cancer susceptibility: a paradigm for the promises and perils of individual and population risk estimation? Mutat Res. 1998; 400: 14-23.

Moller $P$. The alkaline comet assay: towards validation in biomonitoring of DNA damaging exposures. Basic Clin Pharmacol Toxicol. 2006; 98(4):336-45.

Murgia E, Ballardin M, Bonassi S, Rossi AM, Barale R. Validation of micronuclei frequency in peripheral blood lymphocytes as early cancer risk biomarker in a nested case-control study. Mutat Res. 2008; 639(1-2):27-34.

Nadin SB, Vargas-Roig LM, Drago G, Ibarra J, Ciocca DR. DNA damage and repair in peripheral blood lymphocytes from healthy individuals and cancer patients: A pilot study on the implications in the clinical response to chemotherapy. Cancer Lett. 2006; 239: 84-97.

Nadin SB, Vargas-Roig LM, Drago G, Ibarra J, Ciocca DR. Hsp27, Hsp70 and mismatch repair proteins hMLH1 and hMSH2 expression in peripheral blood lymphocytes from healthy subjects and cancer patients. Cancer Lett. 2007; 252(1):131-46.

NCCN - National Comprehensive Cancer Network. Disponível em: <www.nccn.org/patients/patient_gls/_english/_melanoma/4_treatment.asp>. Acesso em: 28 de outubro de 2006.

Neter J, Kutner MH, Nachtsheim CJ, Wasserman W. Applied Linear Statistical Models. Illinois: Richard D Irwing, 1996.

Nikolaou VA, Sypsa V, Stefanaki I, Gogas H, Papadopoulos O, Polydorou D, Plaka M, Tsoutsos D, Dimou A, Mourtzoukou E, Korfitis V, Hatziolou E, Antoniou C, Hatzakis A, Katsambas A, Stratigos AJ. Risk associations of melanoma in a Southern European population: results of a case/control study. Cancer Causes Control. 2008; 19(7):671-9. 
Olive PL, Durand RE. Heterogeneity in DNA damage using the comet assay. Cytometry A. 2005; 66(1):1-8.

Östling O, Johanson KJ. Microelectrophoretic study of radiation-induced DNA damages in individual mammalian cells. Biochem Biophys Res Commun. 1984;123(1):291-8.

Palyvoda O, Polańska J, Wygoda A, Rzeszowska-Wolny J. DNA damage and repair in lymphocytes of normal individuals and cancer patients: studies by the comet assay and micronucleus tests. Acta Biochim Pol. 2003; 50(1):181-90.

Papadopoulos NE, Bedikian A, Ring S, Kim KB, Hwu WJ, Gerber DL, Homsi J, Hwu P. Phase I/II Study of a Cisplatin-Taxol-Dacarbazine Regimen in Metastatic Melanoma. Am J Clin Oncol. 2009; 32(5):509-514.

Perez RP. Cellular and molecular determinants of cisplatin resistance. Eur J Cancer. 1998; 34(10):1535-42.

Piperakis SM, Visvardis EE, Sagnou M, Tassiou AM. Effects of smoking and aging on oxidative DNA damage of human lymphocytes. Carcinogenesis. 1998; 19(4):695-8.

Rass K, Hassel JC. Chemotherapeutics, chemoresistance and the management of melanoma. G Ital Dermatol Venereol. 2009; 144(1):61-78.

Rigel DS. Cutaneous ultraviolet exposure and its relationship to the development of skin cancer. J Am Acad Dermatol. 2008; 58 (5 Suppl 2): S129-32.

Röckmann H, Schadendorf D. Drug resistance in human melanoma: mechanisms and therapeutic opportunities. Onkologie. 2003; 26: 581-587. 
Rondón S, Rangel N, Ramírez S. Cytogenetic study in peripheral blood of melanoma patients. Invest Clin. 2009; 50(2):173-86.

Rouse J, Jackson SP. Interfaces between the detection, signaling, and repair of DNA damage. Science. 2002; 297(5581):547-51.

Sánchez-Suárez P, Ostrosky-Wegman P, Gallegos-Hernández F, PeñarrojaFlores R, Toledo-García J, Bravo JL, Del Castillo ER, Benítez-Bribiesca L. DNA damage in peripheral blood lymphocytes in patients during combined chemotherapy for breast cancer. Mutat Res. 2008; 640(1-2):8-15.

Santillan AA, Cherpelis BS, Glass LF, Sondak VK. Management of familial melanoma and nonmelanoma skin cancer syndromes. Surg Oncol Clin N Am. 2009; 18(1):73-98.

Sarasin A, The molecular pathways of ultraviolet-induced carcinogenesis. Mutat Res. 1999; 428: 5-10.

Sarasin A, Kauffmann A. Overexpression of DNA repair genes is associated with metastasis: a new hypothesis. Mutat Res. 2008; 659(1-2):49-55.

Schmezer P, Rajaee-Behbahani N, Risch A, Thiel S, Rittgen W, Drings P, Dienemann H, Kayser KW, Schulz V, Bartsch H. Rapid screening assay for mutagen sensitivity and DNA repair capacity in human peripheral blood lymphocytes. Mutagenesis. 2001; 16(1):25-30.

She Z, Liu Y, Damatoa A. Combination of features from skin pattern and ABCD analysis for lesion classification. Skin Res Technol. 2007; 13(1):25-33.

Siddik ZH. Cisplatin: mode of cytotoxic action and molecular basis of resistance. Oncogene. 2003; 22(47):7265-79. 
Singh NP, McCoy MT, Tice RR, Schneider EL. A simple technique for quantitation of low levels of DNA damage in individual cells. Exp Cell Res. 1988; 175(1):184-91.

Singh NP, Danner DB, Tice RR, Pearson JD, Brant LJ, Morrell CH, Schneider EL. Basal DNA damage in individual human lymphocytes with age. Mutat Res. 1991; 256(1):1-6.

Slominski A, Wortsman W, Carlson AJ, Matsuoka LY, Balch CM, Mihm MC. Malignant Melanoma, An Update. Arch Pathol Lab Med. 2001; 125(10):1295-1306.

Smith TR, Miller MS, Lohman KK, Case LD, Hu JJ. DNA damage and breast cancer risk. Carcinogenesis. 2003; 24(5):883-9.

Stahl S, Bar-Meir E, Friedman E, Regev E, Orenstein A. Genetics in Melanoma. Isr Med Assoc J. 2004; (12):774-777.

Takahashi CS. Testes citogenéticos in vitro e aneuploidias. In: Mutagênese Ambiental. Org: Ribeiro LR, Salvadori DMF, Marques EK. Canoas: Ed. Ulbra, 355pp, 2003.

Teixeira AC, Dos Santos RA, Poersch A, Carrara HH, de Andrade JM, Takahashi CS. DNA repair in Etoposide-induced DNA damage in lymphocytes of breast cancer patients and healthy women. Int $\mathrm{J}$ Clin Exp Med. 2009; 2(3):280-8.

Thingnes J, Oyehaug L, Hovig E, Omholt SW. The mathematics of tanning. BMC Syst Biol. 2009; 3:60.

Tomescu D, Kavanagh G, Ha T, Campbell H, Melton D W. Nucleotide excision repair gene XPD polymorphisms and genetic predisposition to melanoma. Carcinogenesis. 2001; (3):403-408. 
Trimmer EE, Essigmann JM. Cisplatin. Essays in Biochemistry. 1999; $34: 191-211$.

Trzeciak AR, Barnes J, Evans MK. A modified alkaline comet assay for measuring DNA repair capacity in human populations. Radiat Res. 2008; 169(1):110-21.

Wang D, Lippard SJ. Cellular processing of platinum anticancer drugs. Nat Rev Drug Discov. 2005; 4(4):307-20.

Wang LE, Xiong P, Strom SS, Goldberg LH, Lee JE, Ross MI, Mansfield PF, Gershenwald JE, Prieto VG, Cormier JN, Duvic M, Clayman GL, Weber RS, Lippman SM, Amos CI, Spitz MR, Wei Q. In vitro sensitivity to ultraviolet B light and skin cancer risk: a case-control analysis. J Natl Cancer Inst. 2005; 97(24):1822-31.

Wei Q, Lee JE, Gershenwald JE, Ross MI, Mansfield PF, Strom SS, Wang LE, Guo Z, Qiao Y, Amos CI, Spitz MR, Duvic M. Repair of UV light-induced DNA damage and risk of cutaneous malignant melanoma. J Natl Cancer Inst. 2003; 95 (4):308-315.

Wei Z, Lifen J, Jiliang H, Jianlin L, Baohong W, Hongping D. Detecting DNA repair capacity of peripheral lymphocytes from cancer patients with UVC challenge test and bleomycin challenge test. Mutagenesis. 2005; 20(4):271-277.

Wiltshire RN, Dennis TR, Sondak VK, Meltzer PS, Trent JM. Application of molecular cytogenetic techniques in a case study of human cutaneous metastatic melanoma. Cancer Genet Cytogenet. 2001; 131(2):97-103.

Winsey SL, Haldar SA, Marsh HP, Bunce M, Marshall SE, Harris AL, Wojnarowska $\mathrm{F}$, Welsh $\mathrm{KI}$. A variant within the DNA repair gene XRCC3 is associated with the development of melanoma skin cancer. Cancer Res. 2000; 60 (20):5612-5616. 
Wozniak K, Blasiak K. Recognition and repair of DNA-cisplatin adducts. Acta Biochim Pol. 2002; 49(3):583-96.

Yu HP, Wang XL, Sun X, Su YH, Wang YH, Lu B, Shi LY, Xiong CI, Li YY, Li $\mathrm{F}, \mathrm{Xu} \mathrm{SQ}$. Polymorphisms in the DNA repair gene XPD and susceptibilidy to esophageal squamous cell carcinoma. Cancer Genet Cytogenet. 2004; 154:10-15.

Zamble DB, Lippard SJ. Cisplatin and DNA repair in cancer chemotherapy. Trends Biochem Sci. 1995; 20(10):435-9. 